Universidade de São Paulo

Escola de Comunicação e Artes

Departamento de Artes Cênicas

ANNA THERESA KÜHL

\title{
O traje social como disparador do traje de cena
}

São Paulo

2021 
ANNA THERESA KÜHL

O traje social como disparador do traje de cena

Dissertação

Dissertação apresentada ao Programa de PósGraduação em Artes, Área de Concentração: Teoria e Prática do Teatro, Linha de Pesquisa: História do Teatro, da Escola de Comunicação e Artes da Universidade de São Paulo, para obtenção do título de Mestra em Artes.

Orientador: Fausto Roberto Poço Viana

São Paulo 
Autorizo a reprodução e divulgação total ou parcial deste trabalho, por qualquer meio convencional ou eletrônico, para fins de estudo e pesquisa, desde que citada a fonte.

\section{Catalogação na Publicação}

Serviço de Biblioteca e Documentação

Escola de Comunicaçōes e Artes da Universidade de Sāo Paulo

Dados inseridos pelo(a) autor(a)

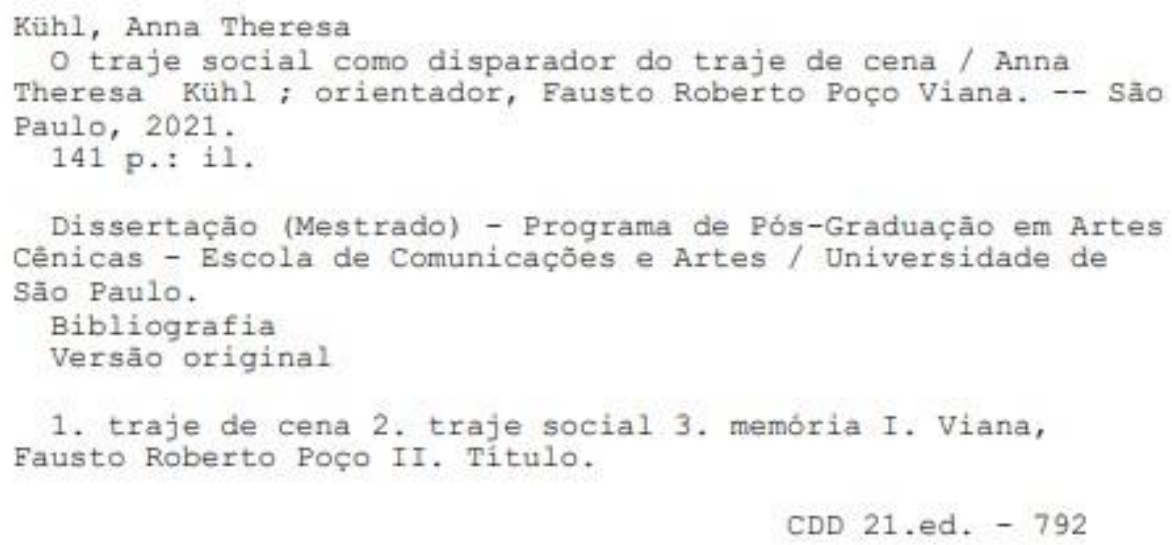


Nome: KÜHL, Anna Theresa

Título: O traje social como disparador do traje de cena

Dissertação apresentada à Escola de Comunicação e Artes da Universidade de São Paulo para obtenção do título de Mestra em Artes.

Aprovada em:

Banca Examinadora

Prof. Dr. Fausto Roberto Poço Viana

Instituição: CAC ECA USP

Julgamento:

Assinatura:

Profa. Dra.

Instituição:

Julgamento:

Assinatura:

Prof. Dr.

Instituição:

Julgamento

Assinatura:

São Paulo, de 2021 
Agradeço ao meu orientador Fausto Viana, pela parceria e paciência. E por nos empolgar sobre o assunto traje de cena em toda e qualquer oportunidade. Anotações insanas durante as aulas, o lápis não para.

Obrigada as minhas companheiras de jornada: Adriana, Cecília, Maria Eduarda, Paula, Celina. E Tainá, que me incentivou a prestar o mestrado, lá em 2017, e me deu a coragem de começar.

Meus companheiros de origem dos trabalhos acadêmicos nas artes, Laura, Gabriela, Maurício, Thiago, Flávia, Gustavo. Me instigaram amor pelo ofício, a caminhar até aqui. Ainda lá nesse começo, agradeço as queridas Kátia, Paula, Juliana, Larissa, Marta, Jaqueline, Malu.

Aline Barbosa, obrigada por nossa parceria, essa pesquisa tem muito dos nossos momentos de projetos e costuras.

Pelas trocas do projeto Memórias Vestidas, eu não poderia ser mais grata. Agradeço imensamente a todas as participantes do projeto onde cada aula, evento e encontro marcaram minha relação com o traje e a vida.

Agradeço a performer Beatriz Cruz, por trocar de roupa comigo, conversar sobre sua performance, e por ter registrado tão poeticamente cada uma de suas trocas.

E minha vida na arte não seria a mesma sem ter cruzado caminhos com as Matulas, com a rua Edna de Barros. Melissa Lopes, que leu com a maior paciência minhas primeiras versões de projeto. Alice, sempre com contribuições precisas e muito necessárias. Erika, sempre pronta a ajudar. O companheiro nas visualidades, Bruno Cardoso. As companheiras de luta e produção Cassiane, Quésia e Thaís.

Grande inspiração e mestra, Verônica Fabrini, que me cedeu tempo precioso para uma conversa deliciosa. 
Isabel Cristina Italiano e Patrícia Sant'anna, pelas presenças muito ilustres em minha qualificação. A inesquecível aula de história da moda com Patrícia também tem sua força na ideia dessa pesquisa.

A minhas irmãs maravilhosas, Emília e Lívia, por todos os figurinos que criamos para nós mesmas e nossas bonecas.

A Marta, minha mãe querida, quem cultivou em mim o amor pela leitura e pelos panos. Quem revisou pacientemente diversos textos e dirigiu até São Paulo comigo, muitas vezes.

Meu grande amor e companheiro, Antonio Carlos, com quem os dias brilham, por quem eu sinto que há sentido na vida. Sem você nada disso teria valor ou força. 


\section{RESUMO}

Esta pesquisa aborda elementos do traje social que podem funcionar como materiais disparadores e suporte para criação de trajes de cena. Tal investigação ocorre a partir da análise de projetos e experiências artísticas protagonizadas pelo traje social. Elencamos como estudos de caso três obras: a performance Descaracterizar-se, da artista Beatriz Cruz; o projeto de artes integradas Memórias Vestidas: Reconstrução Poética de Indumentária; e o espetáculo teatral Como se Fosse, do Grupo Matula Teatro, dirigido por Verônica Fabrini. Essa experiência prática de criação de traje de cena a partir do traje social dá corpo às premissas levantadas durante a pesquisa. São investigadas, com base neste recorte de material, relações possíveis entre traje social, memória, subjetividades e performatividade. Nossas principais referências teóricas são as definições sobre traje de Fausto Viana, investigações sobre performatividade de Josette Féral e Richard Schechner e as articulações sobre memória de Ecléa Bosi e Peter Stallybrass.

Palavras-chave: traje social, traje de cena, memória, performatividade 


\section{ABSTRACT}

This research adresses elements of social clothing that can work as material trigger and support to create scene costumes. Such investigation is conducted by analyzing several art projects and experiences where the social clothing is the main subject. We gathered here three art works to serve as case studies: the performance Descaracterizar-se ("Mischaracterize”), from Beatriz Cruz; the project of integrated arts Memórias Vestidas: Reconstrução Poética de Indumentária (“Dressed Memories: Poetical Reconstruction of Clothing”); and the theatrical performance Como se Fosse ("As if it were"), directed by Veronica Fabrini. This practical experiment in creating scene costumes based on social clothing subsidized the premises that arose during the research. Based on this material clipping, we investigate the possible relations among social clothing, memory, subjectivity and performativity. Our main theoretical references are the clothing definitions by Fausto Viana, investigations about performativity by Josette Féral and Richard Schechner and the essays about the memory of Eclea Bosi and Peter Stallybrass.

Key words: social clothing, scene clothing, memory, performativity 


\section{ÍNDICE DE FIGURAS}

Figura 1 - Série Fotográfica El Último Atuendo de los Desaparecidos. . 21

Figura 2 - Museu da Vida Cotidiana, exposição de 2015: Dust............. 23

Figura 3 - Willard Suitcases: Objetos da paciente Freda B. .................. 24

Figura 4 - Bispo do Rosário ............................................................... 25

Figura 5 - Imagem do projeto Clothes that survived Hiroshima............. 27

Figura 6 - Cena da série Chernobyl da HBO ....................................... 30

Figura 7 - Detalhe do trabalho Hygiene ............................................ 35

Figura 8 - Cartaz da Exposição Descaracterizar-se .............................. 39

Figura 9 - Vestindo a jaqueta masculina do participante Rodrigo.......... 45

Figura 10 - Censura da rede social .................................................. 48

Figura 11 - Roupas intimas no varal................................................ 49

Figura 12 - Cruz caracterizada como Drag Queen. .............................. 51

Figura 13 - A moda e o novo homem ............................................... 52

Figura 14 - Composição com trajes da participante Alda ....................... 55

Figura 15 - Composição das vestimentas e uso de órtese da participante

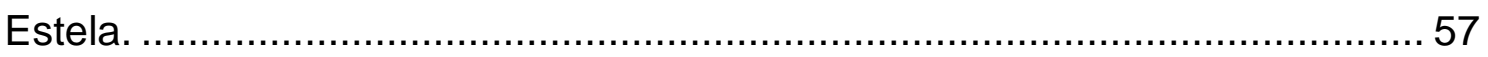

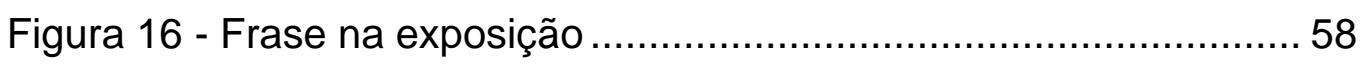

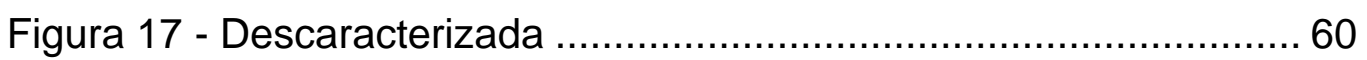

Figura 18 - Objetos trazidos pela participante Teresa .......................... 64

Figura 19 - A Oficina no SESC, em janeiro de 2016 ........................... 66

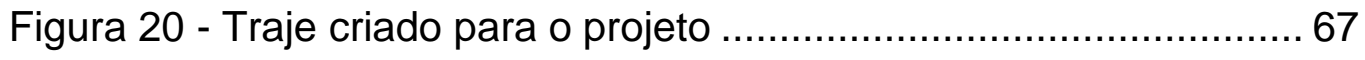

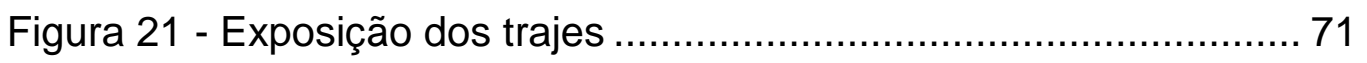

Figura 22 - Experimentos com retalhos durante aula do projeto ........... 72

Figura 23 - Registros das memórias.................................................. 73

Figura 24 - Painel exposto junto aos trajes......................................... 75

Figura 25 - O vestido de noiva de Maria............................................ 76

Figura 26 - Página do caderno de bordado ........................................ 78

Figura 27 - O bolero confeccionado por Teresa …………………...... 79

Figura 28 - Objetos durante exposição............................................... 80

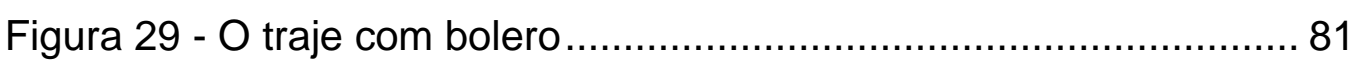

Figura 30 - Memórias do avô e da avó ................................................ 82 
Figura 31 - Filomena, memória escolhida pela participante 83

Figura 32 - O traje da participante 84

Figura 33 - Memórias de família 85

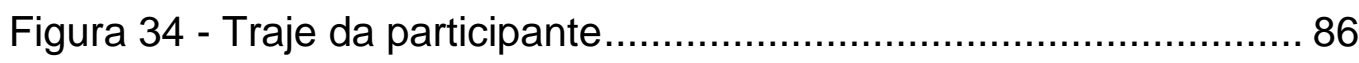

Figura 35 - Trajes de uma época não vivida....................................... 88

Figura 36 - Avesso e desbotamento ................................................. 90

Figura 37 - Fotos de infância ........................................................... 91

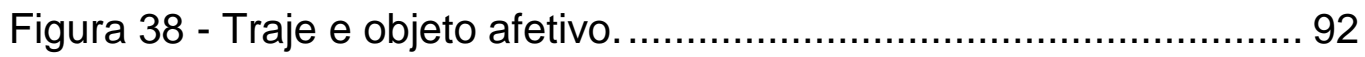

Figura 39 - Traje Celebração .......................................................... 93

Figura 40 - Trajes secam após tintura ………….............................. 96

Figura 41 - Croqui para Como se Fosse............................................. 97

Figura 42 - As atrizes em cena do espetáculo...................................... 99

Figura 43 - Traje bordado para o cenário ........................................... 100

Figura 44 - Objetos ligados ao universo da costura .......................... 104 


\section{SUMÁRIO}

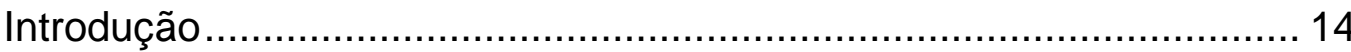

Capítulo 1 - A Roupa que sobrevive .................................................... 18

1.1 Biografia de objetos e uma arte que tem origem no cotidiano... 22

1.20 passado e a memória em oposição a novidade na moda...... 28

1.3 História da indumentária como apoio ao traje de cena............... 29

$1.4 \mathrm{O}$ traje de cena a partir do traje social - a que cena serve? ..... 31

1.5 Imaginário e bazar de objetos em Les Éphémères .................... 33

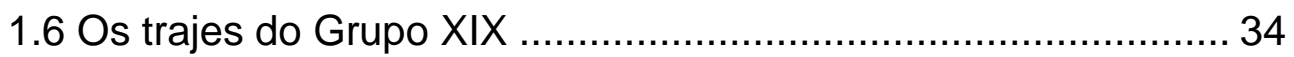

Capítulo 2 - Descaracterizar-se: infiltração das subjetividades............... 37

2.1 Trajetória e influências da performer ....................................... 40

2.2 Caminhar para desandar e (então) descaracterizar-se .............. 41

$2.3 \mathrm{O}$ gênero como ponto de partida ............................................. 44

2.4 Roupa interior e subjetividade ................................................. 48

2.5 Feminilidade exacerbada .................................................... 50

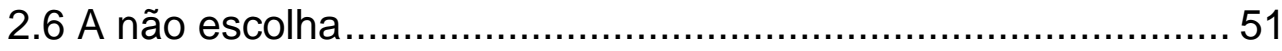

2.7 Uniforme como invisibilidade da subjetividade .......................... 53

2.8 Peças relevantes para troca ................................................... 56

2.9 Uma arqueologia da memória ............................................... 58

Capítulo 3 - Quando a criação de trajes encontra a memória................. 62

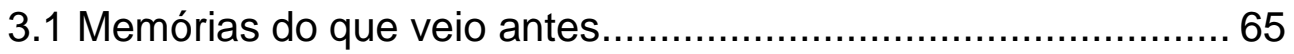

3.2 Oficina Histórias Da Moda: Identidade e Consumo Consciente.65

3.3 Costurando Histórias: Encontro de Gerações ........................... 67

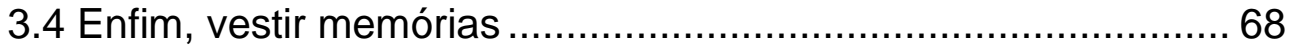

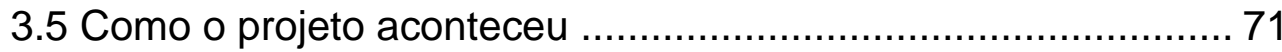

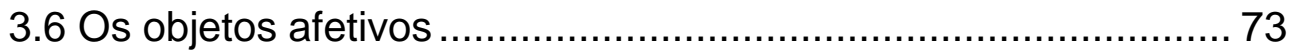


3.7 O processo de confecção e escolha das memórias 74

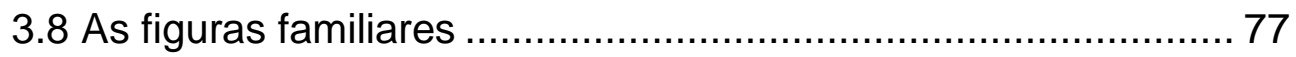

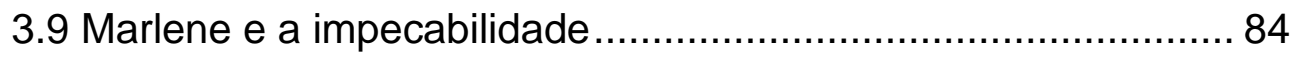

3.10 Pontos de contato entre o projeto e processos de criação de

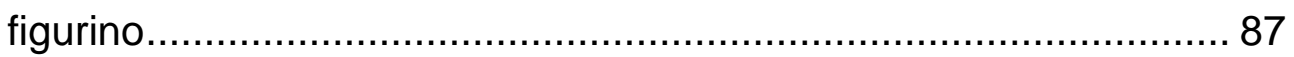

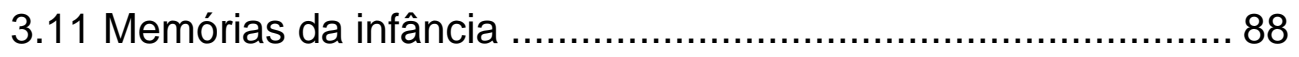

3.12 Celebração do traje como potência de vida............................. 91

Capítulo 4 - Para aquelas que não estão.............................................. 94

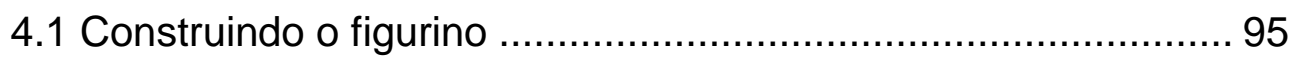

4.2 Imagens de homenagem e assombração …………………..... 98

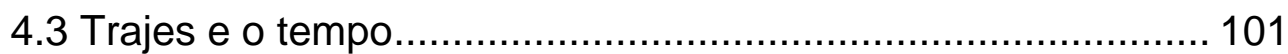

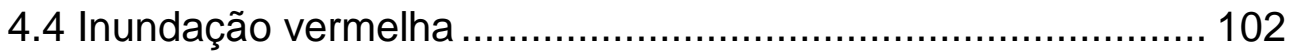

4.5 Presença das imagens da costura ......................................... 103

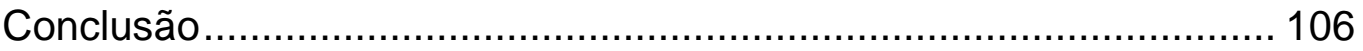

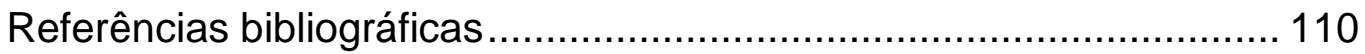

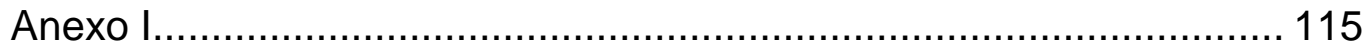

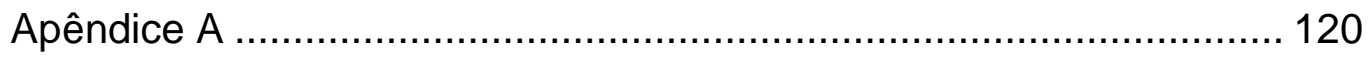

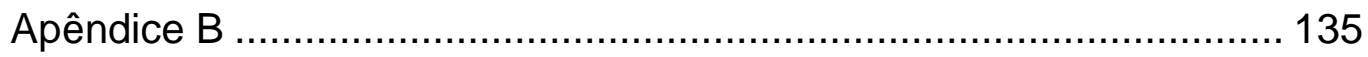




\section{Introdução}

Este texto e suas investigações nascem de uma gaveta cheia de botões de diversas roupas que muito provavelmente não existem mais. Nasce da troca de experiências pedagógicas, como aluna e como professora. Nasce da experiência como figurinista, ao transformar razões financeiras para uso da roupa de segunda mão em razões que dialogassem com a cena, sua estética e dramaturgia. Nasce, sobretudo, de uma busca poética e criativa.

Esse processo percorre um caminho onde roupas de segunda mão, ou seja, trajes sociais cotidianos, se tornam trajes de cena, ressignificados. E não apenas os trajes em si, materialmente, como também quando são apenas imagens e lembranças, disparadoras de recriações. Nesse caminhar, memórias, subjetividades e performatividades têm papéis fundamentais e muitas vezes andam juntas. Esta pesquisa se propõe a dar conta de alguns momentos e projetos onde esses termos se pronunciam em voz alta.

Ao longo da trajetória no ofício de figurinista, como aluna e docente, esta autora se deparou com a ideia que hoje pode ser considerada um clichê: a de que o traje pode contar histórias. Clichê, porém, imediatamente ligado a função do figurino, que existe para fazer parte de uma história, mesmo quando apresenta raízes documentais ou performáticas. Uma experiência arrematou algumas sensações sobre o tema, durante uma oficina em $2014^{1}$, com a artista húngara Juli Balazs, chamada "A reestruturação do traje baseada na reciclagem de roupas de segunda mão". Na oficina, Balazs orientava os participantes a seguirem premissas que ela havia experimentado antes em seu trabalho com as roupas de segunda mão. Ao final da experiência, nós, os participantes, concluímos que o curso oficializou como método de trabalho uma proposta que já executávamos desde crianças - ressignificar trajes, durante brincadeiras onde uma roupa, vestida de maneiras específicas, com adereços domésticos, podia significar um personagem, como uma princesa ou um mago, fazendo com que a criança vestida imaginasse que agora possuía as características daquela história. Muito além de qualquer conceito sobre reciclagem ou sustentabilidade,

\footnotetext{
1 A oficina foi ministrada no Centro de Formação Cultural Cidade Tiradentes e integrou a programação do Encontro Anual das Comissões de Educação, Performance Design e Pesquisa da OISTAT Brasil, em agosto de 2014. Disponível em https://www.annakuhl.com/2015/01/workshop-com-juli-balazs-curriculo.html, acesso em 24 fev. 2021.
} 
a oficina nos fazia pensar sobre como o traje já existente pode contar novas histórias, agora com um olhar artístico, recontextualizado por novas narrativas.

Esta experiência vai se refletir nos projetos da autora que se seguem, entre eles, Memórias Vestidas: Recriação de Indumentária, que também foi um dos pontos de partida dessa pesquisa. A partir daquele momento, se relacionar com roupas de segunda mão convocava a perspectiva de que o traje poderia ser um objeto disparador de uma narrativa, para além de reproduzir um contexto.

O têxtil e os trajes podem nos provocar diversas sensações, nos encantar, fascinar e até mesmo nos assombrar. Uma relação ao alcance de todos nós, "(...) qualquer coisa que a pessoa conhece, vive e vive no cotidiano" (BRAZ, in VIANA, 2015, p. 77), algo que todos sabemos o que é, mais mundano (quase) impossível, e, ao mesmo tempo, com um enorme potencial de impacto por carregar tantas memórias e sensações que emergem de baús e caixas de costura, de roupas penduradas nos cabides dos bazares e dos acervos. Experimentamos esse tom esmaecido das roupas esquecidas ao mesmo tempo que somos surpreendidos por sensações frescas que ainda não haviam sido notadas.

A partir de um levantamento bibliográfico, elencamos alguns termos que nos são caros. A começar por dois termos chave, traje social e traje de cena, ambos integrantes da categoria do traje civil, que "cobria vasta quantidade de trajes de uso cotidiano dos civis" (VIANA, 2017, p. 47). Importante notar que o traje civil não é uma mera distinção do traje militar, incluindo também o traje regional, o profissional, interior ou íntimo, entre outros.

O traje social vai abranger tanto as roupas de dia santo ${ }^{2}$, usadas em ocasiões consideradas especiais, como eventos e festas; quanto "roupas usadas pelos civis no dia a dia" (Ibidem p. 48), trajes ordinários e triviais do cidadão comum. Já o traje de cena, também chamado de figurino, é "a indumentária das artes cênicas. Mais amplo que traje teatral, pode abranger trajes de teatro, cinema, dança, circo, mímica e performance" (Idem). Em certo momento, a autora observa precisão no termo traje de cena, uma vez que se refere a um traje que se encontra em cena, sendo assim um termo simples e direto.

\footnotetext{
${ }^{2}$ Expressão popular, comum no interior do estado de São Paulo, se refere ao traje de ocasiões especiais, geralmente menos usados, para que não se gastem e durem mais.
} 
Partimos de noções sobre performatividade presentes nas obras de Josette Féral, Silvia Fernandes e Eleonora Fabião, alinhadas a estudos sobre performance, em oposição a teatralidade; ou ainda em Richard Schechner, que também alinha o termo performance a ações de comportamento.

Quando nos referimos a memória, falamos da percepção do tempo, algo subjetivo, que vamos relacionar a narrativas pessoais, para além do tempo histórico. A memória diz respeito ao tempo cíclico, cotidiano, que se repete, mas também ao tempo do passado, registrado. Segundo Jacques Le Goff "o tempo histórico encontra, num nível muito sofisticado, o velho tempo da memória, que atravessa a história e a alimenta" (1990, p. 13). Falando em memória, nos guiamos principalmente por elaborações de Ecléa Bosi, onde a memória faz parte de uma percepção concreta de mundo que se vale de um passado que de algum modo se conservou; uma reserva crescente a cada instante que dispõe da totalidade da nossa experiência adquirida. Nesse sentido, o traje nos ajuda a marcar o tempo - tanto épocas mais distantes, históricas, quanto um tempo cotidiano, onde nosso dia a dia se manifesta nos trajes sociais escolhidos para cada comportamento performado. Também nos guiamos por elaborações de Peter Stallybrass sobre as roupas e suas relações com quem está de posse delas, ou quais memórias elas podem emanar.

Nosso vestuário se relaciona com a construção social da identidade do indivíduo, e isso se reflete na relação traçada entre ator/performer e o traje de cena. Julgamos existirem inúmeras maneiras de o traje social ser disparador do traje de cena, e nesta dissertação, discorreremos sobre alguns contextos em que ocorre esta tradução.

No primeiro capítulo, elencaremos alguns contextos artísticos onde podemos ver ressignificações de objetos do cotidiano. Em tais momentos, artefatos podem mudar de status e integrar obras artísticas, entre eles, objetos têxteis e o traje social.

No segundo capítulo, observamos uma maneira de acessar memórias e subjetividades por meio do uso do traje social em si, a partir da obra Descaracterizar-se, onde a roupa é o enunciado da performance, fazendo do traje social o traje de cena ou traje da performance. Esta obra investiga subjetividades e papéis sociais exercidos pelas roupas cedidas voluntariamente 
por pessoas que participam da performance, bem como registra essas ações em fotografias e depoimentos, publicados rotineiramente em uma rede social.

Abordamos no terceiro capítulo dessa dissertação um projeto de artes integradas onde acontece uma recriação poética de indumentária, o projeto Memórias Vestidas, que como bem coloca a jornalista Paula Guerreiro, o nome "aponta, poeticamente, para seu objetivo: vestir memórias"3. O projeto não produziu trajes para alguma cena de teatro ou cinema, mas teve como produto uma exposição com fotografias dos trajes, depoimentos e um desfile, protagonizado pelas integrantes vestindo os trajes que elas próprias recriaram. O processo do projeto teve pontos de contato com a criação de trajes de cena, com processos similares e poéticos. O projeto como foi enviado ao edital que o contemplou se encontra no anexo I.

Notamos que um quarto capítulo, a partir de uma experiencia prática da autora, seria uma boa soma. Nesse último capítulo, nos debruçamos sobre o processo de criação dos trajes de cena do espetáculo teatral Como se Fosse, onde figurino e cenário são criados a partir de trajes sociais.

Nos parece relevante sublinhar que muitas das fontes empregadas no trabalho tem origem em documentos virtuais ou acervo próprio, ainda não publicadas formalmente. Essa dissertação é inclusive uma maneira de organizar e disponibilizar tais documentos de maneira acadêmica, para posterior consulta. Sendo docente, a autora espera colaborar com a bibliografia e conteúdo disponíveis sobre o tema, que venham a servir para futuros trabalhos, alunos e interessados.

Concluímos a partir das reflexões levantadas ao longo da pesquisa, fazendo das considerações finais um arremate, após detalhar elementos cotidianos que disparam aspectos artísticos interessantes.

Nas páginas seguintes, olhamos para avessos dos estudos de caso, quando o traje social dispara possibilidades de trajes de cena. Esperamos costurar relações entre o efêmero da arte e o traje que sobrevive.

\footnotetext{
3 Trecho extraído do release de imprensa do projeto, produzido pela jornalista e pesquisadora Paula Mathenhauer Guerreiro, 2016.
} 
Capítulo 1 - A Roupa que sobrevive

A coroa sobreviveu à cabeça A mão perdeu para a luva. A bota direita derrotou a perna. Quanto a mim, vou vivendo, acreditem. Minha competição com o vestido continua.

E que teimosia a dele! E como ele adoraria sobreviver! (Wislawa Szymborska, poemas) 
O traje pode ser uma maneira de lembrar, de construir memórias, uma forma de sobreviver, de evitar o esquecimento. A roupa é algo muito próximo de nossos corpos, está sobre a nossa pele, e talvez por isso seja tão impactante e impossível separar do cotidiano: o ato de vestir é uma experiência comum a todos, que faz parte da nossa cultura, e por isso mesmo, a reflete.

Conforme colocado por Peter Stallybras (2012, p. 11), "a roupa dura, mas é mortal". Quando a roupa é representada em uma pintura, fotografia, ou mesmo quando trata-se de um traje de cena, torna-se um documento para além da expressão artística da qual faz parte, pode tornar-se elemento de construção de identidade. Rita Morais de Andrade (2008, p. 19) diz que "a roupa é uma maneira de dar e fazer sentido do mundo". Além do traje ser suporte para a expressão de memórias e subjetividades, é um documento que pode persistir, uma herança palpável que está ao nosso alcance - podemos moldá-lo, algo que outro objeto, como por exemplo, uma joia de família, não permite. Trajes sociais de indivíduos comuns, que envolvem o corpo ordinário, podem ser conservados por consequência do sentimento afetivo, pela curiosidade antropológica, pelo estudo forense, talvez tornando-se um documento histórico. Muitas vezes os trajes que se conservam foram especiais de alguma forma: roupas de dia santo, peças de enxoval, vestidos de noiva, trajes de formatura etc. Esses trajes que não eram ordinários podem ter ficado de herança, recebido cuidados ou terem sido de pouco uso; por isso se conservaram melhor. Os trajes sociais do dia a dia talvez se conservem com um pouco mais de dificuldade, as vezes em um estado mais precário, como observado durante atuação profissional da autora em constantes visitas à bazares, brechós e acervos em busca de peças para figurinos.

Quando trajes ordinários sobrevivem ${ }^{4}$, podem sim, fazer parte de acervos particulares ou museológicos, considerados e conservados como fontes históricas, determinadas sob alguma curadoria, que ajudam a definir o que merece ser guardado como documento ${ }^{5}$. Muito do acervo presente em museus que possuem coleções de indumentária, tais como o Victoria and Albert ou o Costume Institute, ligado ao Metropolitan Museum of Art de Nova York, foram

\footnotetext{
4 Algumas ideias aqui apresentadas revisadas e complementadas foram desenvolvidas inicialmente no artigo A roupa que sobrevive: memórias, traje social e traje de cena; publicado no $15^{\circ}$ Colóquio de Moda.

${ }_{5}^{5}$ Para Le Goff (1990), o documento é um material da memória, de uso dos historiadores.
} 
construídos a partir de doações da burguesia (ANDRADE, 2008, p. 81), com ênfase nos designers de grandes centros de moda europeus e norteamericanos. De certa forma doar trajes assinados por couturiers podia ser considerado uma honra, um privilégio fora do alcance de populares. Quando falamos do cidadão comum, estamos nos referindo à classe trabalhadora, que começa a expressar subjetividades e distinções conforme a moda é democratizada e popularizada, a partir do final do século XIX e durante o século $X X$, o que torna possível certo esforço para parecer distinto, algo que antes era exclusivo das classes mais altas (SVENDSEN, 2010). Podemos observar a história da moda como uma história dos trajes das elites até certo momento histórico por terem sobrevivido em maior amostragem na forma de documentos.

É possível perceber diversos atravessamentos entre traje, performatividade e memória, trazidos pela materialidade destes objetos da indumentária e suas biografias. O traje social ordinário, com todas as suas subdivisões, muitas vezes não sobrevive como objeto, mas costuma estar presente como memória ou imagens que talvez integrem arquivos desordenados, que se multiplicam exponencialmente. A roupa de bater ${ }^{6}$, por mais querida que tenha sido, se perde mais facilmente, porém sobrevive na memória. Os vestidos-surrados-de-algodão-de-florzinha geralmente se perdem; o vestido fino, ganhado da prima rica, tem uma chance maior de sobreviver.

O traje funerário traduz como nunca a ideia da roupa que sobrevive, conforme visto em Stallybrass "os corpos vêm e vão: as roupas que receberam estes corpos sobrevivem" (2012, p. 11). Em investigações forenses, o reconhecimento de identidades pode se dar por meio dos trajes, como vemos na série fotográfica de Fred Ramos (2014) El Último Atuendo de los Desaparecidos, composta pelos trajes usados por jovens assassinados no contexto violento do narcotráfico em El Salvador, como vemos na figura 1. Nesta série somos apresentados à tragédia desses jovens e observamos através da fotografia 0 impacto daquilo que o traje social tem a nos contar.

${ }^{6}$ Expressão popular para roupas do cotidiano, que podem ser gastas com maior frequência. 
Figura 1 - Série Fotográfica El Último Atuendo de los Desaparecidos.
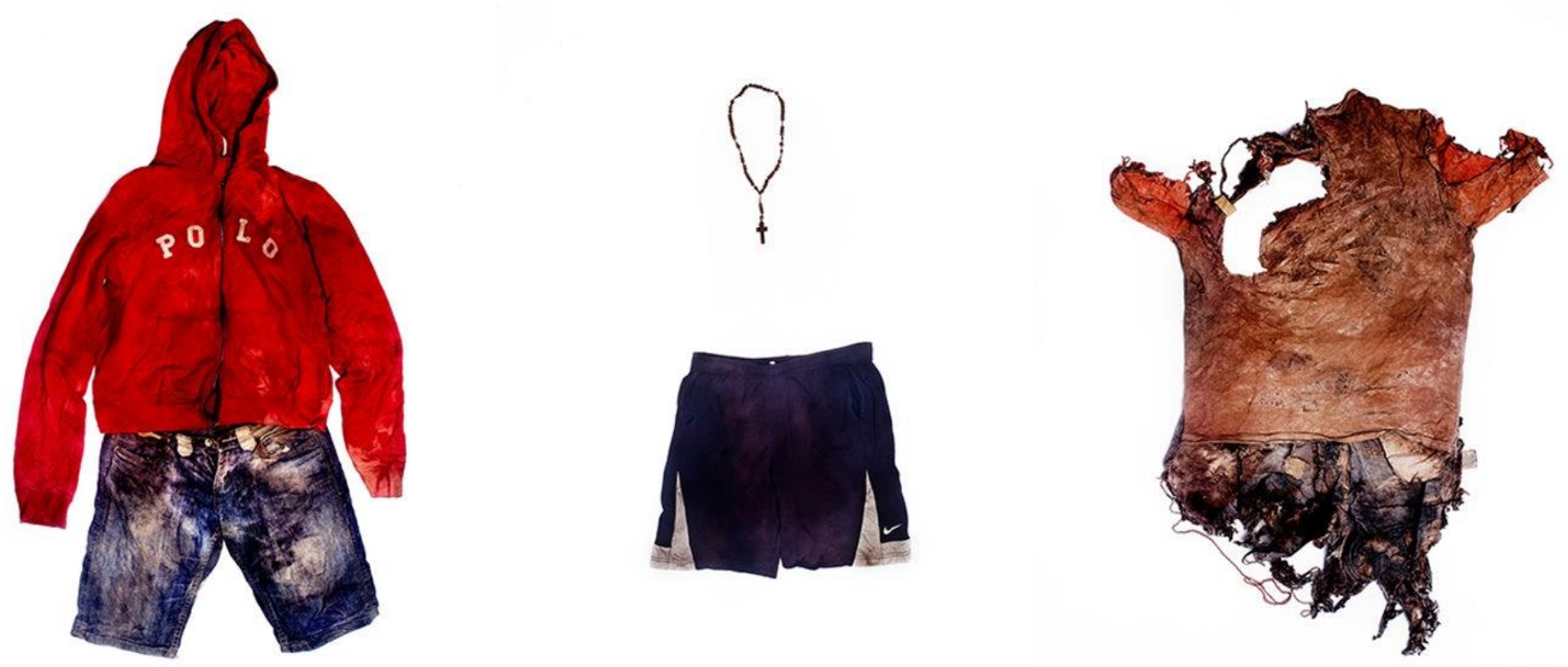

Fonte: Site do fotógrafo Fred Ramos, $(2014)^{7}$.

De acordo com Dada e Ramos (2014):

(...) adolescentes e jovens como os de qualquer cidade latinoamericana; um garoto de bermuda, que usava fones de ouvido. Outra moça de short, com uma camisa branca leve, adequada ao calor dos trópicos. Jeans, jeans, jeans. Uma camiseta com a estampa de um grupo de rock.

O fotógrafo se vale da nossa empatia ao nos contar, por meio desses trajes, a história desses infelizes personagens que integram um sinistro e melancólico registro forense. As descrições destas camisetas, calças jeans, casacos, shorts; podem até lembrar o conteúdo de notas que descrevem peças de figurino em um processo artístico. Uma indagação pertinente seria: podemos, talvez, chamar estes últimos trajes de trajes da cena do crime?

Pela sua permanência concreta estes trajes são fundamentais às implicações jurídicas do processo de reconhecimento dos corpos, ao mesmo tempo em que cumprem um papel doloroso na memória dos familiares. Além

${ }^{7}$ Site do fotógrafo Fred Ramos. Disponível em: https://fred-ramos.com/. Acesso em: 10 jun.2019. 
disso, são retratos codificáveis dos perfis das vítimas e da violência a que foram submetidos e podem identificar dados objetivos como faixa etária, classe social, hábitos de consumo - um intricado conjunto de elementos palpáveis que permitem uma leitura do cenário e dos acontecimentos dos fatos somando-se ao possível reconhecimento de identidades por seus familiares. Outro questionamento possível: podemos considerar este registro documental um documento de história da indumentária? Sim. De fato, essas fotografias trazem elementos de memória e subjetividade dos corpos que habitaram estes trajes. $E$, à sua maneira funesta, são fundamentais para reconstrução da história, tanto em termos sociais como em aspectos antropológicos.

Diferente da série fotográfica em que os trajes não foram escolhidos ou tampouco existiu sepultamento apropriado, segundo Viana (2017) o traje funerário é aquele usado pelo corpo inerte na hora de seu sepultamento. Podemos identificar como documento histórico e traje fúnebre, por exemplo, os trajes usados pela Imperatriz Leopoldina na ocasião de seu enterro - que eram os mesmos trajes usados na consagração de D Pedro (idem).

Trajes que possuem uma história documentada são menos propensos ao esquecimento e aumentam suas probabilidades de sobrevivência, como ideia ou memória. Olhar para os trajes sociais em registros artísticos ou documentais é fazer uma leitura dessas histórias e de um contexto coletivo.

\subsection{Biografia de objetos e uma arte que tem origem no cotidiano}

Existe uma estética do cotidiano que envolve a aura dos objetos, a alma das coisas. A história desses objetos pode ser uma forma de resistir à arquitetura do esquecimento, de fazer com que as velhas casas de portões vazados e suas flores de maio plantadas em potes de margarina não sejam apenas pilhadas e esvaziadas por herdeiros e imobiliárias. O objeto pode, sim, contar histórias, ou ainda, pertencer a uma obra artística, ressignificado.

Podemos elencar inúmeros exemplos em que objetos cotidianos protagonizam projetos na fronteira entre linguagens artísticas e documentação histórica, como no contexto do Museum of Everyday Life (figura 2), sediado em uma pequena cidade americana. Clare Dolan (2019), criadora e curadora do 
museu, comenta a existência do extraordinário no ordinário em entrevista ao The New York Times ${ }^{8}$, enxergando o belo no trivial e sintetiza a ideia do museu no poder de contar uma história que é exercido por objetos comuns, mesmo tão transitórios quanto poeira com uma iluminação específica de certa hora do dia. Esta conjugação de elementos triviais - o pó e a iluminação, podem emanar memórias cotidianas que serão carregadas de subjetividades de acordo com seu interlocutor.

Figura 2 - Museu da Vida Cotidiana, exposição de 2015:

Dust.

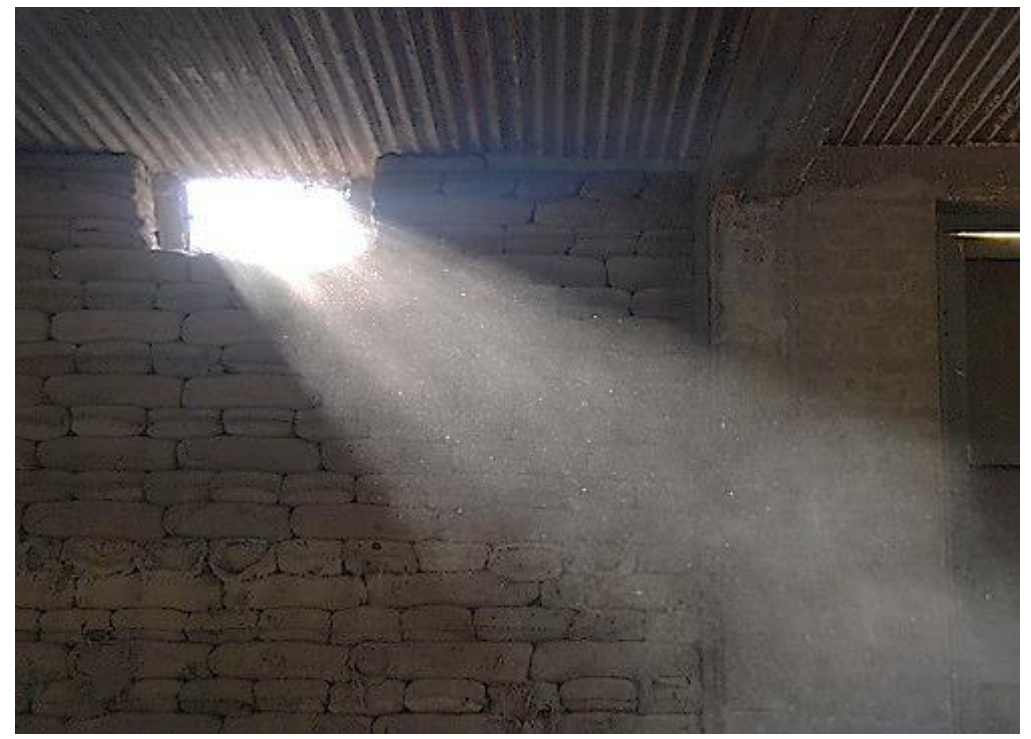

Fonte: Site The Museum of Everyday Life. ${ }^{9}$

Veremos algo semelhante no projeto Willard Suitcases (figura 3), onde são fotografados objetos cotidianos dispostos em malas de internos de um instituto psiquiátrico na ocasião de entrada em suas internações. Objetos que estas pessoas julgaram essenciais para aquele momento de suas vidas, que Ihes eram preciosos, afetivos, imbuídos de significados, mesmo que em um momento após internação não tivessem a mesma aplicação prática que um dia poderiam ter impresso em seus cotidianos - qual a utilidade do objeto relógio, por exemplo, dentro de um contexto em que horários serão controlados por

8 Disponível em: https://internacional.estadao.com.br/noticias/nytiw,museu-de-objetosinsignificantes-transforma-lixo-em-arte,70002810059. Acesso em: 13 out. 2019.

${ }^{9}$ Contato com a obra: internet. Disponível em: https://museumofeverydaylife.org/. Acesso em: 07 jan. 2020. 
profissionais da saúde? De alguma maneira, representavam suas memórias e subjetividades, sendo objetos carregados de impressões de suas vidas até então, como vemos em BOSI:

Mais que um sentimento estético ou de utilidade, os objetos nos dão um assentimento à nossa posição no mundo, à nossa identidade. Mais que da ordem e da beleza falam à nossa alma em sua doce língua natal. [...] só o objeto biográfico permanece com o usuário e é insubstituível. $\mathrm{O}$ que se poderá igualar a companhia das coisas que envelhecem conosco? Elas nos dão a pacífica impressão de continuidade. (1994, p. 360)

Figura 3 - Willard Suitcases: Objetos da paciente Freda B.

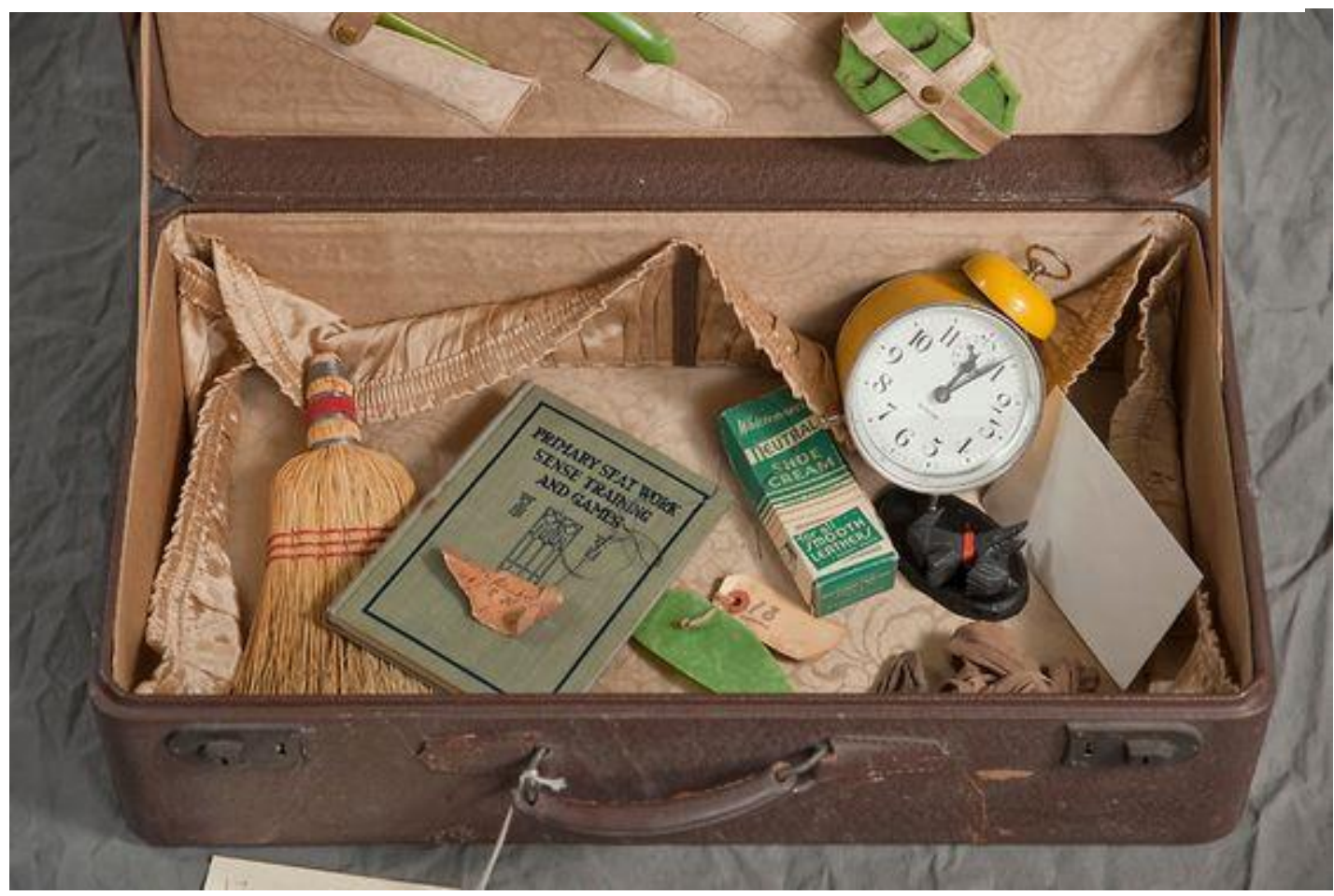

Fonte: Site do projeto Willard Suitcases. Fotografia de Jon Crispin ${ }^{10}$.

Quando falamos de ressignificação e contextos psiquiátricos é impossível não pensar na obra de Bispo do Rosário (figura 4). Segundo Boeira:

Por se encontrar dentro de um espaço de onde não tinha permissão para sair, Bispo encontrava maneiras de aproveitar e ressignificar

${ }_{10}$ Contato com a obra: internet. Site do Projeto Willard Asylum Suitcases, disponível em: https://www.willardsuitcases.com/. Acesso em: 07 jan. 2020. 
elementos de seu cotidiano para confeccionar matéria prima e, depois confeccionar obras de arte a partir delas $(2018$, p. 75$)$.

Bispo promove não apenas uma ressignificação de objetos cotidianos, como também reelabora materiais, por exemplo, ao desfiar uniformes para reutilizar as linhas em seus característicos bordados.

Figura 4 - Bispo do Rosário

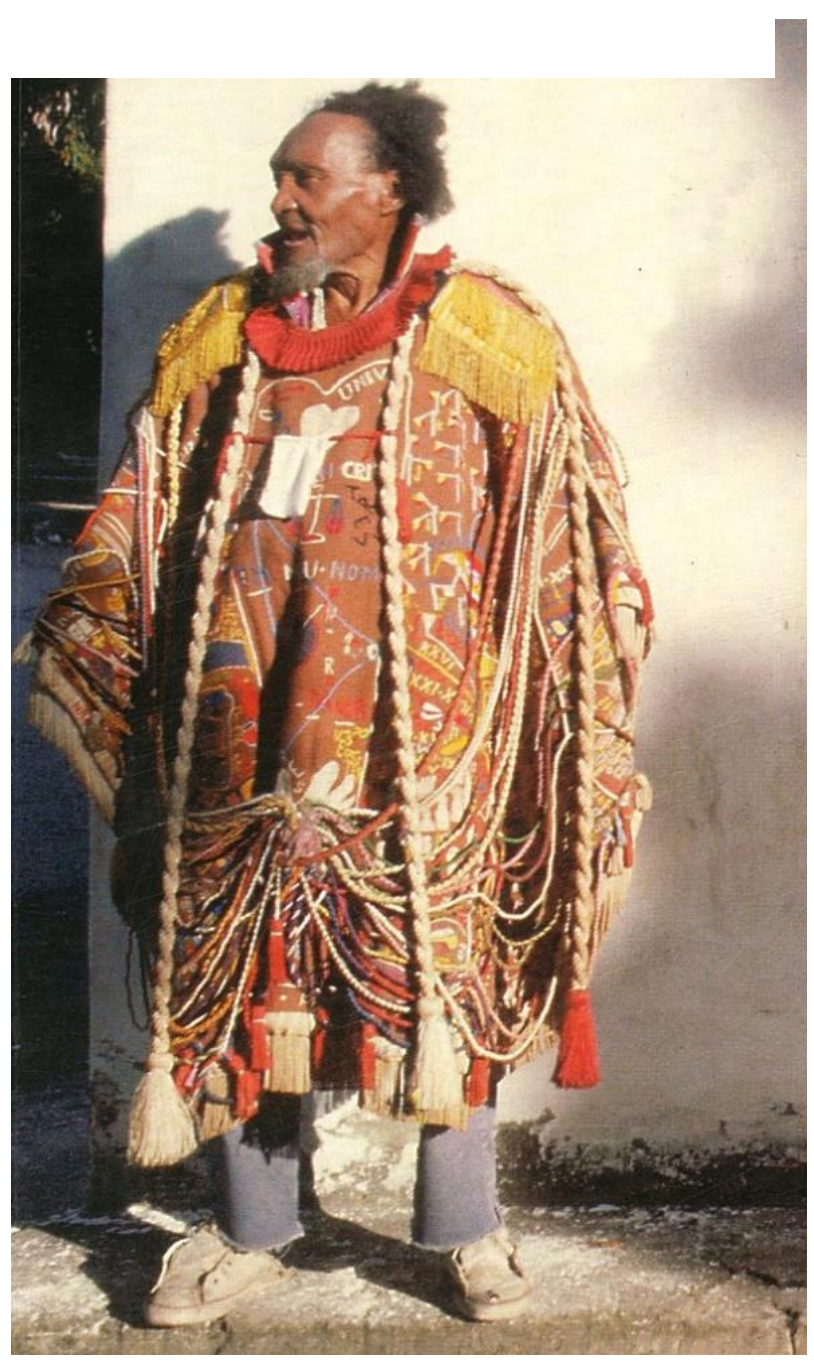

Fonte: Site Obvius Mag ${ }^{11}$.

O objeto deslocado de sua função cotidiana pode servir-se de uma identificação com aquele que entra em contato com a obra quase de maneira imediata, quando acontece uma conexão com histórias e memórias pessoais,

11 Disponível em: http://lounge.obviousmag.org/anna anjos/2012/11/bispo-do-rosario.html Acesso em: 03 mar 2021. 
quando se revisita um apego ou ojeriza a esses materiais. É um objeto conhecido, e nos exemplos citados existe uma aura poética, uma espécie de alma das coisas, que testemunharam memórias de vida. Justamente o elemento banal do acesso a que todos temos a estes objetos pode universalizar e fazer emergir memórias pessoais.

Obviamente isto acontece com o traje, também um objeto cotidiano. Assim como no contexto de linguagem fotográfica, no trabalho citado El Último Atuendo de los Desaparecidos, as fotografias de Ishiuchi Miyako (2015), publicadas no livro From Hiroshima evocam esta relação com memória e subjetividade. Neste trabalho, podemos ver trajes que sobreviveram ao trágico evento da bomba atômica em Hiroshima (figura 5), de conhecimento notório de grande parte do planeta. Miyako fotografa artefatos que estavam em contato com o corpo das pessoas que faleceram durante aquele momento específico, tais como relógios, joias, mas principalmente trajes. Assim como na série fotográfica de El Salvador, essas imagens também causam assombro, empatia, identificação. As fotografias são capazes de manter e segurar nosso olhar, dificilmente nos deixando $\mathrm{ir}^{12}$.

${ }^{12}$ Contato com a obra: livro visto no Centro Cultural Japan House, na cidade de São Paulo - SP. Disponível em: https://www.nytimes.com/2014/10/17/arts/design/ishiuchi-miyako-here-and-nowatomic-bomb-artifacts-hiroshima-1945-2007.html . Acesso em: 20 dez. 2019. 
Figura 5 - Imagem do projeto Clothes that survived Hiroshima.

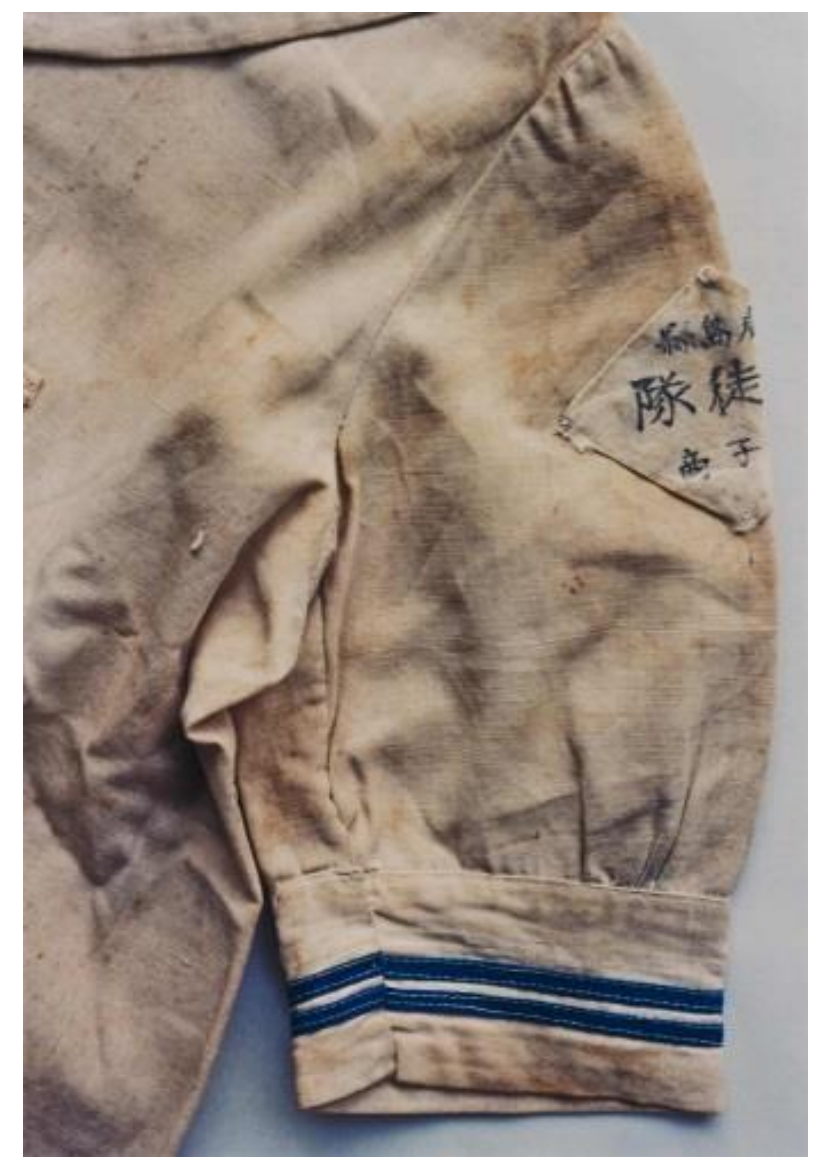

Fonte: Reportagem no site do jornal The Guardian ${ }^{13}$.

É possível enxergar tais projetos para além do aspecto de dor ou mesmo luto carregado por eles, dentro de uma abordagem que pertence a uma ou mais linguagens artísticas. Em tais contextos, artefatos podem mudar de status e integrar obras artísticas: para além de gerar identificação, o artefato também se configura como um registro histórico. A potência desse tipo de obra é um aspecto relevante para sua importância, uma vez que quem frui a obra de arte pode enxergar um reflexo seu ali, representado por um objeto do cotidiano, transportado para uma esfera poética. Quando esta relação acontece com o traje, pode ser muito potente, uma vez que se trata de um objeto com o qual todos nós temos contato em alguma instância. E o traje pode tornar-se arte em diversos contextos, por exemplo, como nos fala Sant'anna em relação à Coleção

${ }^{13}$ Reportagem sobre roupas que sobreviveram Hiroshima, com fotografias de Ishiuchi Miyako. Disponível em: https:/www.theguardian.com/artanddesign/gallery/2015/oct/22/clothes-thatsurvived-hiroshima-in-pictures. Acesso em: 07 jan. 2020. 
Rhodia do Museu de Arte de São Paulo 'Assis Chateaubriand' (MASP), que passa a integrar o acervo do museu em 1972:

Portanto, os objetos-vestuário moda aqui estudados são
socioculturalmente conformados e seus significados são
constantemente rearticulados dependendo de seu contexto (desfile,
editorial de moda, reserva técnica, exposições de arte e/ou de design
etc.), sobrevivendo para além de seus produtores originais e das
pessoas que um dia usaram essas peças hoje musealizadas (SANT'ANNA, 2010, p. 22).

\subsection{0 passado e a memória em oposição a novidade na moda}

Talvez um pouco deslocada da presença da memória dos objetos, a ideia de novidade é um conceito caro para a moda. Svendsen $\left(2010^{14}\right)$ afirma que a moda é transitória, alimentada pela ideia do novo, e Sant'anna nos diz que a moda "é um tipo particular de mudança indissoluvelmente ligada à modernidade e ao exercício (e busca) daquilo que compreendemos como 'novidade'” (2010, p. 40). No entanto, o traje sobrevive para além da moda, muitas vezes ressignificado até mesmo pelos próprios estilistas, ou ainda por figurinistas e pessoas comuns.

Se o valor da novidade é algo tão precioso para a moda, os valores da memória e do passado, presentes na história da indumentária, vão se mostrar valiosos principalmente em contextos afetivos, museológicos ou artísticos. Ao contrário do que veremos em valores e papéis sociais, segundo Gilda de Mello e Souza:

Como se vê, a moda tanto pode refletir as transformações sociais como opor-se a elas através de inúmeros subterfúgios, todas as vezes que há perigo de uma aproximação excessiva entre as classes e os sexos (1987, p. 129).

${ }^{14}$ Svendsen vai dedicar todo um capítulo chamado O princípio da moda - o novo para desenvolver conceitos sobre o valor da novidade na moda, em Moda, uma filosofia (2010). 
No traje de cena, o valor da novidade talvez repercuta em relação a originalidade ou autoria, ou ainda na genialidade e precisão de uma reprodução.

Para Viana, o traje é uma maneira de expressão da cultura e traz "(...) o reflexo de épocas pregressas atuais e até mesmo projeções do futuro(2017, p. 60 )", o que pode ser potencialmente rico para a criação cênica. No traje de cena e na moda, principalmente no século XXI, vemos valores de épocas passadas e futuras se misturarem - o tempo cronológico não necessariamente é expresso de maneira linear.

\subsection{História da indumentária como apoio ao traje de cena}

O traje permite "constituir um panorama das formas de vestir de uma época e de um espaço culturalmente e socialmente específicos" (ANDRADE, 2008, p. 23) o que se mostra especialmente útil em processos de criação de figurinos realistas, que necessitam transparecer e até mesmo reproduzir certos contextos ou épocas.

Quando um figurinista necessita do acesso ao registro histórico de algum traje, seja no audiovisual ou nas artes cênicas, isso pode ser feito via acervo material ou de imagens. O próprio James Laver ${ }^{15}$ atuou como consultor de trajes de época em cinema e teatro (VIANA, 2017, p. 70), devido a sua bagagem como historiador da indumentária e atuação no Museu Victoria and Albert, na Inglaterra. Geralmente, a reprodução de um traje histórico vai servir a uma cena realista, embora nem sempre siga fidelidade histórica rígida.

Aqui é importante diferenciar o ato de recriar e o de reconstituir: enquanto recriar significa criar novamente, fazer de novo, reconstituir traz o significado de tornar a constituir; recompor ${ }^{16}$. Barthes sinalizava em As doenças do traje de cena $^{17}$ sobre os perigos de uma hipertrofia da função histórica e o perigo das reconstituições, um exagero dos detalhes, fazendo com que o público reconheça

\footnotetext{
15 James Laver, historiador britânico, natural de Liverpool, atuou no Museu Victoria and Albert durante 37 anos, além de ser autor de diversas publicações sobre história da moda, tais como $\mathrm{A}$ roupa e a Moda. (VIANA, 2017)

${ }^{16}$ Conforme consultado no dicionário Michaelis online. Disponível em: http://michaelis.uol.com.br/moderno-portugues/. Acesso em: 20 Dez. 2019

17 Tradução de Fausto Viana, presente em Roland Barthes e o Traje de Cena (VELLOSO; VIANA, 2018).
} 
esforço de fazer o traje parecer verdadeiro, mas ao mesmo tempo pouco crível (BARTHES, Apud VELLOSO; VIANA, 2018, p.54). A figura 6, da série audiovisual Chernoby ${ }^{18}$, retrata uma escolha da equipe de figurino para que 0 traje seja crível, mesmo que talvez não historicamente acurado.

Figura 6 - Cena da série Chernobyl da HBO

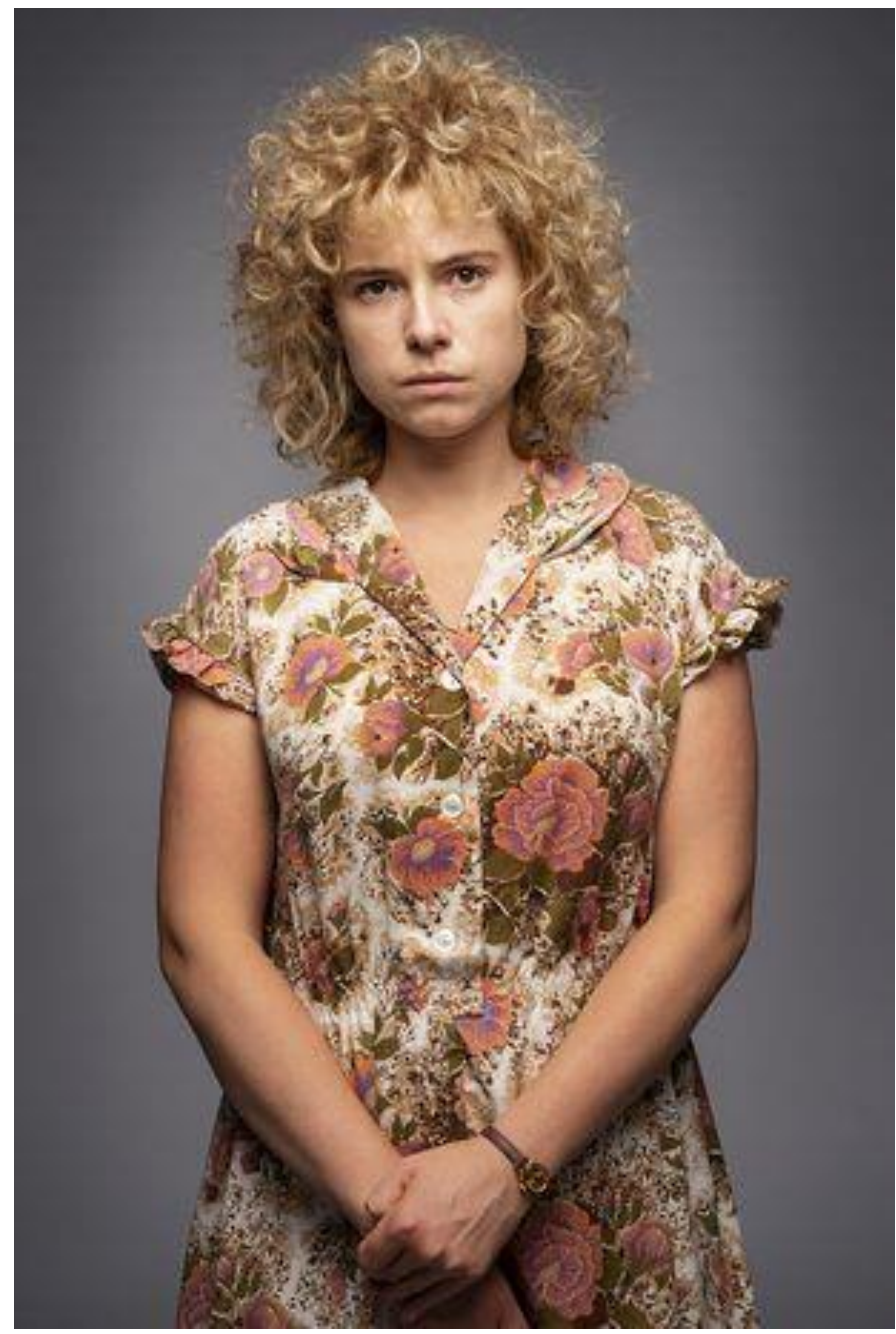

Fonte: Site Espetaccolo ${ }^{19}$

Esta escolha retrata não uma reconstituição fiel, mas sim uma recriação que tem base em um imaginário ocidental sobre os trajes daquela época e local, uma escolha pelo uso de um imaginário talvez mais crível para o público, uma

${ }^{18}$ Chernobyl, série do canal HBO de 2019, retrata os trágicos acontecimentos da Usina na cidade de Pripryat, no ano de 1986.

${ }^{19}$ Site Espetaccolo. Disponível em: https://tg24.sky.it/spettacolo/serie-tv/2019/05/25/chernobylserie-tv-cast-personaggi-foto. Acesso em: 25 nov. de 2020. 
vez que havia poucos documentos confiáveis da época para esta consulta e possível reprodução. É provável que os trajes daquele contexto fossem mais coloridos e metropolitanos que os retratados na série, mas a equipe de figurino escolheu seguir um imaginário ocidental sobre a União Soviética na década de 1980, como vemos na reportagem de Vasquez 20 , de 2019.

\subsection{0 traje de cena a partir do traje social - a que cena serve?}

Um figurino de uma linguagem artística, seja cinema ou teatro, vai envolver questões para além da necessidade, proteção e pudor. Neste caso, não se trata de apenas vestir um corpo, e sim uma ideia. Estas questões passam pelo imaginário e memórias relacionados à indumentária, para que então o traje de cena seja desenvolvido e confeccionado. Este traje faz parte do processo do tornar-se outro relacionado à arte do ator, sendo suporte para criação e interpretação, segundo Hoffman:

\footnotetext{
O traje de cena pode também estar relacionado às práticas discursivas contemporâneas, que através de um conjunto de roupas e acessórios contam histórias, criam personagens e compartilham situações. Logo, pode-se pensar que essa composição abrange muito mais que 0 "vestível" e inclui atitudes e comportamentos que potencializarão os modos de ser de cada um (apud Viana; Muniz, 2010, p. 169).
}

A memória do traje civil ordinário, do corpo trivial, comum, é fundamental nos processos de pesquisa e criação de trajes de cena. São muito ricas as relações traçadas entre vida, arte e indumentária, exploradas em diversas linguagens artísticas. Objeto com uma biografia, o traje social tem certas características que vão incluir elementos de sua materialidade, de sua manufatura, seu papel social, por quais subjetividades passou.

Se podemos dizer que o trabalho do figurinista se constrói de maneira efêmera, tanto no cinema quanto no teatro, também podermos traçar diversas relações acerca de memória e registro do traje social e do traje de cena, bem

\footnotetext{
${ }^{20}$ Reportagem do site El País: "Nunca soubemos nada de Chernobyl, nem como as pessoas se vestiam". Disponível em: https://brasil.elpais.com/brasil/2019/06/03/cultura/1559579086 146645.html. Acesso em: 25 nov. de 2020.
} 
como sobre a sobrevivência de cada um destes trajes, com suas origens e significados. No entanto, em relação a registro e documentação, o traje de cena tem mais chance ou garantia de permanecer, para além de memórias pessoais ou afetivas, por conta do registro das produções em que está envolvido.

Poderíamos talvez considerar o traje de cena também roupa de dia santo? Quem vai afirmar algo semelhante neste sentido é o ator do grupo Galpão, Antônio Edson, que faz uma relação entre o traje de cena com roupa de gala ou roupa de ir à missa, declarando que o traje ampara e sustenta a criação do personagem dentro de um processo criativo (PEREIRA, 2012). Tanto a memória quanto a materialidade do traje podem funcionar como suporte ou material disparador dentro de uma criação, como no espetáculo $E$ a noiva não quer casar (1982) onde a dramaturgia se desenvolve a partir de um traje, um vestido de noiva, encontrado em um baú de trajes trazido pelo ator Eduardo Moreira durante o processo de criação (Ibidem, p. 41).

Nas artes cênicas, o traje requer uma duração que deve resistir por temporadas de apresentações. Sua configuração material será colocada à prova em repetições, é-Ihe exigido resistência: ele precisa durar, rolar no chão se o trabalho do ator assim pedir, ser substituído por outro igual caso necessário, com cópias disponíveis instantaneamente se o orçamento assim o permitir. Já no cinema e no audiovisual, o registro está garantido devido à natureza da linguagem artística, embora sua sobrevivência como objeto material não seja constante. Na minissérie global Hoje é Dia de Maria, por exemplo, um dos trajes de cena era feito de papel, e por isso existiam três cópias deste, devido à sua fragilidade (informação verbal ${ }^{21}$ ). O traje foi assinado pelo estilista Jum Nakao ${ }^{22}$.

Quando o traje social é incorporado a um traje de cena, é necessário que ele sobreviva. Podemos citar, no contexto contemporâneo do traje de cena nas artes cênicas, diversas ocorrências onde o traje social ocupa um lugar para além da questão orçamentária ou de fidelidade histórica. O uso da roupa de segunda mão por motivos orçamentários não necessariamente vai implicar relação com a

${ }^{21}$ Conforme discorrido em conversa informal com Tiche Vianna, diretora teatral e preparadora corporal do elenco da série global.

${ }^{22}$ Como podemos ver no site do estilista. Disponível em: https://www.jumnakao.com/portfolios/hoje-e-dia-de-maria/. Acesso em 30 jan. 2021. 
memória ou a subjetividade, o que pode vir a acontecer, mesmo sem ter sido a intenção inicial.

Interessam-nos aqui contextos em que a imaginação e a performatividade atravessam o traje social, para além do objeto roupa de segunda mão. Antes de nos debruçarmos nos estudos de caso, elencamos neste capítulo dois exemplos de contextos em que o traje social faz parte de escolhas narrativas durante os processos de criação. Vemos essa escolha bem pronunciada quando o traje de cena se relaciona com as subjetividades presentes na dramaturgia, seja quando esta é contemporânea, caso do espetáculo Les Éphémères, do Theatre du Soleil; ou ainda quando se situa em outro momento histórico, como em Hygiene e Hysteria, do Grupo XIX de Teatro. Trataremos, então, de cada exemplo a seguir.

\subsection{Imaginário e bazar de objetos em Les Éphémères}

Imaginação é um termo caro para Ariane Mnouchkine, fundadora e diretora do Theatre du Soleil. Podemos considerar o contexto da criação do figurino do espetáculo Les Éphémères (2006) como uma oportunidade de atravessamentos entre traje social e traje de cena. Marie Helene Bouvet, uma das figurinistas, conta em entrevista à revista Sala Preta (BOUVET, 2007) ${ }^{23}$ que tanto o processo de criação dos trajes de cena quanto a dos objetos envolveram uma intensa busca por objetos e roupas de segunda mão, que empenhou atores e equipe de figurino. Para além deste verdadeiro bazar, como Bouvet vai nomear, ela nos conta que trouxe roupas da própria mãe, que havia sido internada em um asilo recentemente. Essas roupas foram incorporadas pelos atores durante o processo criativo do espetáculo, composto por 29 pequenas histórias construídas a partir de lembranças ou vivências pessoais do próprio grupo. Também estão presentes peças de vestuário que haviam pertencido a outras pessoas do grupo “(...) assim, há muita roupa da minha mãe no espetáculo: na Gaelle, em personagens da Juliana... E não só nas roupas que eu trouxe. A Liliana, o Jean-Jacques...tem roupa de todo mundo no espetáculo". (Ibidem, p.118).

23 Tanto pauta quanto entrevista foram realizadas pelos pesquisadores Fausto Viana e Rosane Muniz, embora na citação conste o nome de Marie Helene Bouvet, a entrevistada. 
Para Mnouchkine, a imaginação parece ser mais cara que a memória ou a reprodução fiel de um traje, que pode ser entendida como uma redundância. Ela diz “(...) por que exprimir a lentidão com lentidão? O teatro não gosta de tais redundâncias" (FÉRAL, 2010, p.44). Mnouchkine também rejeita a ideia de uma suposta originalidade "(...) aceitem às vezes ser uma cópia modesta. Duvidem da originalidade a qualquer preço". (Ibidem, p. 46).

\subsection{Os trajes do Grupo XIX}

Outro momento em que o traje social se faz presente como materialidade e imaginação são os dois primeiros trabalhos do Grupo XIX, os espetáculos Hysteria e Hygiene. Este grupo nasce na Escola de Arte Dramática (EAD) da Universidade de São Paulo (USP) no começo do século XXI, e terá como grande característica o processo colaborativo. Estes dois primeiros espetáculos narram dramas sociais e políticos ${ }^{24}$.

Ambos têm como característica uma forte presença da materialidade do registro histórico, que influencia diretamente a dramaturgia, seja pelos elementos arquitetônicos ou objetos de cena. Os personagens destas duas dramaturgias não são exatamente visíveis no estudo da história da indumentária, são tipos marginais, tais como as internas de um hospital psiquiátrico em Hysteria (2001), ou os habitantes de cortiços de Hygiene (2005). De acordo com Renato Bolleli Rebouças ${ }^{25}$, os materiais presentes na direção de arte foram definidores nestas duas montagens, como em Hysteria:

Enquanto Marques garimpa figurinos de época do acervo do CAC/EAD, as atrizes miram-se nos exemplos das avós, tias e mães. É dessa mistura que, num dos ensaios, é lançada ao centro da sala uma muda de roupas. Cada uma escolhe, experimenta a peça que mais

\footnotetext{
24 Para esta seção de nosso primeiro capítulo, usamos como fontes a experiência pessoal do contato com a obra por parte da autora; o livro publicado pelo grupo em 2006, como parte do projeto Casa em Obras, contemplado pelo Prêmio Funarte de Teatro Myriam Muniz, além da seção sobre 0 grupo na Enciclopédia Itaú Cultural. Disponível em: https://enciclopedia.itaucultural.org.br/grupo458682/grupo-xix-de-teatro. Acesso em: $01 \mathrm{de}$ fev. de 2021.

${ }^{25}$ Rebouças foi diretor de arte do grupo nas duas montagens, e sua dissertação de mestrado é uma de nossas referências bibliográficas.
} 
gosta, de modo que o tempo faça o melhor ajuste em sua personagem. (...) Coletivamente, como demanda o processo, decidem por tecidos de renda, tons pastéis, saias brancas rodadas, lenços etc. (2010, p. 28)

Já em Hygiene, que ocupa o espaço da Vila Operária Maria Zélia, esta presença da materialidade parece ainda mais impactante. Como material têxtil que integrou os trajes de cena e a direção de arte do espetáculo, fizeram parte "as rendas de Dona Margarida, os guardanapos portugueses de Dona Gilda, (...) sapatinhos de amarrar e banquinho de Dona Ernestina". (Ibidem, p. 107), moradores idosos da Vila Maria Zélia, que emprestam suas memórias e vivências pessoas aos trajes e objetos presentes no espetáculo. Como nos diz Viana na publicação do grupo, "os pincéis do tempo fizeram o trabalho, levando o público ao exercício pleno da imaginação" (2006, p.88). O resultado desse traje de cena imprime certa fidelidade ao período histórico, sem pretensão de ser uma reprodução, com a presença de artefatos de memória afetiva dos moradores da Vila Maria Zélia. Podemos ver na figura 7 um pouco do jogo entre memória e imaginação que habitou objetos e trajes desse trabalho:

Figura 7 - Detalhe do trabalho Hygiene

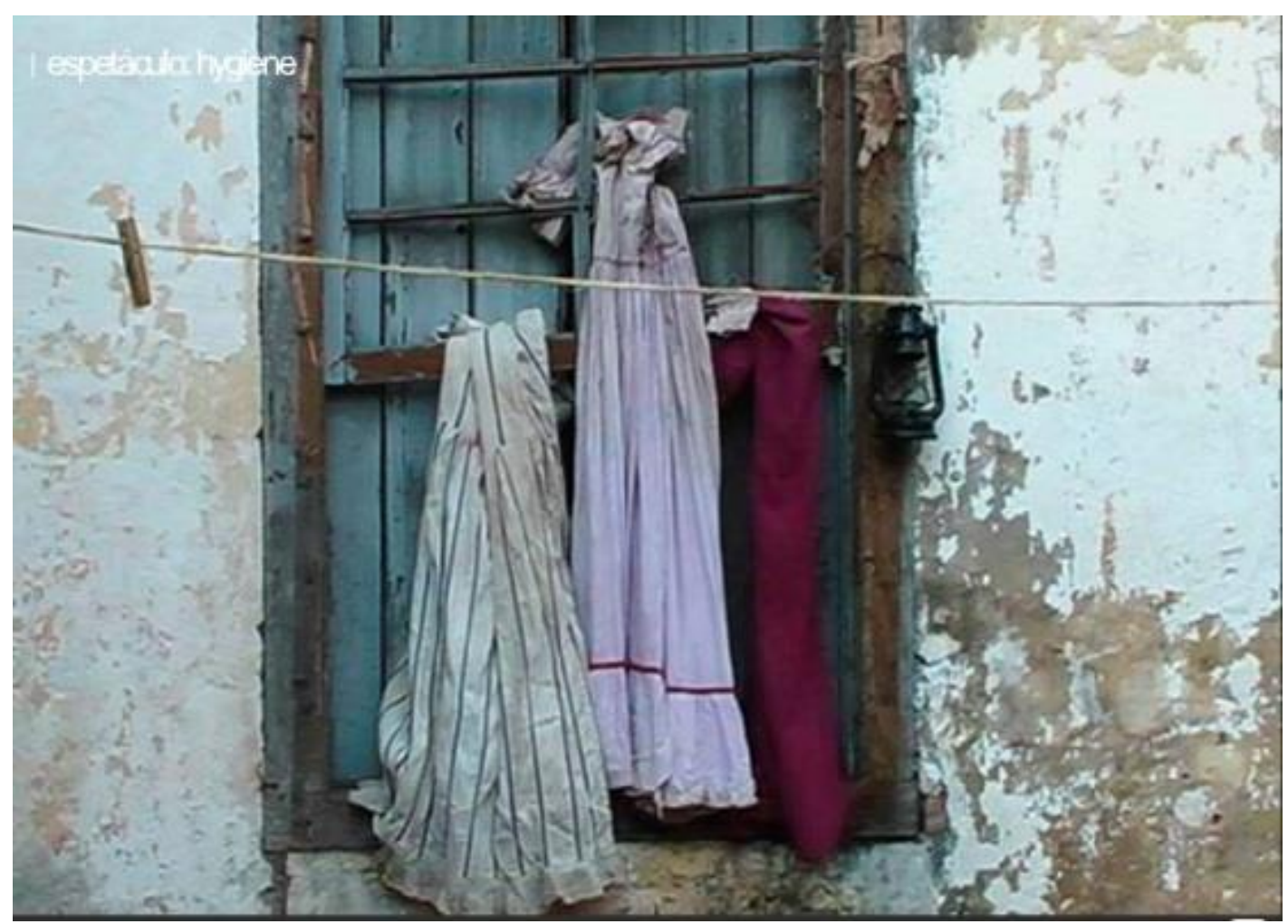


Fonte: Site do Grupo XIX de Teatro ${ }^{26}$.

Quando o traje de cena se serve do traje social, essa relação com a subjetividade pode ficar ainda mais clara, expondo questões para além da moda e materialidade. Sequeira e Andrade consideram a roupa como um território de criação, suporte de ações poéticas e políticas, possibilidade de narrativas vestíveis, escancarando a relação entre traje e subjetividade, buscando um significado a decifrar nos corpos vestidos não como são, mas como estão sendo:

(...) um modo de pensar que acata o fluxo da vida, os modos de agir que revelam até o mais perturbador, porque não estão dados a priori e porque atacam a temporalidade linear da moda. Os gestos desencadeados pelas roupas encontram seu sentido na medida em que performam no espaço. Podem aderir às determinações mais cristalizadas de um campo social, mas também podem quebrar seus roteiros mais consolidados, instaurando outras realidades possíveis. SEQUEIRA E ANDRADE (2017, p. 12)

Ao pensar a roupa como uma narrativa vestível, um território habitado pela imaginação, podemos concluir que o traje social expressa subjetividades, o que torna infinito seu potencial no traje de cena e na performance.

${ }^{26}$ Site do Grupo XIX de Teatro. Disponível em: http://www.grupoxix.com.br/. Acesso em: 6 jan. 2020. 
Capítulo 2 - Descaracterizar-se: infiltração das subjetividades

Estava preparada para realizar grandes feitos, mas não para usar coturnos tamanho 42, ao invés de 35.

(Svetlana Aleksévitch, A Guerra não tem rosto de mulher) 
Nossas roupas podem traduzir nossa identidade e estados de ânimo; bem como se relacionar (ou não) com cenários e o outro a quem vamos encontrar. A roupa marca nosso tempo, tanto o tempo histórico, quando falamos em história da indumentária, quanto o tempo cotidiano, aquele que diz respeito a estarmos em determinados locais, como no trabalho ou em espaços íntimos e pessoais, como por exemplo nossas casas. Nossos trajes são contornos, mesmo quando escolhemos não deixar tais contornos aparentes, por escolha própria, ou por uma displicente rebeldia, que também é uma escolha pronunciada, embora se esforce em não parecer. Nos apropriamos da realidade da roupa, do cheiro e das texturas, que vão nos trazer sensações e camadas de imaginário que são relevantes tanto em nossos cotidianos, quanto em processos artísticos.

Tais contornos, sensações e camadas de imaginário são parte do nosso vestuário cotidiano, e foram durante um ano parte de uma experiencia artística, ao integrarem um programa de performance, da artista Beatriz Cruz, que performou e se registrou ao vestir a indumentária de outras pessoas. Artista criadora paulistana, performer, Cruz tem como interesses centrais para suas experiências artísticas o corpo, a cidade e o gênero ${ }^{27}$. Desde 2015 realiza de forma independente o Projeto Desandar, onde cria e experimenta uma série de programas de performance para investigar o processo de produção e transformação de subjetividades.

Dentro deste projeto, se situa a performance duracional Descaracterizarse, alvo de nosso interesse. Registrada na rede social Instagram, a performance se serve, nas palavras de Cruz, do seguinte programa:

Convido pessoas e peço que me vistam com suas próprias roupas por uma semana. Arrisco uma nova caracterização. Cubro-me, envolvome, envergo-me por um outro contorno cotidiano. Delineio figuras no meu corpo, modos de ser ou estar. (PROJETO DESANDAR, 2018)

O programa de uma performance é um conjunto de ações previamente estipuladas, a ser realizado pelo artista, pelo público ou por ambos sem ensaio

27 Como disposto na seção "sobre" do site do Projeto Desandar. Disponível em: https://projetodesandar.weebly.com/sobre.html. Acesso em: 09 nov. 2020. 
prévio, como definiu Eleonora Fabião (2013). Nesse caso, a ação da performance desenhada por Cruz se tratava de trocar trajes durante determinado tempo com seus participantes, o que também vai incluir a troca de subjetividades, performatividades e memórias.

A autora contatou esta performance em um primeiro momento pela rede social Instagram, onde Cruz oficialmente registrava imagens, sensações e afetos sobre cada troca. Quando surgiu a oportunidade, esta autora visitou presencialmente a Mostra Descaracterizar-se (figura 8), na Oficina Cultural Alfredo Volpi, em São Paulo, onde pôde participar do programa e conversar com a performer.

Figura 8 - Cartaz da Exposição Descaracterizar-se

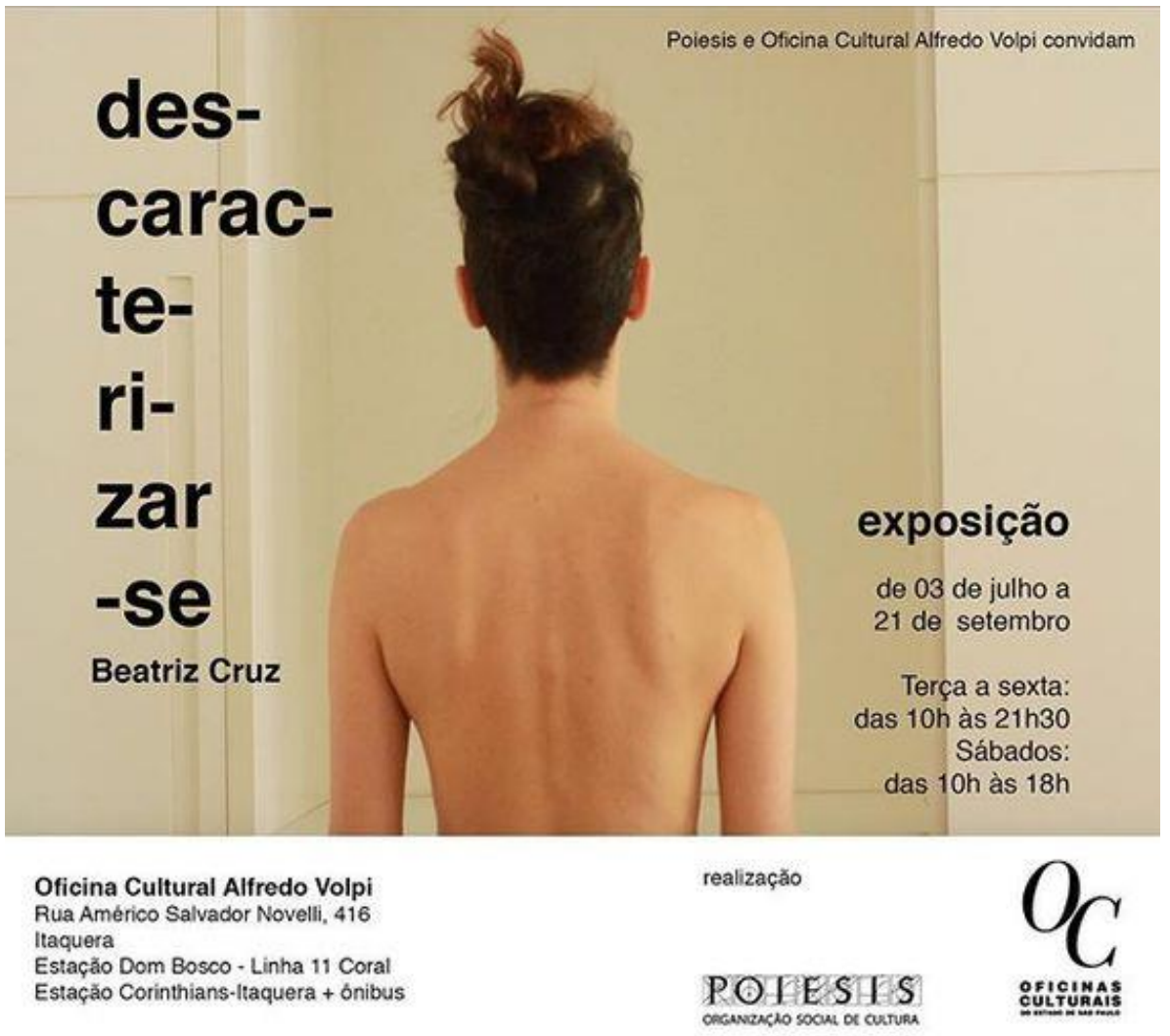

Fonte: Instagram do Projeto Desandar28, 2017.

28 Disponível em: https://www.instagram.com/p/BlsZli3Bmn3/?utm source=ig web copy link. Acesso em: 12 out. 2020. 
Além de um registro imagético, a performer fazia um registro escrito, disponível na rede social, das sensações trazidas pelos trajes, com muitas referências a elementos de presença e da ação durante a performance Descaracterizar-se.

Quando nos referimos a performance arte, estamos falando de uma linguagem recente, um termo com origem por volta do final da década de 1960, embora talvez sempre tenha existido com outros nomes, também em outros contextos não necessariamente artísticos, ligados a comportamentos cotidianos. Richard Schechner (2003) nos diz que podemos entender performance em diversos aspectos, em esferas rituais, artísticas, cotidianas. Já Josette Féral (2009) vai falar de dois eixos, da performance como arte e da performance como experiência e competência.

Talvez a definição de Fabião (2016) nos ajude a entender esse contexto: "é uma cena, mas é claro que não é uma cena"29. Para Fabião, definir performance é de fato um falso problema, algo muito difícil de enquadrar, onde toda potência e força estão em justamente escorregar de definições. Uma característica muito potente que podemos observar é a do estreitamento de distâncias entre arte e cotidiano, elemento central em Descaracterizar-se, onde a performer executa ações que pertencem ao enunciado em seu dia a dia.

\subsection{Trajetória e influências da performer}

A trajetória da artista criadora paulistana Beatriz Cruz elege como interesses centrais o corpo, a cidade e o gênero (PROJETO DESANDAR, 2018). Ela vai dedicar-se a projetos e propostas que mesclam linguagens e propõem atravessamentos entre arte e vida. Seu site nos informa que ela participa do Coletivo Teatro Dodecafônico desde 2008, onde "(...) pesquisa o caminhar como prática estética e política e as questões de gênero no espaço público". Durante entrevista (Beatriz Cruz, entrevista, apêndice A), ela nos conta que começa a se enxergar como performer durante ações desenvolvidas em uma estação

${ }^{29}$ A performer carioca durante o programa "Arte do Artista", da TV Brasil. Ela termina o programa com a ação "Troco Tudo", onde se veste com o traje do apresentador, Aderbal Freire-Filho. Disponível em: https://www.youtube.com/watch?v=TjbXCc8j5r0. Acesso em: 10 jun. 2019. 
colaborativa de performances, chamada La Plataformance ${ }^{30}$, um coletivo de artistas que desenvolveu mapeamento de ações e festivais, criado para fomentar circulação e formação de ações performáticas.

Cruz vai elencar trabalhos de performers que foram relevantes em sua trajetória, como a cubana Ana Mendieta (1948-1985), artista que viveu nos Estados Unidos e traz uma abordagem interseccional de identidade, raça, gênero, classe e faixa etária em seus trabalhos ${ }^{31}$; Yoko Ono (1933), que desde a década de 1960 tem trabalhos artísticos relevantes ${ }^{32}$, entre eles a performance chamada Cut Pieces (1964), onde o elemento têxtil é protagonista ${ }^{33}$; ou ainda Regina José Galindo ${ }^{34}$, artista visual guatemalteca que tem como grande interesse a questão da violência de gênero. Em comum, essas referências performáticas têm foco em experiências identitárias e como elas se desenvolvem, o que será muito visível no trabalho de Cruz.

\subsection{Caminhar para desandar e (então) descaracterizar-se}

O projeto Desandar acontece desde 2015 e aponta diversos elementos que criam o cenário para a performance que é foco desse capítulo, Descaracterizar-se. A trajetória narrativa desse projeto é composta “(...) por uma série de programas de performance para o sujeito, a cidade e o fim do mundo" (PROJETO DESANDAR, 2018). Desandar nasce da ação de caminhar, e vai propor diversas espécies de trocas afetivas, estados de presença e ações, como a própria performer vai descrever (Beatriz Cruz, entrevista, apêndice $A$ ):

Como eu andava muito na cidade, eu andava muito para dentro, nessas muitas camadas onde construímos a nossa subjetividade.

30 Seção "sobre", com informações sobre a estação colaborativa La Plataformance. Disponível em: https://laplataformance.blogspot.com/p/sobre.html. Acesso em: 10 jan. 2021.

${ }_{31}$ Tradução nossa. Disponível em https://www.moma.org/artists/3924. Acesso em 08 de dez. de 2020.

${ }^{32}$ Tradução nossa. Disponível em: https://www.moma.org/artists/4410. Acesso em 08 de dez. de 2020.

${ }^{33}$ Nesta performance, Ono se coloca disponível para que o público corte pedaços de suas vestes, de certa maneira, o público interfere em suas vestes, por isso achamos relevante destacar esse trabalho. Disponível em: https://vimeo.com/106706806. Acesso em: 12 jan. 2021.

${ }^{34}$ Tradução nossa. Disponível em: http://www.reginajosegalindo.com/en/home-en/. Acesso em: 08 dez.2020. 
Constrói, desconstrói, reconstrói. Então acho que essa foi uma grande referência, sabe? Esse pesquisar do caminhar, na performance.

Se o caminhar é uma ação cotidiana, nos parece coerente que a performer investigue 0 ato de vestir-se, outra ação tão cotidiana quanto. Em experiências cênicas anteriores, Cruz relata que não se considerava uma atriz exatamente engajada quanto ao traje de cena (Beatriz Cruz, entrevista, apêndice A):

Nunca foi um suporte que eu criasse muito em cima, nas peças sempre tinha algum figurinista, criação coletiva, existia diálogo, e como performer eu acho que nunca foi o centro da minha atenção, no processo criativo era a última coisa que eu ia pensar.

Embora relate este histórico com relação ao traje de cena, sua performance vai trazer à tona pontos relevantes onde subjetividades e vestuário se encontram. Para além de um traje da performance, Cruz propõe uma investigação entre o traje social e subjetividades cotidianas. A artista relata que a performance começa a acontecer quando se abre o programa nas redes sociais e a partir dessas redes começa a haver troca, diálogo. "Quando tem isso do outro também estar vendo, estar interagindo, me ajudava a pensar sobre" (Beatriz Cruz, entrevista, apêndice A). Schechner (2003, p. 26) diz que "mostrarse fazendo é performar; apontar, sublinhar e demonstrar a ação", o que vemos acontecer nessa interação via rede social.

Esse contato online também ajudou a artista a manter certa frequência de registro, em imagens e em textos. Postar todo dia virou compromisso, ação parte da performance duracional, uma vez que havia retorno e reação, importante para a experiência como um todo.

Durante a performance que estamos investigando, observamos que 0 traje social fez parte de seu enunciado, uma vez que a performer vestiu-se e registrou as sensações que as subjetividades presentes em cada indumentária, sobrepostas as suas. "Acho que essa questão da roupa, tem muito a ver com como os outros te vêem" (Beatriz Cruz, entrevista, apêndice A). Vestir-se é uma 
ação cotidiana, logo, será objeto de diversos enunciados e programas performáticos.

Uma das influências de Descaracterizar-se, que vai aparecer constantemente nos registros, é o trabalho do artista Flávio de Carvalho ${ }^{35}$, artista brasileiro célebre por suas performances, em especial as Experiências, das quais pertencem o célebre New Look (Experiência n. 3, 1956), onde o artista trajava um design idealizado por ele, duas peças, um blusão e uma saia plissada, meia calça arrastão, um design idealizado para o homem tropical. Segundo Carvalho (2004, P. 188), a roupa:

(...) anuncia nosso estado de espírito e traduz nossa identidade, rupturas individuais ou coletivas, presentes em elementos históricos de design, como o rufo: a gorjeia que apresentava a cabeça separada do corpo (fins do século XVIII), atuando magicamente na história, efetivamente provocou mais tarde o corte em massa de cabeças.

Cruz (2017) vai citar Carvalho em alguns momentos do registro da performance, e um deles ilustra um aspecto que é um dos pontos nevrálgicos (FÉRAL, 2009) da performance, a relação entre traje e gênero:

(...) lembro de uma das conclusões de Flavio de Carvalho em A Moda e o Novo Homem: "a moda masculina e feminina tem pontos de encontro que chamo de Idades Púberes, dinamizadas por um processo de nivelamento entre o homem e a mulher e que recebe na história a denominação de 'feminismo'. Nas Idades Púberes, homens e mulheres se vestem da mesma maneira". (Instagram do Projeto Desandar, CRUZ, 2017)

35 Flávio de Rezende Carvalho (1899-1973) foi arquiteto, artista plástico, escritor e animador cultural com presença na vida paulistana desde fins dos anos 1920. Além das obras realizadas sobre suporte convencional, introduziu outras cuja existência depende do apoio da mídia impressa, intervenções que se iniciam com os primeiros projetos arquitetônicos discutidos no espaço do jornal e se estendem à Experiência ${ }^{\circ} 2$, realizada como provocação a uma procissão de Corpus Christi, ao lançamento do traje de verão e à expedição de primeiro contato com tribos indígenas do Alto Rio Negro. Disponível em: https://mam.org.br/exposicao/flavio-de-carvalho/. Acesso em: 25 jan. 2021. 


\subsection{O gênero como ponto de partida}

É relevante pensar que a investigação da performer comece pelo gênero, como ela vai relatar em entrevista, que o programa da performance nasce de um questionamento da artista durante um trabalho de criação da linguagem dança, quando ela propõe a leitura de alguns textos sobre este tema, bem como a troca de peças de roupa com pessoas de diferentes gêneros (Beatriz Cruz, entrevista, apêndice A). Essa característica será pulsante na performance Descaracterizarse, quando Cruz vai vestir trajes de pessoas de gêneros diversos ao seu.

O que no contexto das artes da cena vamos chamar de performatividade se relaciona com presença, ação, descrição (FÉRAL, 2009). Uma das ideias que Judith Butler (2010) nos apresenta é a de performatividade de gênero, talvez mais social, antropológica e política, ligada a manifestações identitárias, sobre como o sujeito vai se identificar para então performar socialmente. Descaracterizar-se parece equilibrar-se entre ambos, e em diversos momentos usa, descreve e sublinha a performatividade de gênero como ingrediente para o acontecimento da arte da performance. "Haverá um 'gênero' que as pessoas possuem, ou é o gênero um atributo essencial do que se diz que a pessoa é", nos pergunta Butler (2010, p. 28). O traje desempenha um importante papel nessa interpretação cultural, como quando acompanhamos a reação das pessoas ao traje que Cruz usa na troca com o participante Rodrigo (figura 9). 
Figura 9 - Vestindo a jaqueta masculina do participante Rodrigo

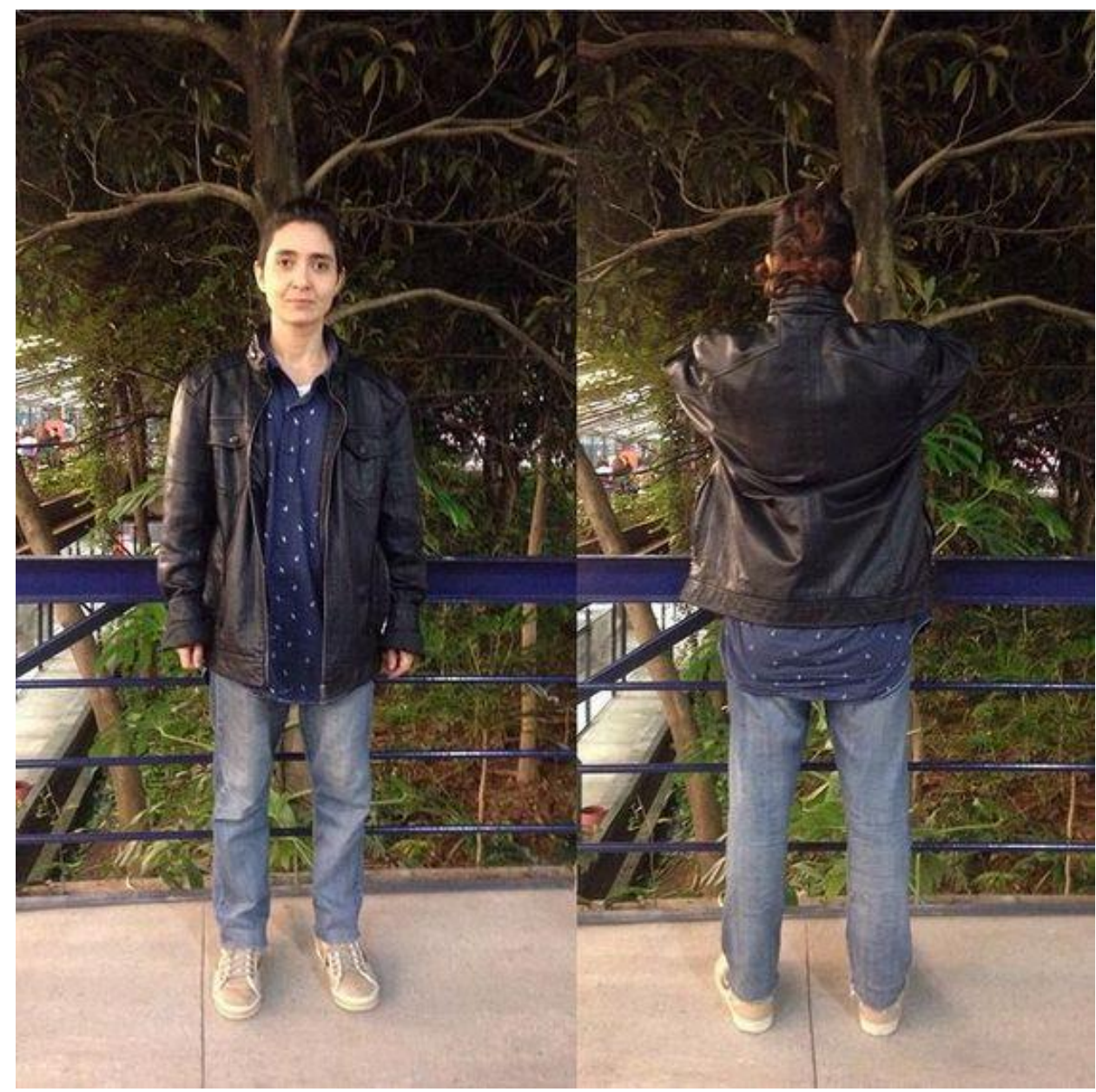

Fonte: Instagram do Projeto Desandar ${ }^{36}, 2017$.

Essa performatividade de gênero vai impactar o cotidiano da performer quando está vestida (descaracterizada) com os trajes dos participantes, veremos diversas construções de interpretação de gêneros possíveis dentro da performance Descaracterizar-se.

Em entrevista, a performer relata um momento de dificuldade de exercer sua função dentro de um trabalho de produção artística (Beatriz Cruz, entrevista, apêndice $A$ ):

Eu estava sendo vestida pelo Rodrigo, homem cis hetero, ele tem uma roupa de menino clássico: calça jeans, camisa e jaqueta (fazia frio),

${ }^{36}$ Disponível em: https://www.instagram.com/p/BUwjy80A7NK/?utm source=ig web copy link. Acesso em 15 jan. 2021. 
tudo um pouco mais larguinho, ele tem um cabelinho mais pra trás, com umas entradas, então eu punha o meu cabelo bem pra trás assim e ia. Nesse momento, eu estava fazendo uma produção grande de um grupo de Portugal que estava aqui, e foi muito difícil. Eu fiz a produção prévia, vestida de Rodrigo, então teve uma vez que fui pedir apoio num restaurante, e tinha uma questão do gênero muito forte. Uma coisa é eu era uma mulher, vestida como um homem, performando o que é dito masculino, pouco sedimentado no meu corpo aquilo. E eu uso do que é dito feminilidade, do que é ensinado pra gente, totalmente pra fazer produção, ainda mais para conseguir um apoio. E eu não conseguia falar. Lembro que fiquei sem palavras, não conseguia me encontrar ali, o cara olhando pra minha cara. Falei meio aos trancos e barrancos, obviamente não consegui o apoio, e aí isso foi meio sério, nesse período decidi que ia só ligar pros lugares. Na semana seguinte, outra etapa da produção, eu estava com a Talita, que era um outro oposto, batom o tempo inteiro, me lembro até de um espanto das pessoas, nesse trabalho (do grupo de Portugal), fiquei com eles uma semana, então eles me conheceram como ela, Talita, e logo no começo, como eu não conhecia ninguém, não sabiam que eu estava fazendo isso, isso era legal 'você é assim'. Marco, que era quem tinha me chamado, até falou 'nossa, gostei desse seu novo visual', eu não falei nada pra ele, não vou falar, deixa, eu também estava achando interessante estar nesse outro lugar...

Quando questionada se considera o chamado gênero feminino (categorizado por um suposto senso comum) mais atento em relação ao outro em suas escolhas, Cruz vai nos dizer que não considera, mas talvez a feminilidade possa sim ter um arcabouço maior de opções, "um conjunto de coisas muito maior, um conjunto de variedades, tipos de roupa, tipologias" (Beatriz Cruz, entrevista, apêndice A), e que por sua experiência, parece que tal aspecto depende muito mais de expressão de identidades do que expressão do gênero em si.

Definitivamente a segurança é uma preocupação do vestir feminino. $\mathrm{Na}$ entrevista, Cruz relata uma única vez em que não usou um traje de alguma troca, em razão do horário em que estaria exposta usando aquela indumentária. A segurança será também uma preocupação relatada por outro participante, como nos conta Cruz (2017): 
Elx diz que de uns tempos pra cá está sentindo uma repressão ao vestir essas composições - vê-las em mim promovem um certo alívio - elx fala de uma repressão muito forte - imagino eu ligada a preconceitos e fundamentalismos que afloram nos tempos atuais - não sofro isso penso no corpo delx em risco permanente - comigo, há estranhamento, mas não há um risco real - tem a ver com o local onde moramos, diz elx - não tenho dúvida - centro $x$ extremo da Zona Norte - quando elx passou uns tempos aqui comigo disse que experimentou uma liberdade maior - diferentes contextos - diferentes formas de existir tônus da coragem - tônus do despojamento - tônus da criação de si tenho um lampejo de querer permanecer com ele - em seguida, uma vontade de estar com minhas roupas - por fim, um desejo de passar muitos dias pelada - todos os sentimentos juntos - choro - me sinto também aliviada - separo roupas minhas para serem recortadas por elx. (Instagram do Projeto Desandar, CRUZ, 2017)

Uma clara percepção de como estão dispostas tais diferenças em nossa sociedade é como a rede social vai perseguir - e considerar como imprópria uma imagem em que a performer usa um traje de banho como seria usado pela pessoa com quem está ocorrendo a troca: calção de banho sem cobertura da parte superior do corpo. A imagem (figura 10) é denunciada e censurada pela rede social. 
Figura 10 - Censura da rede social

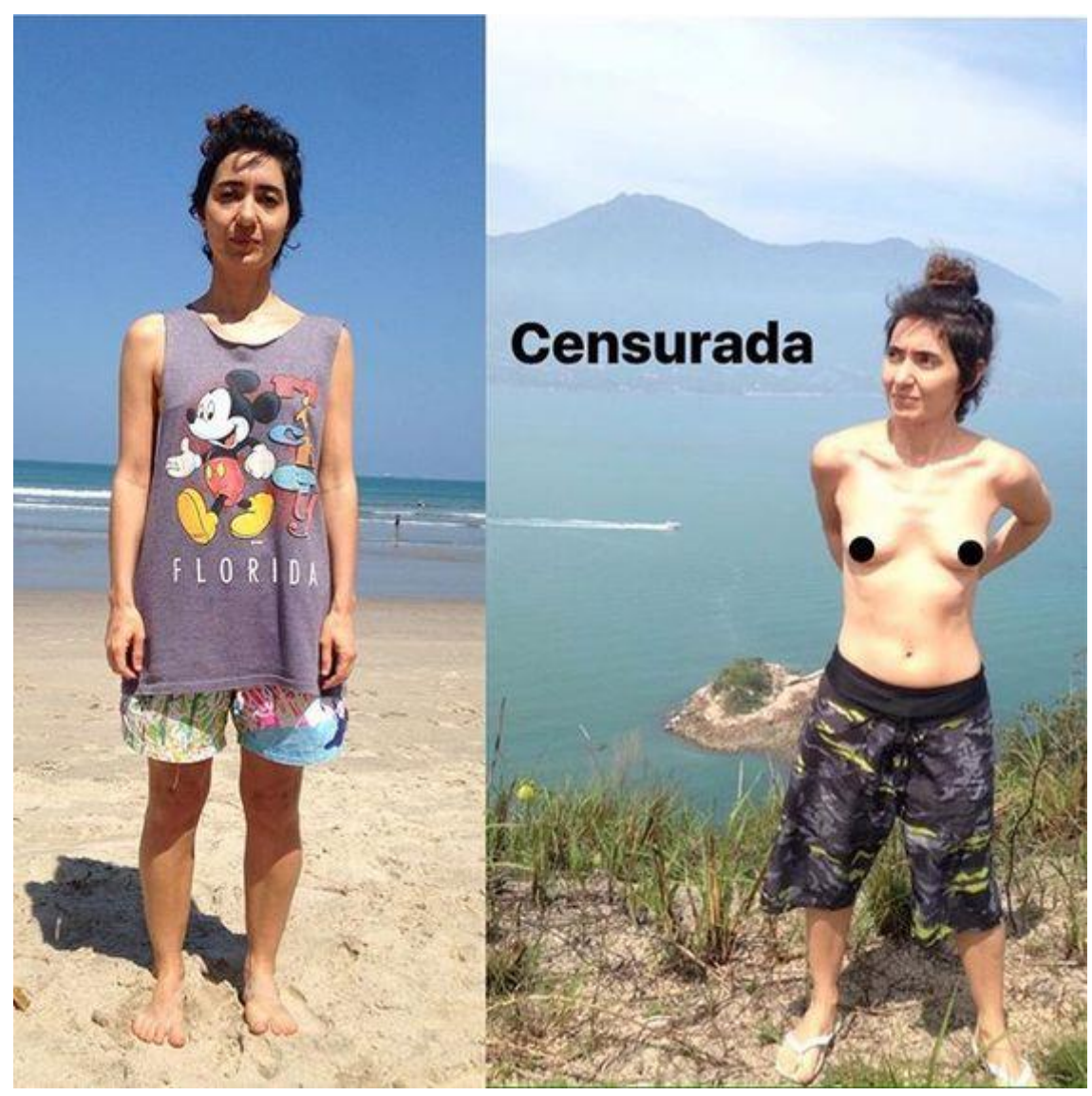

Fonte: Instagram do Projeto Desandar ${ }^{37}, 2017$.

\subsection{Roupa interior e subjetividade}

Não fazia parte do combinado, porém alguns participantes escolheram inserir roupas interiores, como calcinhas, sutiãs e cuecas dentro das peças selecionadas para troca. Nossa sociedade parece considerar a roupa intima como algo muito definidor do gênero, e um dos depoimentos de Cruz (2017) inclui uma epifania sobre esse uso de peças de outra pessoa (figura 11), algo que não necessariamente está a mostra:

(...) fui lavar a cueca de ontem e a calcinha de dois dias atrás - opostos

- renda x algodão - aliás e que algodão macio - que desenho

37 Disponível em: https://www.instagram.com/p/BY4j9aagUh8/?utm source=ig web copy link. Acesso em 08 jun. 2020. 
interessante ela faz no meu corpo - preto x rosa - só faltava a cueca ser azul para ser representação pronta do que é dito masculino e feminino - enquanto esfregava os dois tecidos tive um daqueles momentos epifânicos da Clarice Lispector - sabe quando o mundo pára e tudo ou nada fazem sentido - dessa vez foi para o nada - em que momento as caixinhas de homens e mulheres foram tão distanciadas. (Instagram do Projeto Desandar, CRUZ, 2017)

Figura 11 - Roupas intimas no varal.

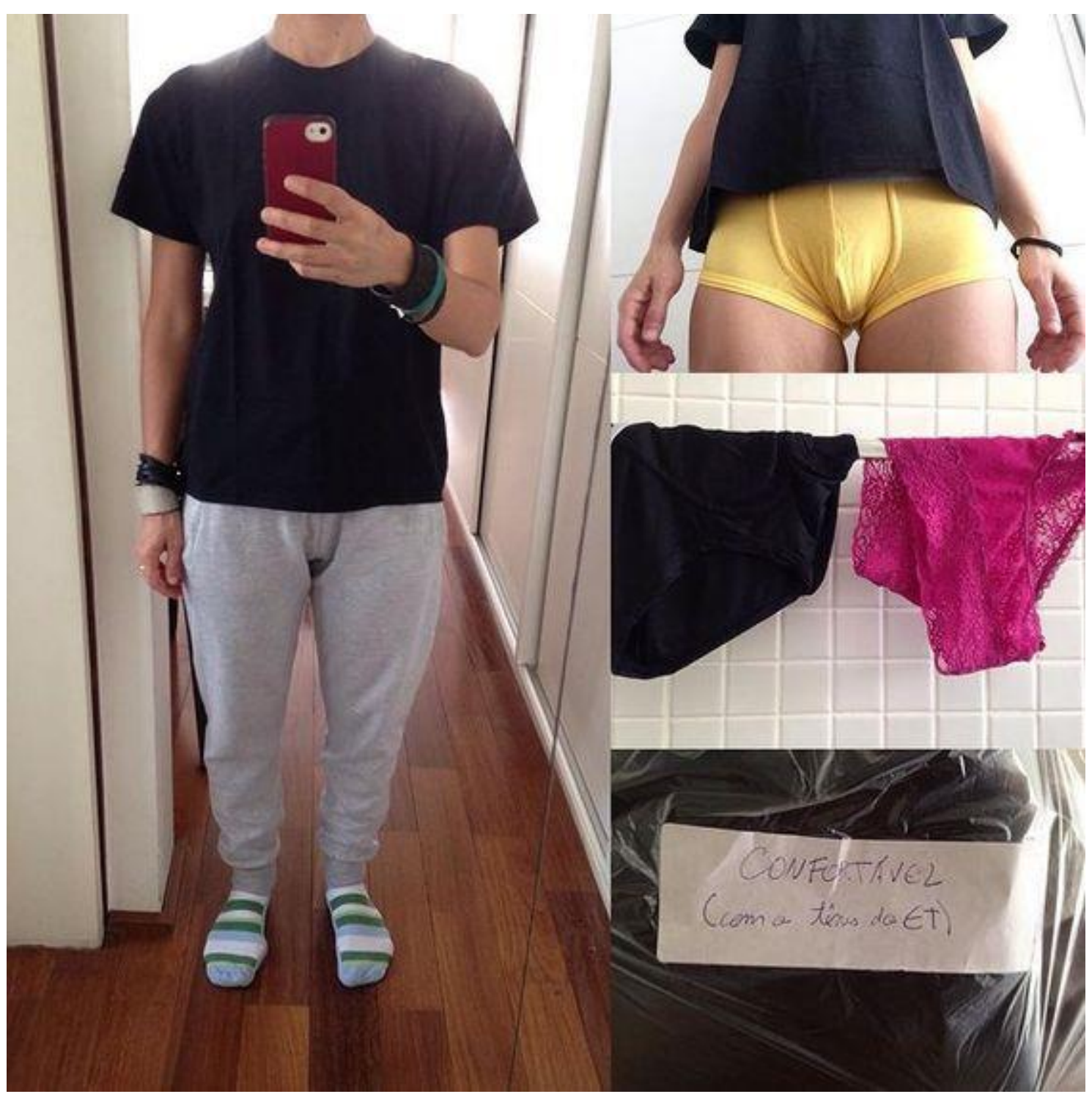

Fonte: Instagram do Projeto Desandar ${ }^{38}, 2017$.

https://www.instagram.com/p/BZIm9LRAAVP/?utm source=ig web copy link. Acesso em 06 jan. 2021. 


\subsection{Feminilidade exacerbada}

Veremos casos em que uma chamada feminilidade é exagerada nas subjetividades vestidas, onde existe um grande arcabouço de trajes, acessórios, maquiagem. Um desses casos é a participação de um homem cisgênero ${ }^{39}$ que realiza uma performance como Drag Queen. Assim como os demais trajes daquele participante, Cruz vai vestir (figura 12) também o traje de Drag Queen, incluído por ele neste acervo de indumentária na composição daquela troca. A figura da Drag, embora seja também performada por mulheres, é caracterizada por um "exagero artificial da feminilidade" (BUTLER, 2010, p. 9) e talvez por isso gere certo estranhamento quando uma audiência observa uma mulher cisgênero performando esse contexto, fora de uma cena artística ou performática.

${ }^{39}$ A palavra cisgênero (do latim cis significa do mesmo lado) é atribuída ao indivíduo quando sua identidade de gênero está em consonância com o gênero que lhe foi atribuído ao nascer. Disponível em: https://www.labeurb.unicamp.br/endici/index.php? $r=v e r b e t e \% 2 F v i e w \& i d=80$. Acesso em: 04 jan. 2021. 
Figura 12 - Cruz caracterizada como Drag Queen.

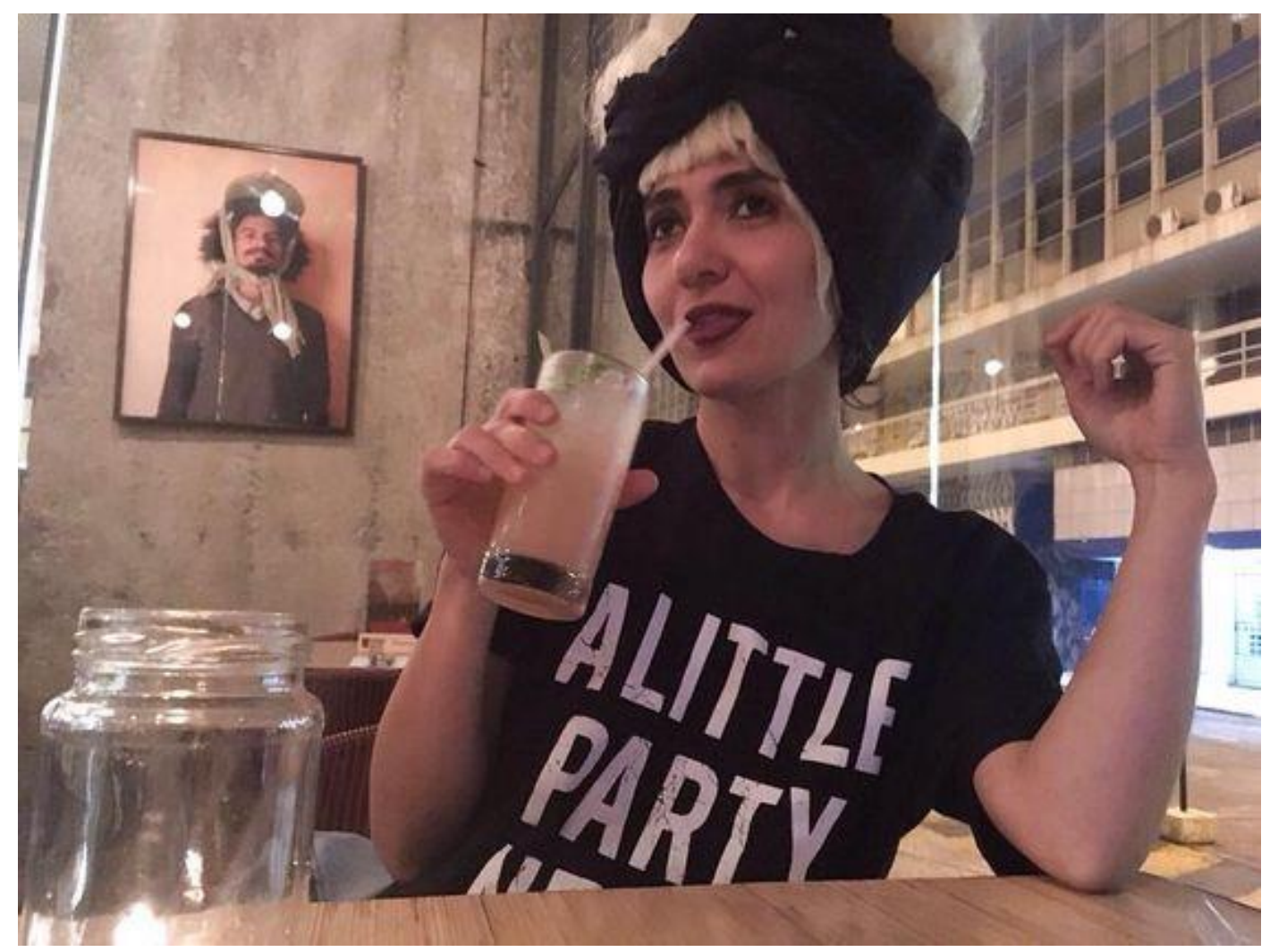

Fonte: Instagram do Projeto Desandarº, 2017.

\subsection{A não escolha}

Até quando existe o argumento de não pensar na roupa, cada escolha é, sim, milimetricamente decidida, como na troca com o também performer Márcio (figura 13), que nas palavras de Cruz (Beatriz Cruz, entrevista, apêndice A):

(...) a escolha dele foi muito precisa, escolhi essa blusa porque ela $x$, tinham coisas muito profundas sobre cada coisa, sobre cada escolha, uma história das peças, e vinha com muita camiseta de banda, camisetas históricas, então essa camiseta eu tenho desde tanto, ainda jun. 2020. 
que 0 visual quando você vê na rua poderia parecer super desencanado, na verdade não era, nunca é.

Figura 13 - A moda e o novo homem

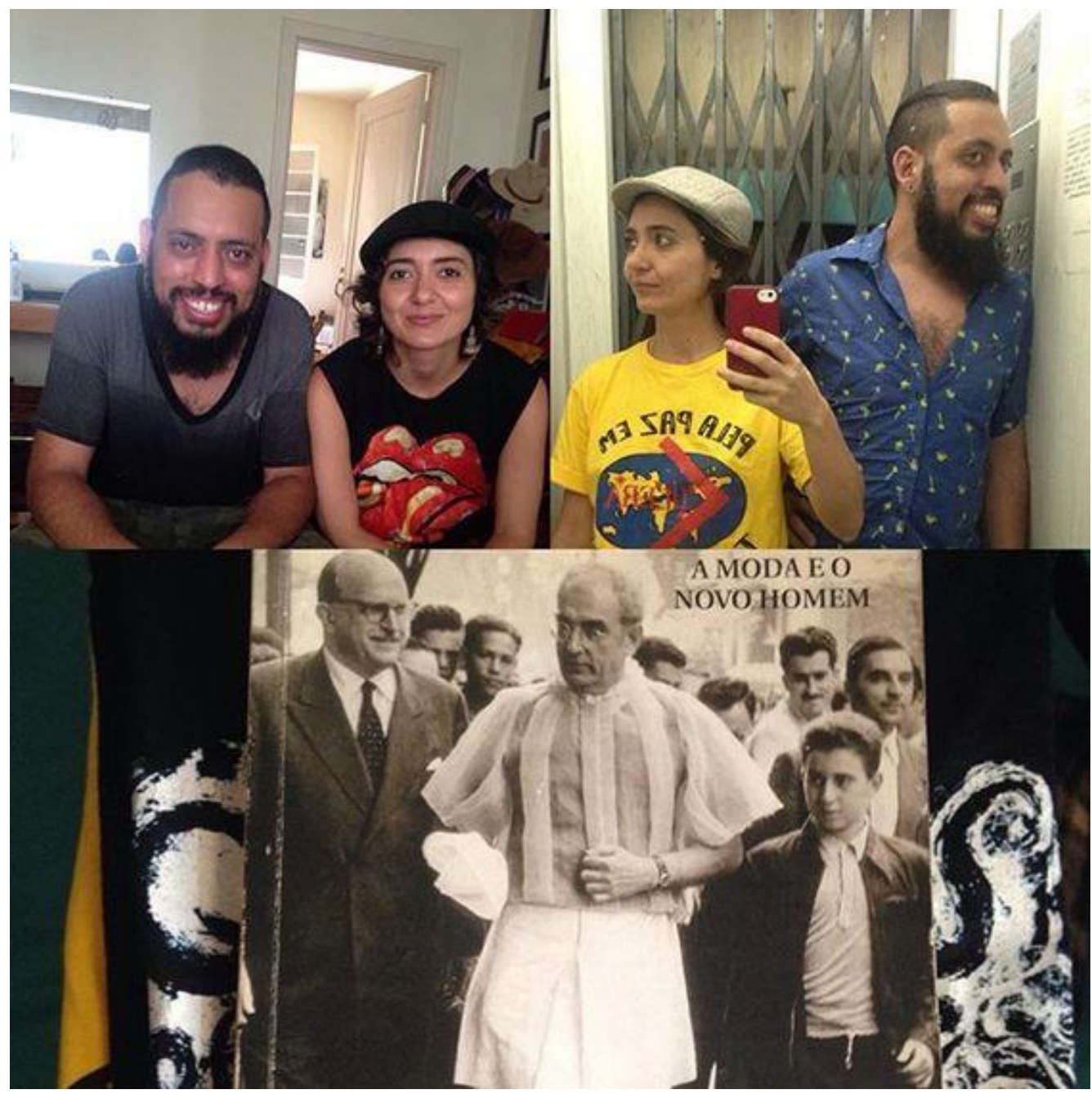

Fonte: Instagram do Projeto Desandar ${ }^{41}, 2017$.

Ao analisarmos esta opção muito pronunciada e alardeada como uma não escolha, notamos outro traje que faz surgir esta ideia com muita potência, ou seja, onde existe uma busca de um caráter de invisibilidade, de se mostrar como não escolha, e não por opção do indivíduo que faz uso do traje em questão. 08 jun. 2020. 


\title{
2.7 Uniforme como invisibilidade da subjetividade
}

Em pelo menos duas trocas, havia uma forte questão: o uso de uniforme profissional. A performer comenta durante a entrevista que existe uma intermitência em suas ocupações como artista, o que confere certa maleabilidade em sua escolha de trajes, forte contraste com o profissional que tem seu leque de opções limitado ao que é definido por uma empresa ou instituição. Disse Cruz:

\begin{abstract}
Você ter que estar muito tempo da sua vida igual, da mesma maneira, com a mesma cor, o mesmo tecido, as vezes é um tecido que não te agrada e tal, mas também tinha o como você tem que estar com esta roupa, você tem que estar maquiada, com a unha cortada e feita, você tem que estar com o cabelo preso, isso eu acho mais forte do que aquilo que o uniforme traz. Porque não é só a roupa, é um modo de agir, um modo de se apresentar. (Beatriz Cruz, entrevista, apêndice A)
\end{abstract}

Essa descaracterização que o uniforme proporciona é muito forte na população carcerária. Cruz comenta que desde 2014, trabalha em um projeto com as mulheres encarceradas, chamado Mulheres Possíveis: corpo, gênero e encarceramento ${ }^{42}$, onde essa questão com a roupa é muito forte. Em uma das trocas, ao usar uma calça amarela, a performer é barrada ao chegar para o trabalho na Penitenciária Feminina, já que a cor, junto com tons de bege, é de uso das internas.

A pessoa fora do ambiente do uniforme não pertence ao pacto silencioso de invisibilidade. Uma vez fora daquele ambiente específico, existe um olhar de estranhamento, de questionar por que aquela pessoa está usando aquele traje fora daquele ambiente, ou ainda mesmo chamar atenção, como quando detentos são vistos trabalhando fora do país das calças bege ${ }^{43}$, prontamente identificados como presidiários. Dentro da cena correta, é inclusive comum que o uniforme seja vestido quando se chega ao ambiente profissional, até como regra laboral

\footnotetext{
${ }^{42}$ Site do projeto disponível em:https://www.itaucultural.org.br/mulheres-possiveis-corpo-generoe-encarceramento. Acesso em: 20 jun.2020.

${ }^{43}$ Letra de música do álbum "Sobrevivendo no Inferno", da banda Racionais MCs, transformado em livro em 2018. Racionais Mc's Sobrevivendo no Inferno, 2018, Companhia das Letras.
} 
em alguns trabalhos, nem sempre o trabalhador pode ou deve usar o uniforme em outros ambientes que não o profissional.

O uniforme profissional como obrigação vestimentar pode inclusive ter algum impacto na saúde mental do trabalhador, mas sobretudo, na expressão de sua subjetividade. É o caso de uma das trocas, bastante impactante para a performer "(...) ela me deu um dos uniformes para a performance, o outro ela estava usando, mas deu trocas de roupa que ela usa quando não está trabalhando, 'uso pouco, porque passo muito tempo trabalhando'. (Beatriz Cruz, entrevista, apêndice A).

Impacto que também podemos notar neste outro relato de Cruz (2017) sobre o projeto:

$3^{\circ}$ dia - como ela se veste para ir trabalhar - quando o que você faz exige que você tenha outras escolhas - uniforme - a instrução é que você pareça confiável e asseada para o ambiente de uma farmácia ela leva o jaleco na bolsa e coloca lá - vai com a base, sem pulseiras e colares - maquiagem básica - batom opaco - coloquei meu cabelo pra trás pra dialogar - mas usei para ir até o local onde tinha uma reunião - não que não estivesse trabalhando em casa, é que temos naturezas de trabalho muito distintas - parei antes para imprimir alguns materiais - fui num lugar que sempre vou, atendentes habituais - pude acompanhar o olhar de um deles - de olho no logotipo - depois no meu rosto - olhos de interrogação, mas as palavras não vieram - nem dúvidas, nem exclamações - deixei quieto - permaneci quieta observando o movimento do pensamento - no metrô encontro algumas enfermeiras também de uniforme, me junto a elas, olhamos nossos logotipos e sorrimos - identificação - será que estão indo ou voltando? - como estariam vestidas sem uniforme? - permaneço novamente quieta e pensando - começo a olhar para seus corpos e imaginar possibilidades - cores, texturas, formas - me lembro uma vez de entrar num supermercado e achar que tudo estava diferente - parecia o supermercado mas vivo e alegre que já entrei - segui fazendo o que precisava, tentando apreender essa atmosfera - quando cheguei no caixa me dei conta, todos os funcionários naquele dia estavam sem uniforme. (Instagram do projeto Desandar, CRUZ, 2017) 
Esta questão também vai aparecer em outra troca, onde mais uma vez, a empresa do trabalho fornece poucos trajes, e a performer acaba por receber trajes que a participante Alda (figura 14) não tem tempo de usar, por passar a maior parte de seu tempo em ambiente de trabalho.

Figura 14 - Composição com trajes da participante Alda

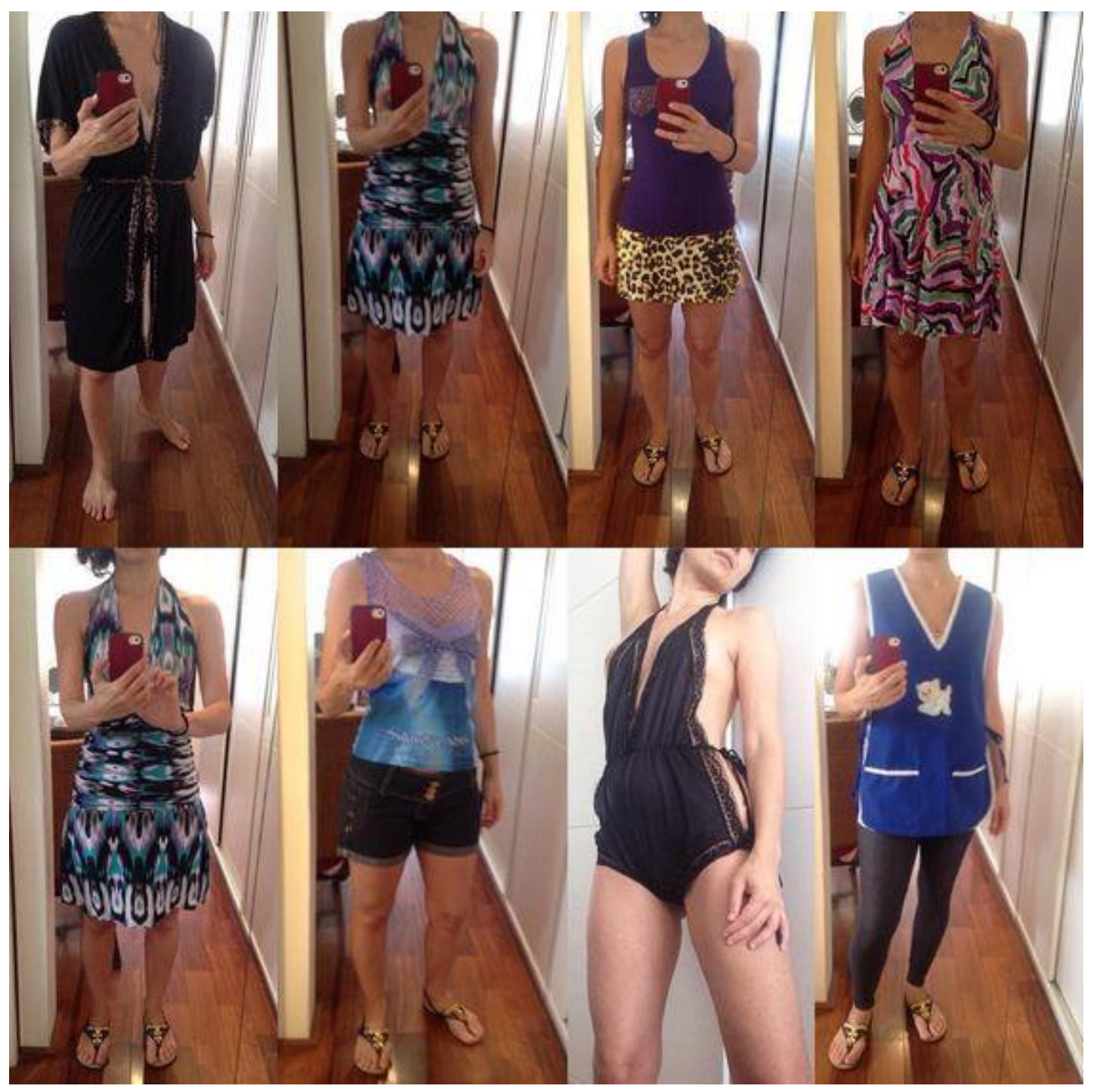

Fonte: Instagram do Projeto Desandar ${ }^{44}, 2017$. 


\subsection{Peças relevantes para troca}

Ao entrar em contato com o registro da performance, um dos primeiros questionamentos foi a questão dos tamanhos, que é muito relevante durante a criação de um traje de cena, onde geralmente 0 ator espera por este tipo de adequação. Para Cruz (entrevista, apêndice A), os calçados são um ponto muito importante da indumentária, imprimem modos de caminhar. Na entrevista, pergunto - e imagino ser uma dúvida recorrente de quem acompanhou a performance durante aquele ano - mas e os sapatos? Quando o tamanho era muito diferente, ela procurava por algo em seu acervo que desempenhasse 0 mesmo papel. Imagino que trocar calçados seja algo como perder o amparo das formas estáveis (SEQUEIRA, 2002), uma das maiores descaracterizações possíveis neste processo, a mudança no jeito de andar, de caminhar. Nesse sentido, a performer deixa essa escolha a critério do participante, e informa em uma chamada para as participações (PROJETO DESANDAR, 2018):

Algumas pessoas têm me perguntado como funciona 0 DESCARACTERIZAR-SE. É assim:

Convido pessoas para que me vistam com suas próprias roupas por uma semana.

Mulheres, homens, cis, trans, não-binários, qualquer altura, tamanho e composição.

Vou até a casa da pessoa (ou local de encontro que ela proponha). Ela me entrega roupa(s), sapato(s), acessório(s) para uma semana.

O critério de escolha das roupas e a quantidade dependem de cada um.

'O que gostaria que eu usasse?'

'O que usa com frequência?'

'Aquilo que mais te representa...'

E etc.

Pensar os critérios faz parte do jogo. 
Meu cabelo pode entrar no jogo.

Se a pessoa quiser que eu a descaracterize, é uma possibilidade.

Trocamos. Ambas temos cadernos de registro da experiência.

Quem quiser, escreve aqui.

Ou seja, tudo que a pessoa julgasse relevante para a troca entrava em jogo - dos sapatos a roupa interior, mesmo que o tamanho fosse muito discrepante do da performer. Existiu também, disponibilizada pela participante Estela, durante a performance, a questão do uso de uma órtese que inviabilizava o uso do braço direito (figura 15).

Figura 15 - Composição das vestimentas e uso de órtese da participante Estela.

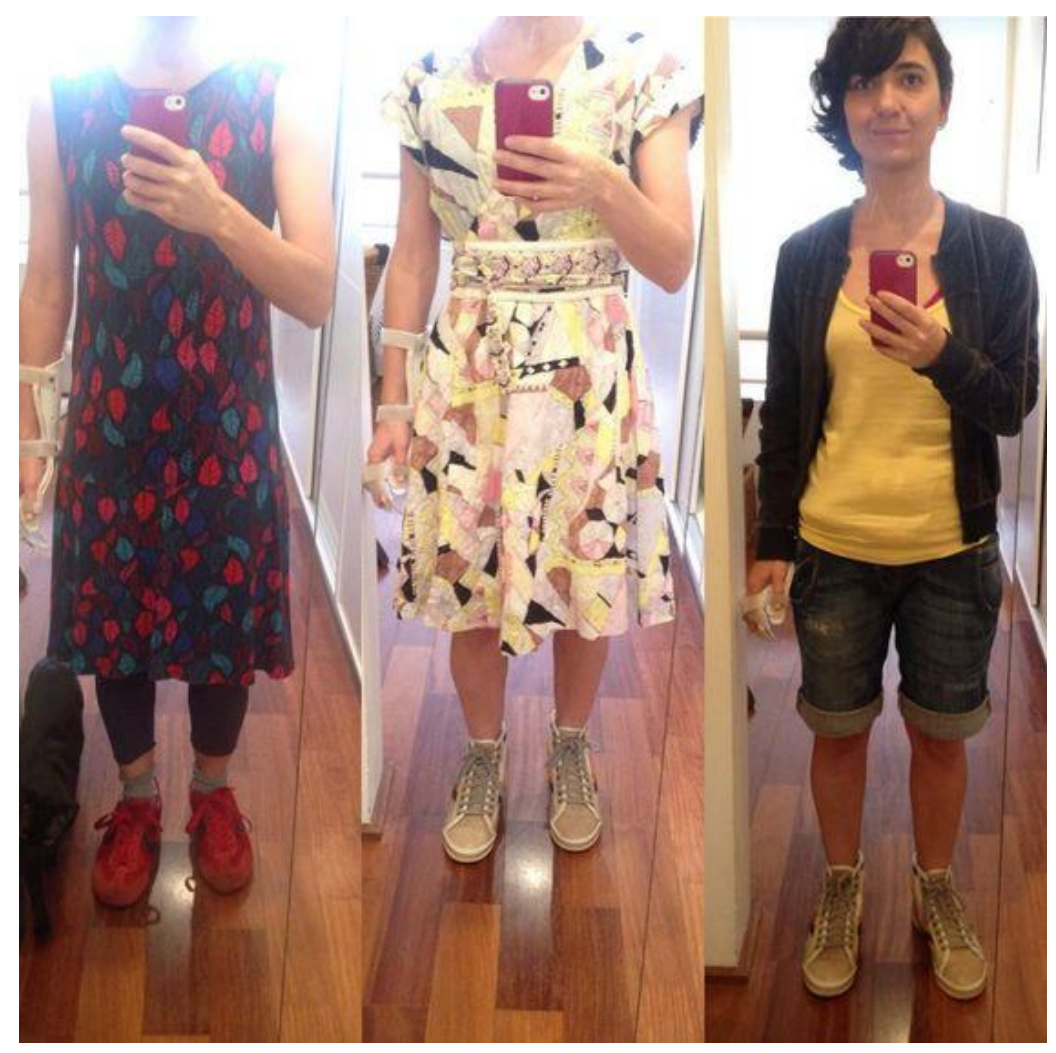

Fonte: Instagram do Projeto Desandar ${ }^{45}, 2018$. jun. 2019. 
Tanto na questão do uniforme quanto no uso de algo tão pessoal como uma órtese, existe uma demanda por explicações por parte de quem observa a performer ou entra em contato com ela cotidianamente. "Porque você usa isso, qual o diagnóstico?", podiam dizer transeuntes, um verdadeiro sufoco "de ter que se explicar o tempo todo e de fazer referências a uma origem, para só então, existir" (SEQUEIRA, 2002, p. 30). Vestir-se é uma parte desse sufoco, é um constante explicar-se sobre adequação (ou não) ao gênero designado, explicar o porquê daquela tala, daqueles óculos, muletas, ou mesmo das escolhas pessoais, uma justificativa subjetiva.

\subsection{Uma arqueologia da memória}

Silvia Fernandes (2010), em artigo onde fala sobre o trabalho de um diretor de teatro brasileiro, comenta sobre a semelhança com o trabalho de um arqueólogo, o que imediatamente nos leva a pensar em uma frase presente na exposição (figura 16) Descaracterizar-se, em 2018, que também está presente em registros do projeto na rede social.

Figura 16 - Frase na exposição

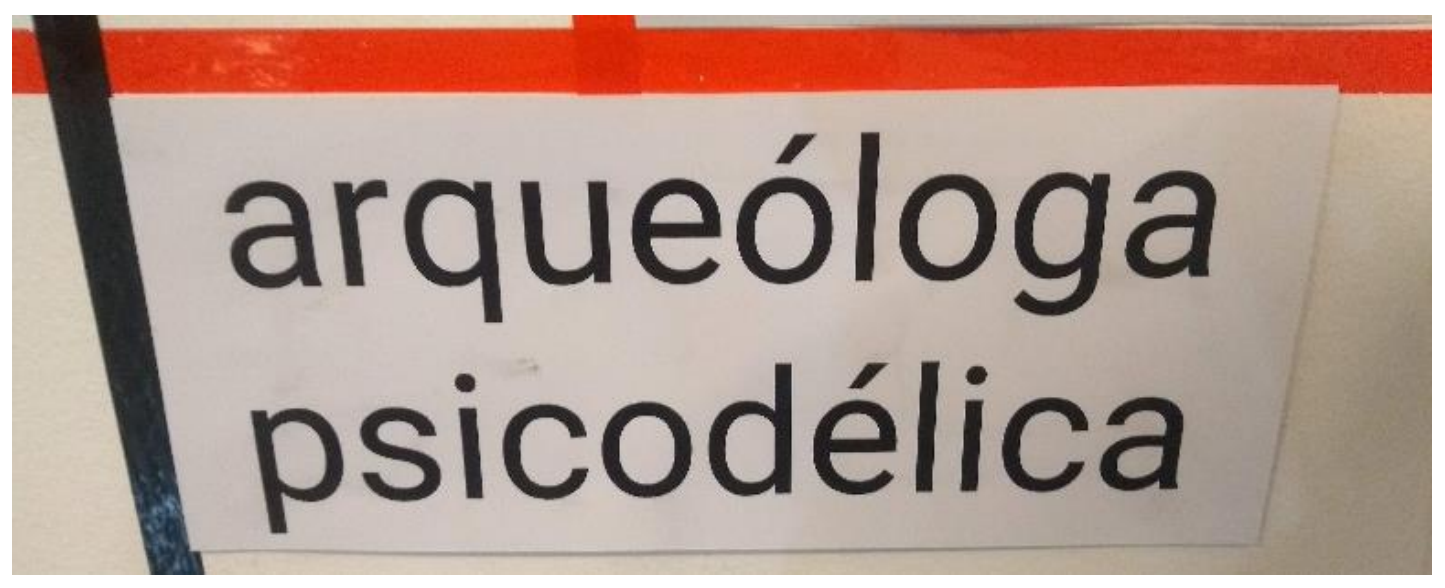

Fonte: acervo da autora, 2018. 
Usar o traje como dispositivo material para ação performativa não deixa de ser arqueologia, de nos fazer acessar memórias e ancestralidades, montando uma verdadeira reconstituição de memórias individuais e coletivas:

\begin{abstract}
Imagine-se um arqueólogo querendo reconstruir, a partir de fragmentos pequenos, um vaso antigo. É preciso mais que cuidado e atenção com esses cacos; é preciso compreender o sentido que o vaso tinha para o povo a quem pertenceu. A que função servia na vida daquelas pessoas? Temos que penetrar nas noções que as orientavam, fazer um reconhecimento de suas necessidades, ouvir o que já não é audível. Então recomporemos o vaso e conheceremos se foi doméstico, ritual, floral... (BOSI, 1994, p. 336)
\end{abstract}

Identificamos nos registros de Cruz significados e necessidades dos donos daqueles trajes, os porquês de quem os vestiu. Nesse sentido, nos parece relevante que a performer nos conte sobre a primeira convidada para a troca dos trajes (Beatriz Cruz, entrevista, apêndice A):

Logo pensei que seria interessante começar com minha mãe, que foi a pessoa que primeiro me vestiu. Durante o Descaracterizar-se, com algumas pessoas e sobretudo as que tem filhos, vinha muito essa reflexão que nos primeiros anos de vida, durante algum tempo, você é vestido.

Nesse momento inicial da vida, as pessoas têm suas escolhas feitas por outras pessoas, e vão então construindo suas subjetividades ao longo de sua formação, sendo influenciadas - ou não - por essas escolhas do outro.

Questiono a performer sobre quais trocas a afetaram mais, e Cruz (entrevista, apêndice $A$ ) responde: "Pessoas muito próximas me afetavam e pessoas que traziam um referencial muito diferente também me afetaram muito". A performance começa com pessoas muito próximas, da mesma família, até chegar em desconhecidos que entram em contato via rede social - essa autora inclusive foi uma delas. Entre estranhezas e pertencimentos, a performance se configura como "um susto ficar assim, desfeito" (SEQUEIRA, 2002, p. 33). Existe um impacto afetivo, mas também um impacto físico, que será descrito nos 
registros da performance, uma vez que o traje envolve nossa pele, maior órgão do corpo. Cruz (entrevista, apêndice A) vai nos dizer que "os pequenos relatos dão conta de alguma maneira porque se você os lê na íntegra, consegue acompanhar essa flutuação de sensações e estados".

$\mathrm{Na}$ figura 17, vemos a autora dessa pesquisa e a performer, descaracterizadas, com suas vestes trocadas. É, sim, impressionante, um susto, vermos nossa subjetividade apropriada por outra pessoa. Não se trata apenas de uma homenagem que brinda um passado ou memória distante, como veremos no capítulo seguinte. Em Descaracterizar-se, podemos ver em tempo real a subjetividade espelhada no outro, ao vivo ou via rede social. E ver no outro essas características pode deixar mais claro para o indivíduo que participa da troca, que não apenas seus trajes, mas sua expressão no mundo, nos faz reconhecer: "sou feito disso".

Figura 17 - Descaracterizada

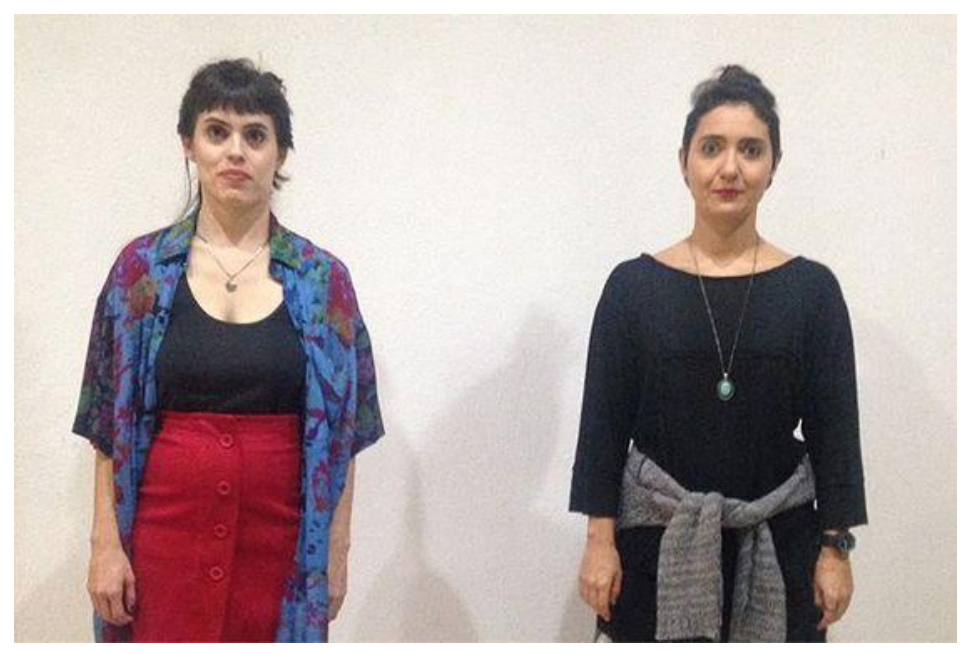

Fonte: Instagram do Projeto Desandar ${ }^{46}, 2018$.

Nesse momento da troca, emergem as memórias da escolha daqueles trajes: estava frio, então esta autora colocou meia-calça. A saia evoca um momento passado de andanças, que seria repetido naquele dia, por meio de um transporte que ela ainda não sabia qual seria, e de andar por ruas desconhecidas. 
Toda essa memória também emerge nas demais trocas em Descaracterizar-se, quando os trajes podem vir carregados de "uma memória forte, às vezes é uma memória besta, do lugar onde você estava quando você comprou, ou quem te deu, ou o que ela passou" (Beatriz Cruz, entrevista, apêndice A). A performance e seus registros vão acessar e demonstrar essas memórias, mesmo que não obviamente. As pessoas participantes da troca vão querer ilustrar esses sentimentos, viam importância nisso, quem havia dado, qual a ocasião havia usado antes ou por quantas vezes, onde haviam estado, uma relação não apenas prática, mas também afetiva. Essa mesma autora trouxe isso à tona ao escolher o traje daquele dia.

Sim, vestimos memórias, nossas ou coletivas, e afirmamos isso em nossos trajes e nossa caracterização. 


\section{Capítulo 3 - Quando a criação de trajes encontra a memória}

Dizem: ah, mas memórias não são nem história, nem literatura. É só a vida, cheia de lixo e sem a limpeza feita pelas mãos do artista. (Svetlana Aleksévitch, A Guerra não tem rosto de mulher.) 
A memória pode vestir o traje da homenagem, ou de uma saudade muito grande, de algo vivido ou não vivido, pode nos assombrar, perseguir, cobrar, bem como nos alegrar e encantar, ser afloramento ou ressureição do passado. Acessar lembranças e percepções de tempos já passados não significa que não somos fortes o suficiente para seguir adiante, mas estas memórias nos cobram elaboração de seus significados. Mais que meras nostalgias, podem convocar histórias, vividas ou imaginadas. Nesse contexto a costura pode ser tanto ferramenta técnica quanto estratégia narrativa, uma maneira de entender nossas próprias histórias pessoais e percepções, ou mesmo as de outros, pelo menos aquelas com as quais nos identificamos, e guardamos: "Mal termina a percepção, as lembranças já começam a modificá-la: experiencias, hábitos, afetos, convenções vão trabalhar a matéria da memória" (BOSI, 1994, p. 340).

Neste capítulo, investigamos e aprofundamos relações entre memória e objetos têxteis, particularmente, trajes, a partir do projeto Memórias Vestidas: Reconstrução de Indumentária, realizado no ano de 2016, por uma dupla ${ }^{47}$ de figurinistas, Anna Theresa Kühl, autora dessa pesquisa, e Aline Barbosa da Cruz Prudente, hoje professora no SENAC Lapa Faustolo ${ }^{48}$, na cidade de São Paulo - SP. Neste projeto ocorreu um processo de encantamento com a alma das coisas - nesse caso, têxteis, e também uma investigação sobre o que foi chamado naquela ocasião de objetos afetivos. Ao olhar para o projeto, pudemos perceber possibilidades de atravessamentos entre vida e arte, por meio da recriação dos trajes a partir de memórias, elementos chave deste projeto artístico. Serão analisados materiais como registros fotográficos e depoimentos das participantes, parte integrante do projeto, publicados em endereço virtual após integrarem a exposição. Notaremos pontos de contato entre o projeto e processos de criação de figurino, que serão sublinhados.

O projeto analisado neste capítulo vai olhar para o crescente imaginário da memória ao longo da realização das atividades de sua programação. Interessante notar que durante esse período de realização, foram ouvidas muitas

\footnotetext{
47 De 2015 a 2018, a dupla compunha a iniciativa VID Estúdio Criativo, um empreendimento que unia então trabalhos de traje de cena, aulas e projetos de formação nas áreas de figurino e moda. Disponível em https://videstudiocriativo.blogspot.com/. Acesso em 01 de dez. de 2020.

${ }^{48}$ Esta unidade da escola técnica SENAC é especializada em moda, em especial modelagem, desenho de moda, história da moda, entre outros.
} 
vezes frases como "é assim mesmo, tocar pra frente, viver a vida". As memórias - de outros tempos ou de pessoas já falecidas - emergiam e emocionavam o tempo todo, vinham de registros orais, fotografias, trajes, têxteis ou mesmo de objetos pessoais ligados a estas memórias. Podemos ter uma ideia da diversidade dos objetos trazidos com a figura 18 , onde vemos um álbum de bordados, uma fotografia e um antigo ferro de passar:

Figura 18 - Objetos trazidos pela participante Teresa

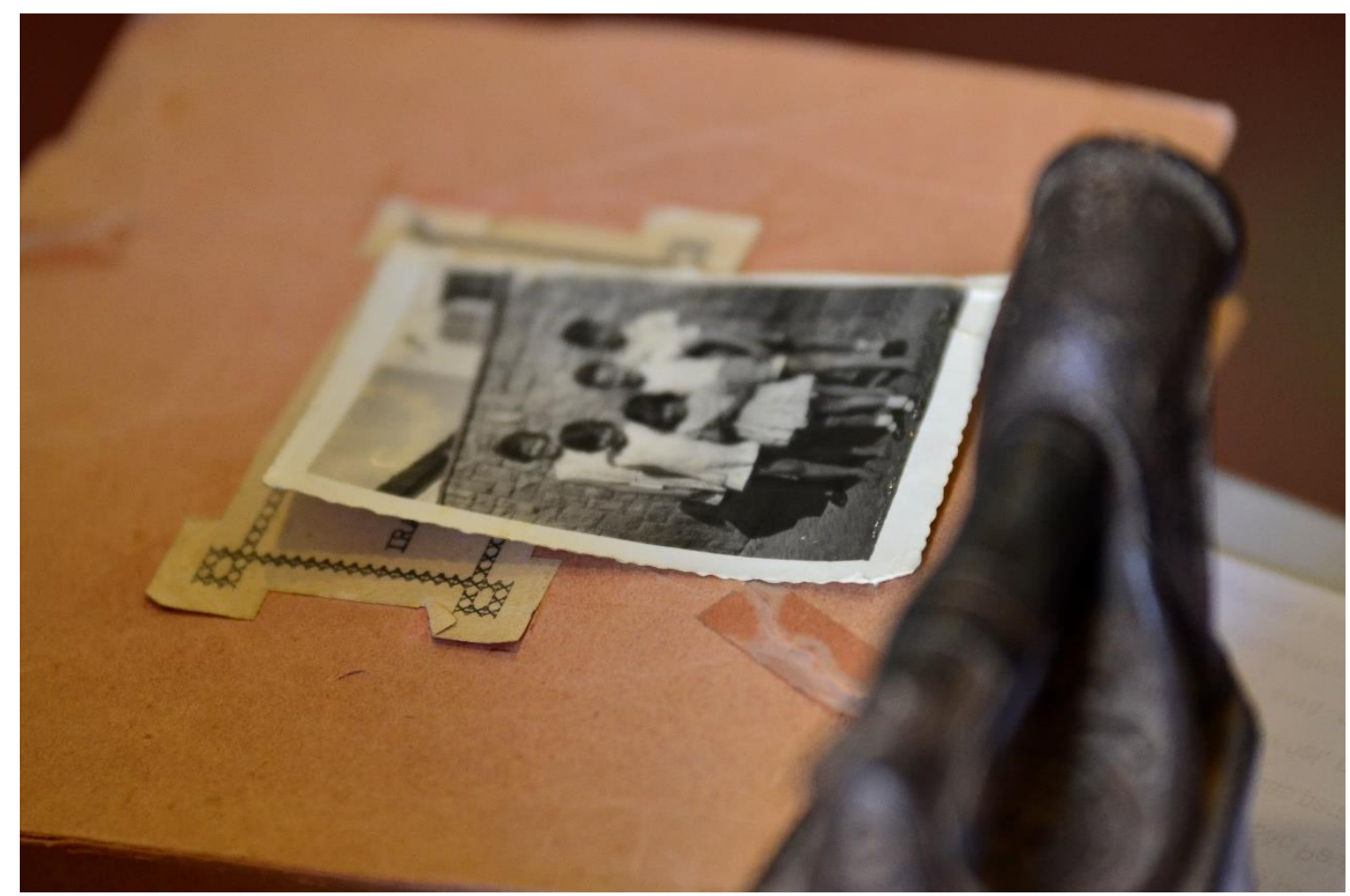

Foto: Maycon Soldan, 2016.

Para o processo de recriação dos trajes, podemos elaborar relações sobre o funcionamento da memória, que, traiçoeira e seletiva, pode funcionar analogamente à uma ilha de edição, sempre atravessada por rearticulações do imaginário, onde o passado é inventado a todo momento e, ao mesmo tempo, permite emergir algo similar a uma saudade de um futuro imaginário.

No contexto do projeto Memórias Vestidas, o imaginário e a memória permitiram o desenho e construção do traje - que se mostrou factível tanto como traje social e/ou de cena. A produção das roupas e os processos subsequentes de documentação, exposição, desfile e depoimentos foram os canais que possibilitaram às participantes a elaboração de suas lembranças. 


\subsection{Memórias do que veio antes}

A escolha pelo público idoso e do encontro de gerações que acontece no projeto Memórias Vestidas: Reconstrução de Indumentária não foi acidental. Um dos objetivos do projeto ${ }^{49}$ quando inscrito no edital da secretaria era incentivar esta convivência, tal como a justificativa apontava (disponível em anexo I):

\footnotetext{
Segundo o artigo "Hábitos Culturais dos Paulistas", publicado em julho deste ano (2015), a população idosa é considerada a mais excluída em termos de consumo cultural. Uma das principais motivações deste projeto é a geração de oportunidades para a convivência, fruição cultural e a valorização da memória de pessoas da terceira idade.
}

O encontro com guardiões do passado, um dos termos que Ecléa Bosi (1994) evoca ao falar da terceira idade, acontece antes da execução de Memórias Vestidas: Reconstrução de Indumentária, no ano de 2016. Duas experiências fizeram papel de ensaio antes dos encontros, aulas e confecções realizadas no projeto. Foram elas: a oficina Histórias Da Moda: Identidade e Consumo Consciente, realizada em janeiro daquele ano no SESC Campinas; e o projeto Costurando Histórias: Encontro de Gerações, contemplado pelo Programa de Ações Culturais (ProAC) Economia Criativa. Para registrar semelhanças desses dois momentos que depois podemos considerar como possíveis ensaios, descreveremos um pouco de seus processos ${ }^{50}$.

\subsection{Oficina Histórias Da Moda: Identidade e Consumo Consciente}

Com o projeto Memórias Vestidas já contemplado pela Secretaria de Cultura do Estado de São Paulo, as duas figurinistas responsáveis foram então chamadas para orientar uma oficina no SESC Campinas, em janeiro de 2016; sobre história da moda e consumo consciente como pontos de partida. Na oficina ocorreu um primeiro encontro com aquele que seria boa parte do público participante do Memórias Vestidas: Reconstrução de Indumentária: a terceira

\footnotetext{
49 Segundo o projeto inscrito ao Proac - Programa de Ações da Secretaria do Estado de São Paulo, da Secretaria de Cultura, no ano de 2015. Este projeto encontra-se no ANEXO I.

50Informações sobre esses dois projetos podem ser encontrados em: https://videstudiocriativo.blogspot.com/. Acesso em: 04 dez. 2020.
} 
idade. Este era o público-alvo daquela oficina ${ }^{51}$, que integrava o núcleo temático Trabalho Social com Idosos, dentro da programação de férias Avós e Netos. Diversas possibilidades de expressão a partir da moda puderam ser exploradas, além de discutir sobre o consumo de moda atual, possíveis tendências de sustentabilidade, consumo consciente e história da moda, como vemos na figura 19.

Figura 19 - A Oficina no SESC, em janeiro de 2016

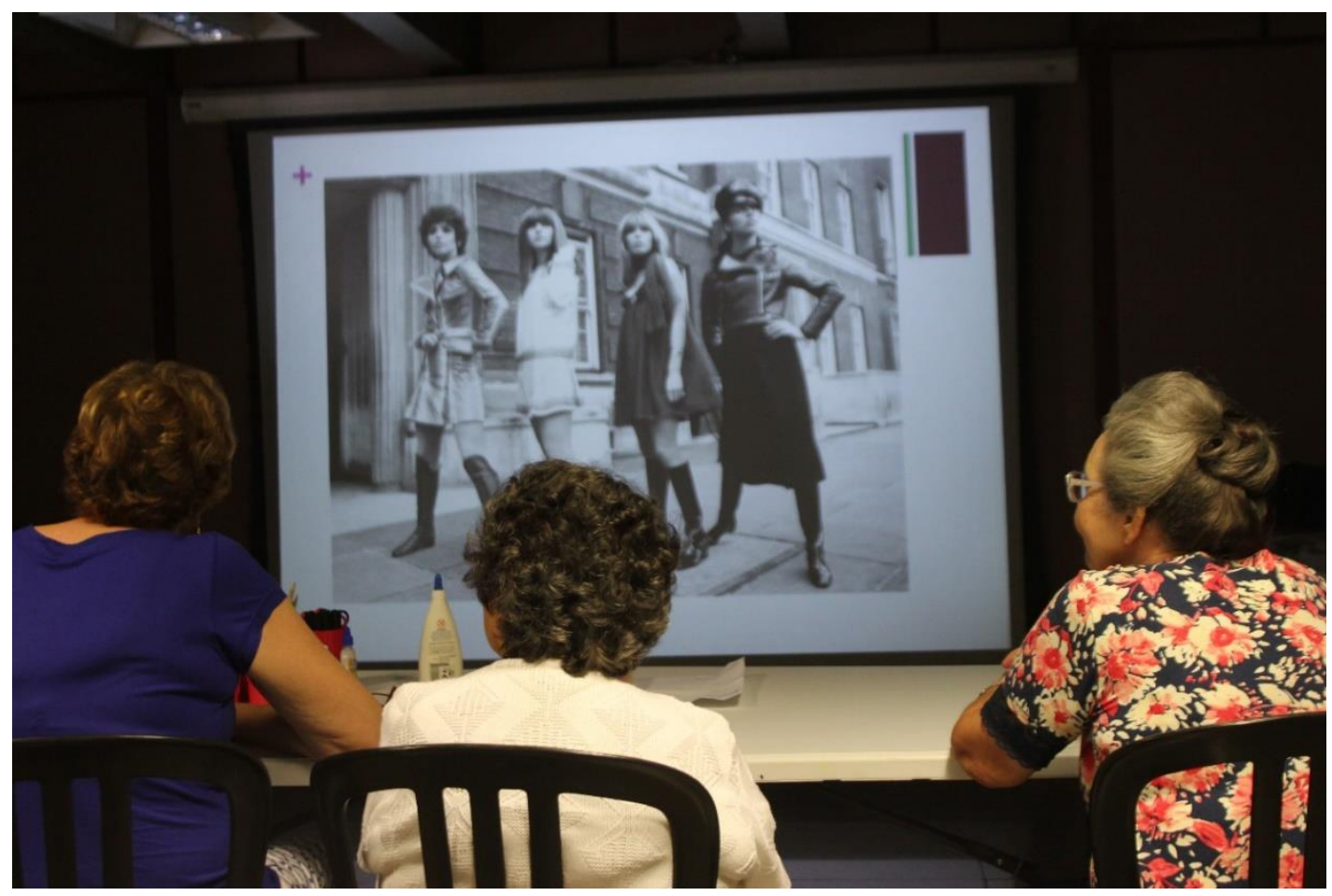

Foto: Aline Barbosa da Cruz Prudente, 2016.

A oficina se desenhou a partir de uma busca por conceitos de sustentabilidade, tendo um clube da troca como objetivo final. Antes disso, foram realizados exercícios de autoconhecimento, painéis de inspiração e análises de peças afetivas, oportunidade para mergulhos na história pessoal da indumentária de cada participante. A condução dessas histórias e memórias a partir de trajes moldou muito do que seria a programação do projeto Memórias Vestidas.

51 Oficina Histórias da moda: identidade e consumo consciente, realizada em janeiro de 2016, no SESC Campinas. Disponível em: https://videstudiocriativo.blogspot.com/2015/11/janeiro-de2016-oficina-historias-da.html. Acesso em 30 de out. de 2020. 


\subsection{Costurando Histórias: Encontro de Gerações}

Também em 2016, dessa vez já como ação fomentada pelo Proac, foi executado o projeto Costurando Histórias: encontro de gerações, que trabalhou com público da terceira idade, junto a jovens. Nesta oficina, a realização de trajes segue uma proposta mais livre, a partir da questão chave: Que histórias você veste ${ }^{52}$; em um sentido mais da imaginação do que de memória. Nesse projeto, ocorreu uma costura de conhecimentos, onde além das histórias de vida dos participantes, também surgiram figuras do imaginário, saídas de ficções autobiográficas que eram interpretadas por meio da criação dos trajes, como podemos ver na figura 20.

Figura 20 - Traje criado para o projeto

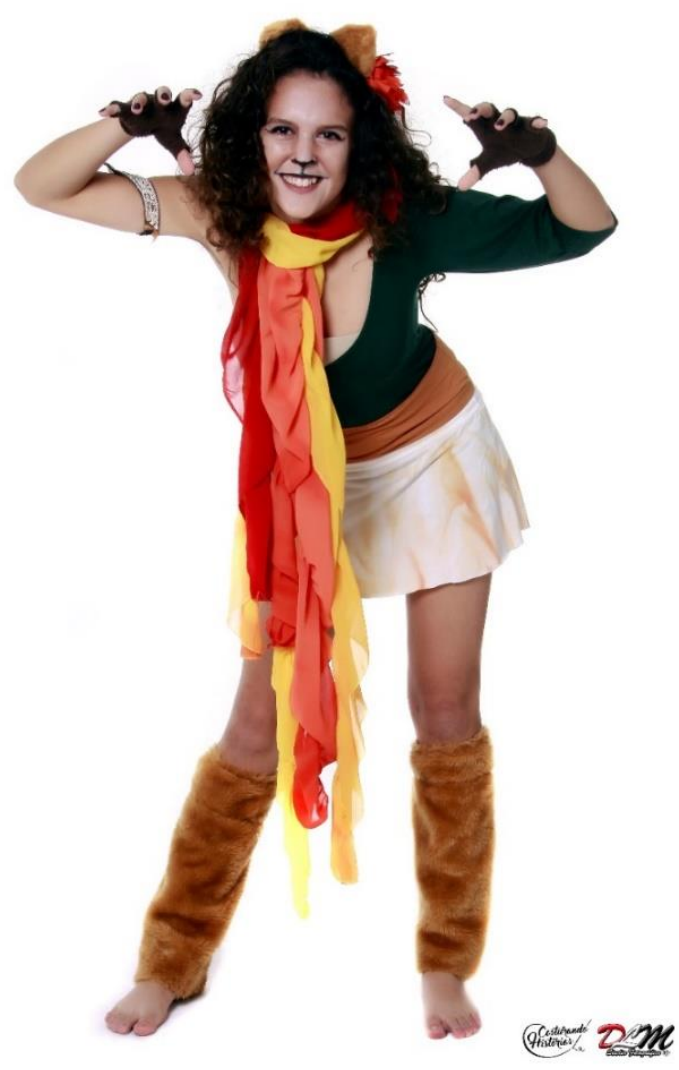

52 Informações no blog do projeto Costurando Histórias: Encontro de Gerações. Disponível em: https://costurandohistoriascampinas.blogspot.com/. Acesso em:28 out.2020. 
Foto: DLM Estúdio Fotografia e Cinema, 2016.

Os onze trajes do projeto foram realizados por pessoas entre 16 e 70 anos, que conviveram, trocaram experiências e visões de mundo. As trocas envolveram desde a história da moda com pessoas que viveram em épocas passadas até a criatividade contemporânea dos jovens.

Também havia uma exploração do que naquela época foi chamado de moda e sustentabilidade; materiais e resíduos têxteis foram ressignificados, tingidos, customizados, bordados. Muito do acervo dos participantes e das coordenadoras foi usado, além de peças de segunda mão garimpadas em bazares da região.

Este projeto aconteceu em período próximo ao Memórias Vestidas: Reconstrução de Indumentária, e diversas alunas, tanto do público jovem quanto da terceira idade, continuaram na próxima turma, do projeto seguinte. Estas duas atividades, a oficina no SESC e o projeto Costurando Histórias, puderam funcionar como laboratório de conteúdos e práticas para o próximo projeto, protagonista desse texto. Nesses dois contextos, questões de memória afetiva e expressão de subjetividades já estavam presentes, e foram então amadurecidas em Memórias Vestidas: Reconstrução de Indumentária.

\subsection{Enfim, vestir memórias}

O projeto teve origem na ideia de que a roupa é um elemento importante da memória, e na vontade de reconhecer e estudar história recente do trajar, junto a pessoas que viveram e vestiram trajes de outras épocas, em um passado recente.

Contemplado em 2015 pelo Edital de Artes Integradas do Programa de Ação Cultural (Proac) da Secretaria de Cultura do Estado de São Paulo, esse projeto abarcou as linguagens de artes visuais, fotografia e moda, e desenvolveu criações a partir da memória e valorização da história cultural das participantes inscritas. Contou com a colaboração de artistas de diversas linguagens, entre eles dois fotógrafos, uma professora de costura e modelagem e um designer e produtor audiovisual. A autoria do projeto foi das duas figurinistas já 
apresentadas, Aline Barbosa da Cruz Prudente e a autora desta pesquisa, Anna Theresa Kühl. O objetivo principal do projeto girou em torno da memória produzida pela indumentária, que seria então desenvolvida como uma obra de artes integradas, realizada em diversas etapas: aulas de história da moda, exercícios de criação e autoconhecimento, processo de criação e confecção de trajes, fotografias desses trajes vestidos por suas criadoras, desfile dos trajes, exposição das fotografias e registros gráficos do processo e a realização de quatro vídeos ${ }^{53}$ roteirizados a partir do registro audiovisual de cada fase do projeto. Aconteceu ainda, ao final do projeto, junto a abertura da exposição, um desfile em que as participantes vestiram os trajes. Não se tratou de uma encenação, mas aqui vamos considerar como uma performance, partindo de leitura de Richard Schechner (2003), teórico que olha para a performance de forma ampla, ao abordar também comportamentos cotidianos, ritualísticos, esportivos, entre outros. Argumentamos então que no caso de Memórias Vestidas: Reconstrução de Indumentária, nos deparamos com uma celebração de memórias cotidianas, que em algum momento foram performadas. Destacamos essa fala de Schechner (2003, p. 34) sobre comportamento restaurado que se relaciona com o contexto do projeto:

Um comportamento pode ser restaurado a partir de 'mim mesmo' em outro tempo ou estado psicológico - por exemplo, contando uma história ou encenando para amigos detalhes de um acontecimento traumático ou comemorativo.

Schechner vai dizer ainda que o comportamento, quando restaurado, pode ser então emoldurado, separado, aprimorado, guardado, resgatado, transmitido e transformado (Ibidem, p.35). Ao usarem os trajes durante a sessão de fotos e o desfile durante abertura da mostra fotográfica, as onze participantes, de certa maneira, recriam momentos a partir daquelas indumentárias, de maneira reelaborada. O desfile não foi apenas uma exibição das peças, podemos considerar que fez parte do processo de ressignificação e presentificação daquelas memórias. Tanto recriação quanto a reconstituição se 
apoiam na imaginação e na memória, gêmeas siamesas. Como nos diz a atriz Maria Alice Possani54 (2017, p. 53):

É necessário (será mesmo que ainda é?) dizer que entendemos memória como criação. O passado não é um lugar estável que se visita. A memória é espaço de permanente criação, fluxo que se atualiza na película que chamamos de presente. E, portanto, indissociável da imaginação. Toda memória é imaginada.

Bosi (1994, p. 17), a partir de suas investigações vai dizer que "na maior parte das vezes, lembrar não é reviver, mas refazer, reconstruir, repensar, com imagens e ideias de hoje, as experiências do passado". Como vemos na figura 21, que ilustra a exposição final do projeto Memórias Vestidas: Reconstrução de Indumentária, essas memórias são recriadas, reimaginadas e reelaboradas como trajes, desfiladas por suas criadoras, além dos textos escritos por elas, presentes na exposição junto as fotos.

${ }^{54}$ Maria Alice Possani é atriz do Grupo Matula Teatro, que inicia a trajetória no ano 2000, a partir de trabalhos de mímeses coporea. Nos processos do grupo, a imaginação e a memória são protagonistas. Além da tese de doutorado da atriz estar entre nossas referências bibliográficas, ela faz parte do elenco do espetáculo teatral que é citado na conclusão deste trabalho. 


\section{Figura 21 - Exposição dos trajes}

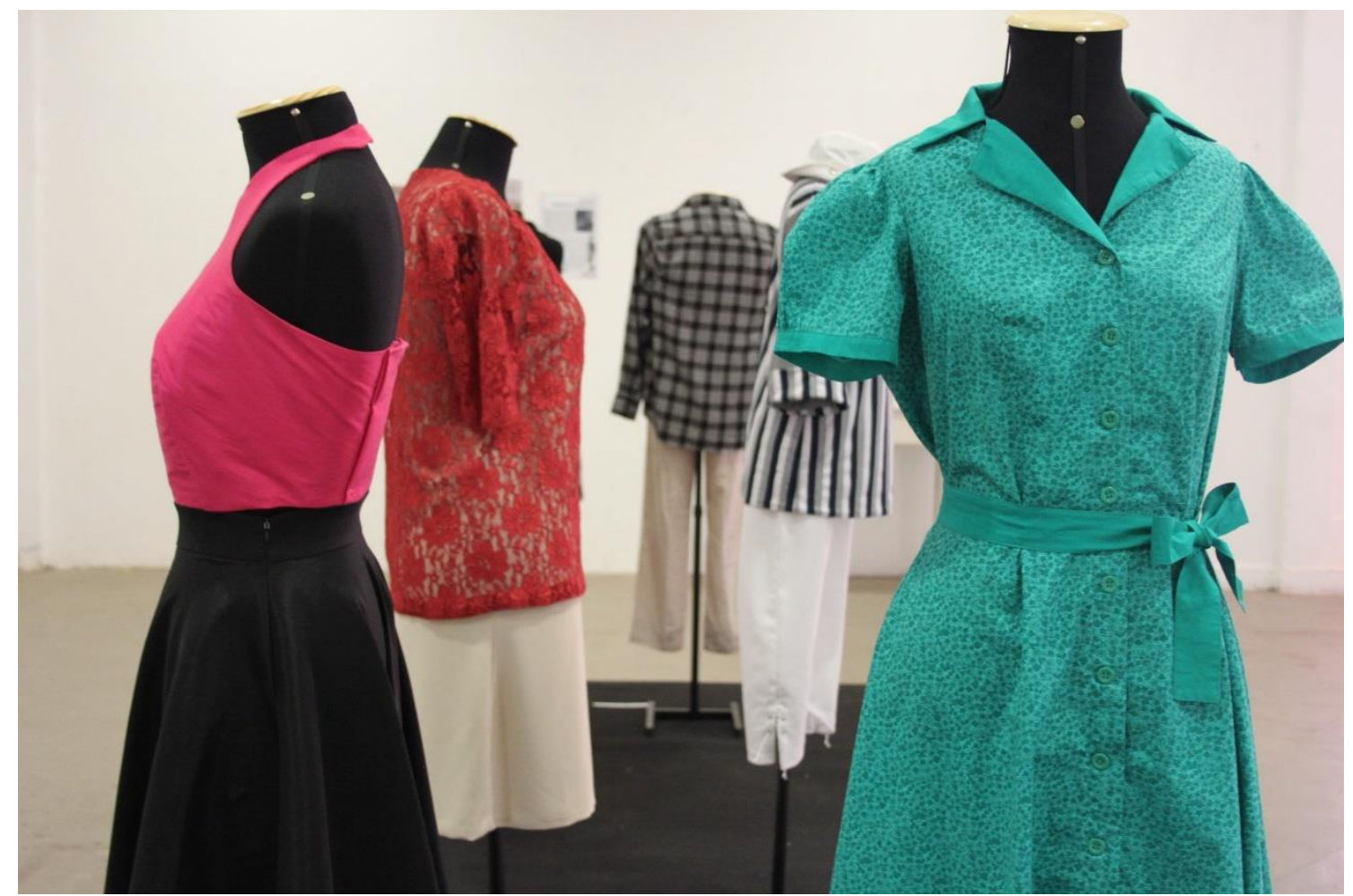

Foto: Aline Barbosa da Cruz Prudente, 2016.

\subsection{Como o projeto aconteceu}

Memórias Vestidas: Reconstrução de Indumentária aconteceu ao longo de nove meses. As oficinas e a exposição ocorreram no Museu da Imagem e Som da cidade de Campinas, São Paulo, com detalhado registro fotográfico, gráfico e audiovisual, publicado na forma de exposição e endereços virtuais ${ }^{55}$. A oficina oferecia vagas prioritariamente para a terceira idade, porém houve grande procura por jovens, oriundas ou não do projeto anterior. Tais presenças foram aceitas no curso e proporcionaram um encontro de gerações que enriqueceu o processo. Das onze participantes, seis tinham faixa etária acima

55 Disponível em: https://memoriasvestidas.tumblr.com/. Acesso em: 28 nov 2020. 
de 60 anos e cinco mulheres eram de faixas etárias diversas, dos 18 aos 50 anos (KUHL; PRUDENTE, 2016) ${ }^{56}$.

O processo do projeto contou com uma introdução sobre história da indumentária e exercícios de tradução de memórias em formas poéticas, onde as alunas receberam orientação de manter todo tipo de registros criativos: imagens, sentimentos, desenhos, ou seja, qualquer forma de expressão que emergisse do resgate de histórias e memórias relacionadas ao vestir. Essa primeira etapa (figura 22) contou com experimentos usando retalhos, exposição de memórias, que poderiam ser orais, ilustradas por imagens que as evocassem ou ainda com objetos e fotografias que tivessem feito parte dessas memórias

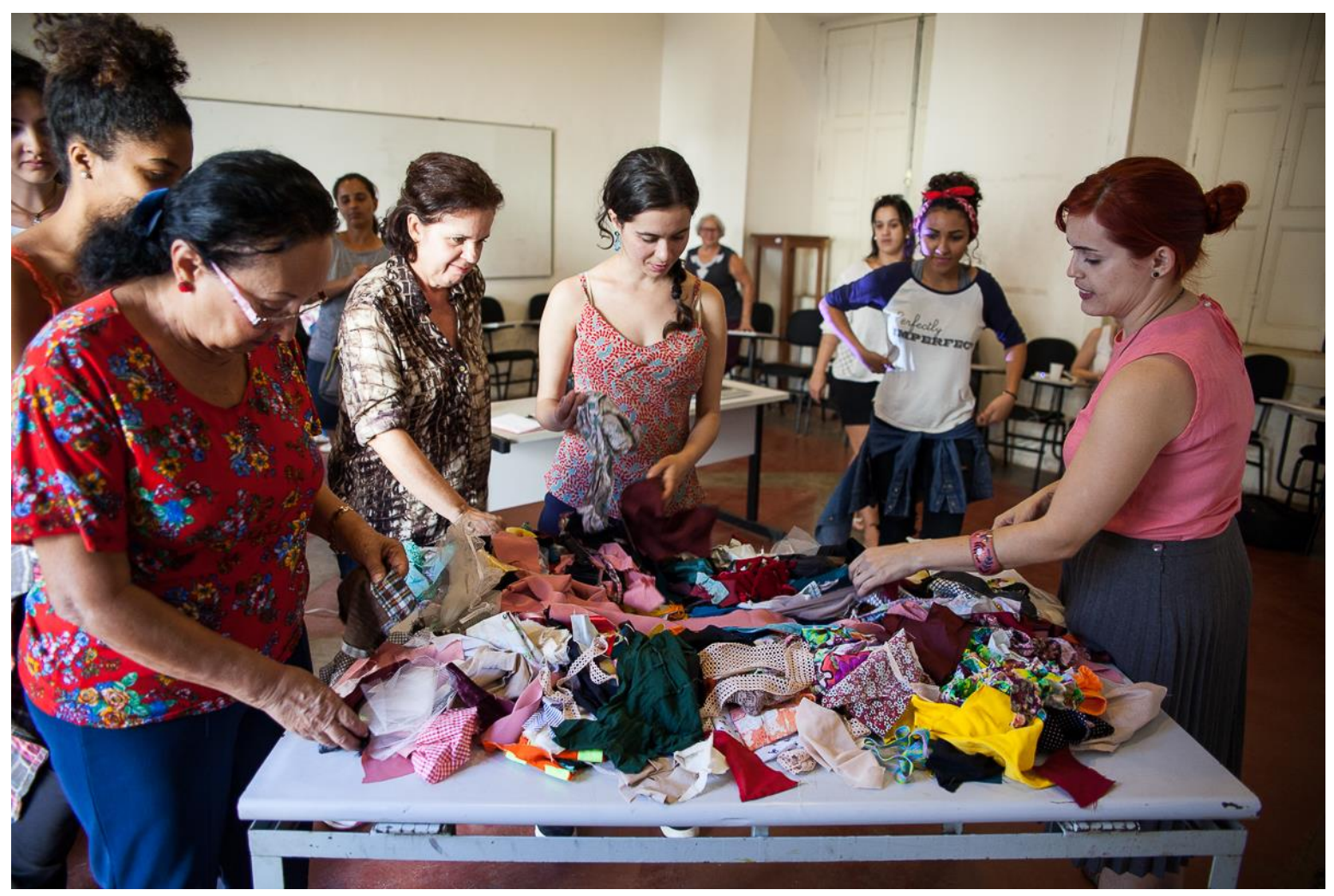

Figura 22 - Experimentos com retalhos durante aula do projeto

(figura 23).

Foto: Andrea de Lima, 2016.

56 Conforme relatado no artigo Memórias Vestidas: (re)criação de moda a partir da memória. KUHL, Anna Theresa; PRUDENTE, Aline Barbosa da Cruz. Revista de Moda Achiote. 2016. 
Figura 23 - Registros das memórias.

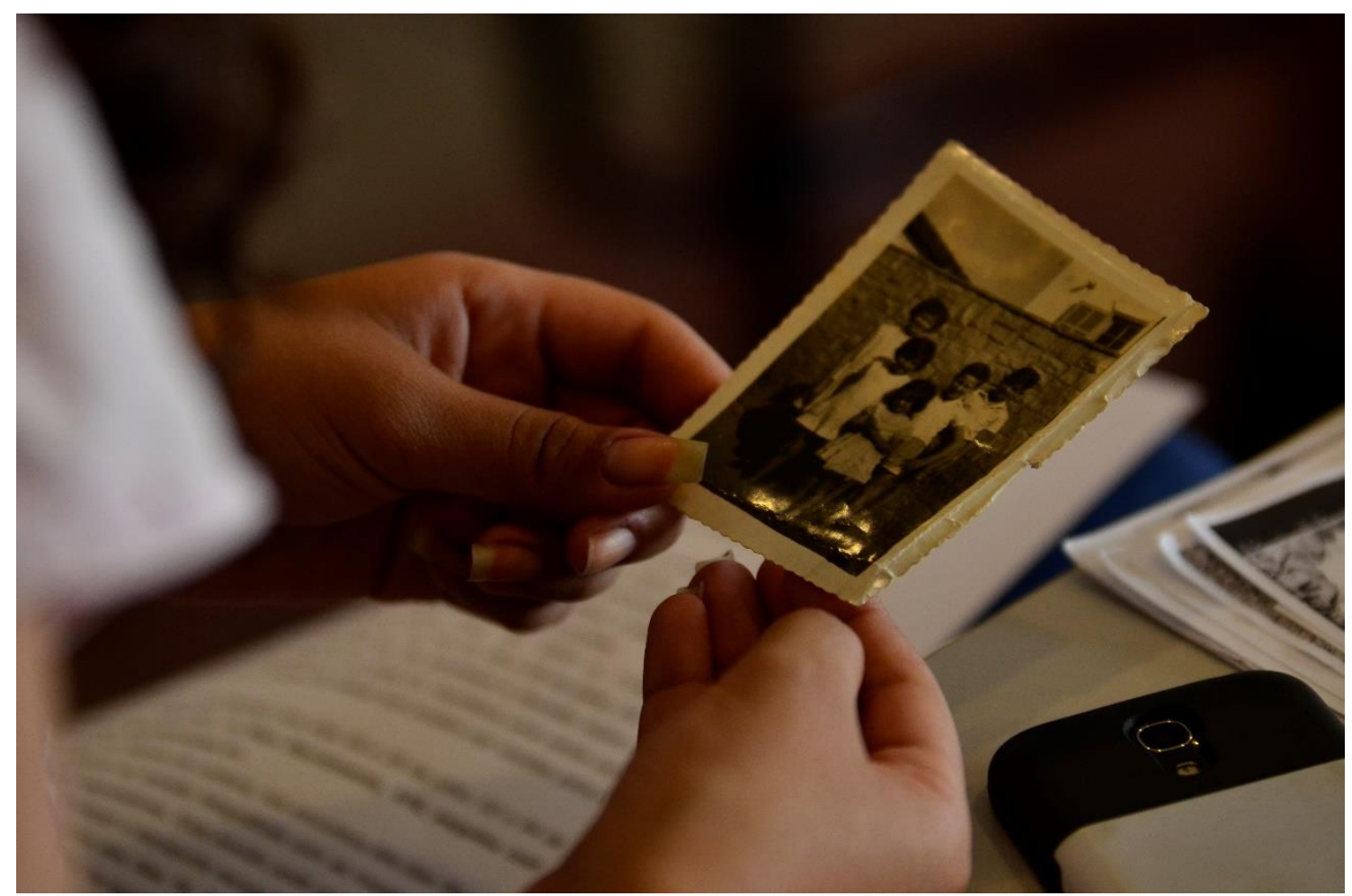

Foto: Maycon Soldan, 2016.

\subsection{Os objetos afetivos}

Além das fotografias, as participantes foram orientadas a trazer o que foi chamado na ocasião de objeto afetivo, elemento muito importante para materialização das memórias evocadas, caminho que possibilitou que memórias emergissem. Vestígios e marcas de tais lembranças foram então reelaborados como processo criativo. Tais objetos eram de naturezas diversas, como retalhos de tecido, livros, objetos religiosos ou de decoração, e se relacionavam com as memórias de indumentária que cada participante trazia.

Muitas vezes, como em uma das histórias que veremos mais a frente, existe um traço do documento (neste caso, o artefato livro), que evoca a memória de um vestido que será recriado. Ou no caso de outro livro, um catálogo de bordados da mãe de uma das participantes, que será relevante na criação de uma das peças do traje que será recriado por ela. O documento é peça 
importante no jogo entre imaginação e memória, ajuda a restaurar ou criar cronologias, que servirão às narrativas elaboradas.

Nesse sentido, o objeto traje pode evocar partes de narrativas, por meio das sensações que o material pode nos trazer. Para que haja memória, é relevante que o acontecimento não seja insignificante ao sujeito e se torne uma lembrança. No caso de Memórias Vestidas: Recriação de Indumentária observamos memórias de momentos cotidianos, mas que guardam relevância para o detentor daquele fragmento de tempo. Pessoalmente, para fins de exemplo de como essas memórias não precisavam vir de momentos extra cotidianos, tais como um casamento, a autora relembra a memória de uma blusa cinza canelada que emulava personagens imaginários durante a infância: amarrada na cintura ou quando as mangas cobriam os pulsos, esse traje emulava uma roupa de princesa. Algo que sempre foi feito pelas pessoas, a lembrança de um traje e suas conotações sensoriais, ganha sentido com as ações do projeto, dando corpo a ênfase de Peter Stallybrass (2012, p. 33) "as roupas são, pois, uma forma de memória".

\subsection{O processo de confecção e escolha das memórias}

$\mathrm{Na}$ etapa de confecção dos trajes, as participantes tiveram aulas de modelagem, a partir dos desenhos de seus projetos com Rosangela Rubbo. Cabe aqui um aparte sobre a professora, formada em Moda pela ESAMC, Campinas, onde apresentou como trabalho de conclusão o projeto Moda sem Grife (RUBBO, 2014), sobre o resgate da memória da moda no Brasil durante o século 20, que através de fotografias e depoimentos, tem como recorte:

[...] demonstrar como as pessoas comuns utilizavam as grandes tendências da moda. O ponto de partida é a análise de acervos fotográficos particulares que, juntamente com narrativas orais, contribuirão para observar a maneira com que a moda era adaptada e usada no cotidiano do brasileiro comum durante o século $X X^{57}$.

\footnotetext{
${ }^{57}$ Contato via acervo pessoal da autora, uma vez que o projeto de graduação não foi publicado.
} 
A presença de Rosangela foi fundamental e muito alinhada com a escolha das memórias escolhidas para criação dos trajes, uma vez que ela somou ao projeto não só conhecimentos técnicos de modelagem, mas um olhar muito sensível, característico de seu trabalho, para a questão da presença da indumentária na história pessoal feminina - é interessante notar que todas as participantes e as duas coordenadoras do projeto são mulheres.

Antes de ser iniciada a confecção, cada participante elaborou um croqui com detalhes de execução, a fim de orientar modelagem e acabamento. Essa etapa do processo também foi publicada na exposição, na forma de painéis que continham o depoimento da memória e os documentos da etapa de planejamento do traje, como se vê na figura 24.

Figura 24 - Painel exposto junto aos trajes.

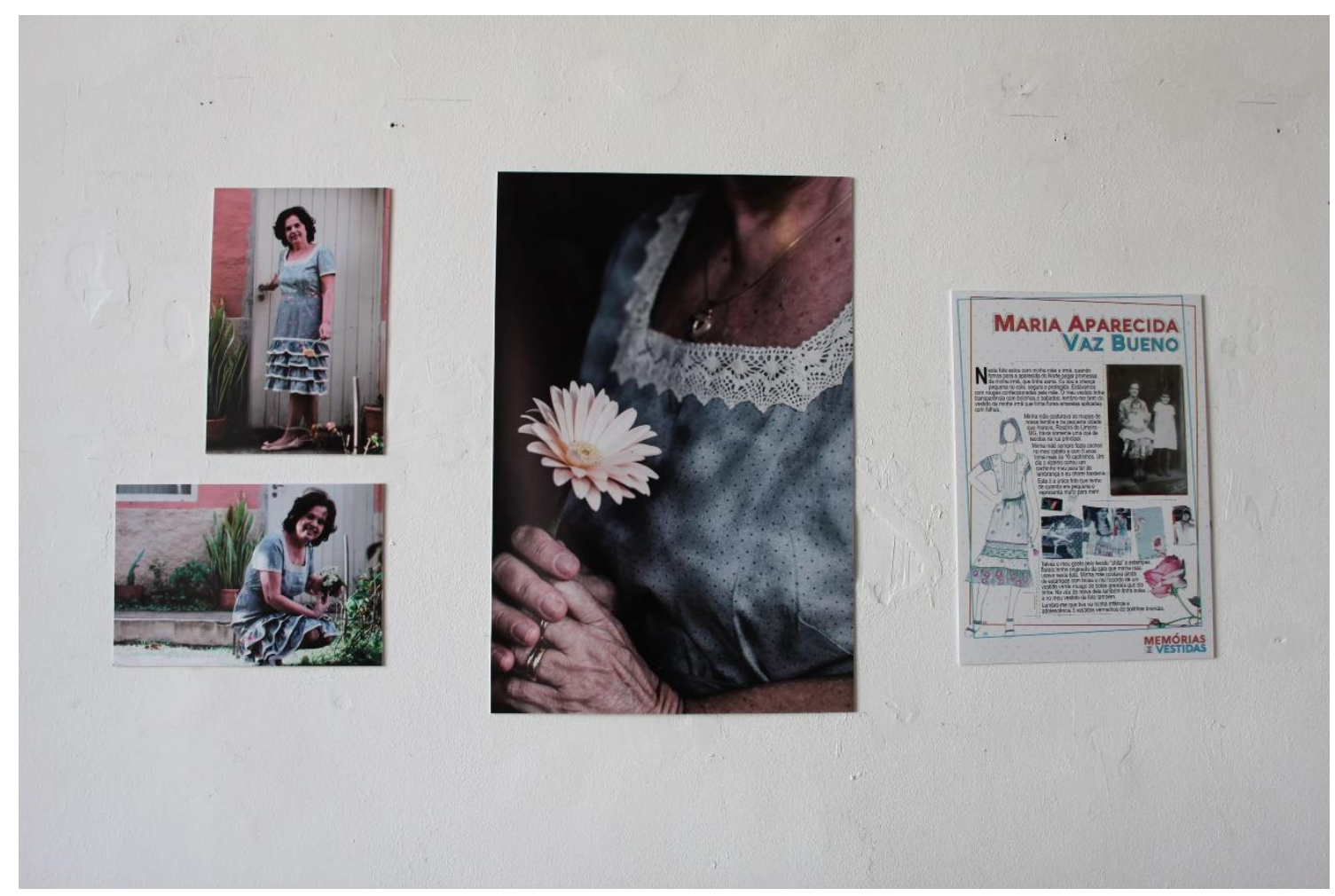

Foto: Aline Barbosa da Cruz Prudente, 2016.

Como escolher entre essas memórias emolduradas que são trazidas pelas participantes? "Uma lembrança é diamante bruto que precisa ser lapidado pelo espírito" (BOSI, 1994, p. 39). Era natural que eventos significativos, tais 
como um casamento, aparecessem como pedidos de recriação de algum traje. E não deu outra: uma das primeiras propostas foi um vestido de noiva (figura 25) de uma das participantes, o que seria inviável em questão de tempo e recursos.

Figura 25 - O vestido de noiva de Maria.

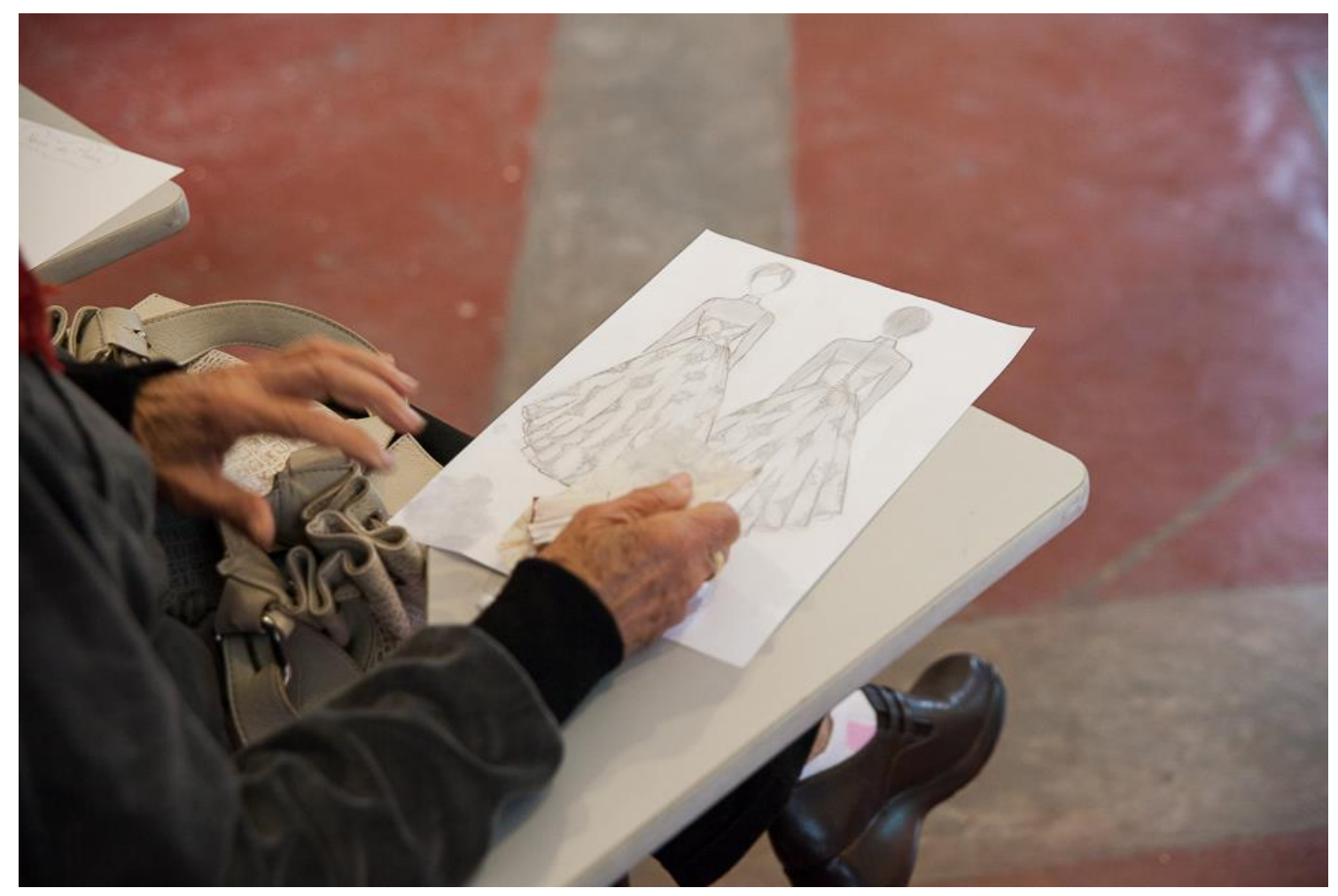

Foto: Andrea de Lima, 2016.

Rosângela faz então uma sugestão certeira: por que não refazer o vestido que a participante usava quando conheceu o marido? Essa sugestão vai trazer outra abordagem para aquela memória, fazendo emergir um caráter de celebração dos anos da participante junto ao marido, que abordaremos mais tarde.

Nessa etapa, foram realizadas compras de materiais (de segunda mão e a maior parte em lojas de tecidos e aviamentos) e aulas de modelagem, onde os trajes foram confeccionados, e as participantes com mais experiência auxiliavam as que não tinham habilidade com a costura. Menos que nos projetos anteriores, nesse contexto também acontece uso de resíduos e peças de segunda mão, como um bolero feito de cortina ou ainda um casaco de segunda mão que é 
reestruturado para uma das memórias, como veremos caso a caso, nos textos a seguir.

\subsection{As figuras familiares}

Muitas figuras parentais, principalmente mães, avós e avôs foram evocados nas memórias trazidas pelas participantes. Uma delas, Teresa, trouxe um objeto afetivo que seria fundamental para a escolha de seu traje recriado: 0 caderno de bordados (Figura 26), que havia sido de sua mãe, quem confeccionou para ela na infância um vestido com delicado bordado de pérolas, memória matriz escolhida para a criação da participante. 
Figura 26 - Página do caderno de bordado

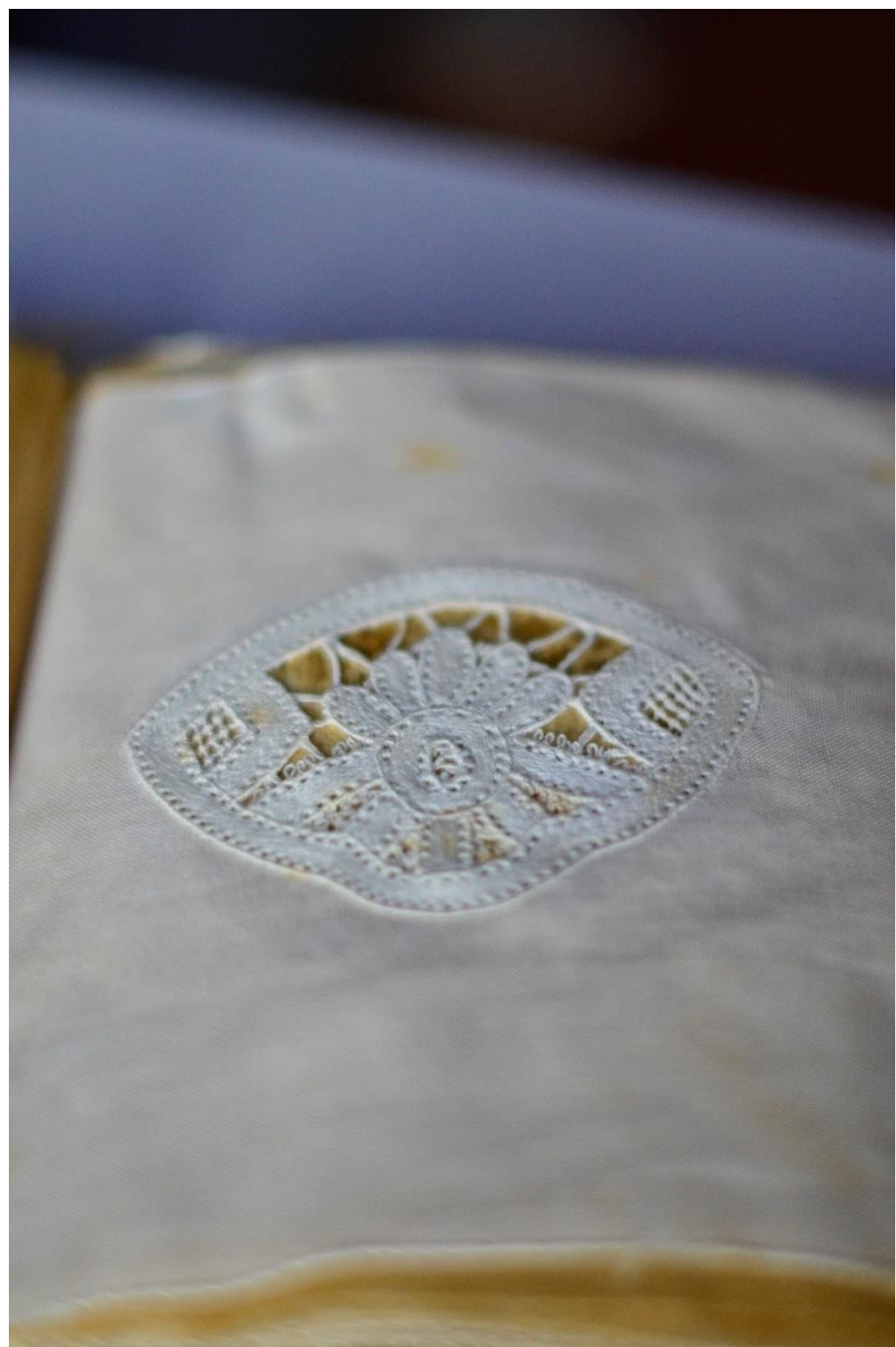

Fotógrafo: Maycon Soldan

O bordado do caderno influenciou o traje de Teresa, que confeccionou um bolero (figura 27), feito de resíduo têxtil, no caso, uma cortina, com uma trama que a fazia lembrar do caderno. 
Figura 27 - O bolero confeccionado por Teresa

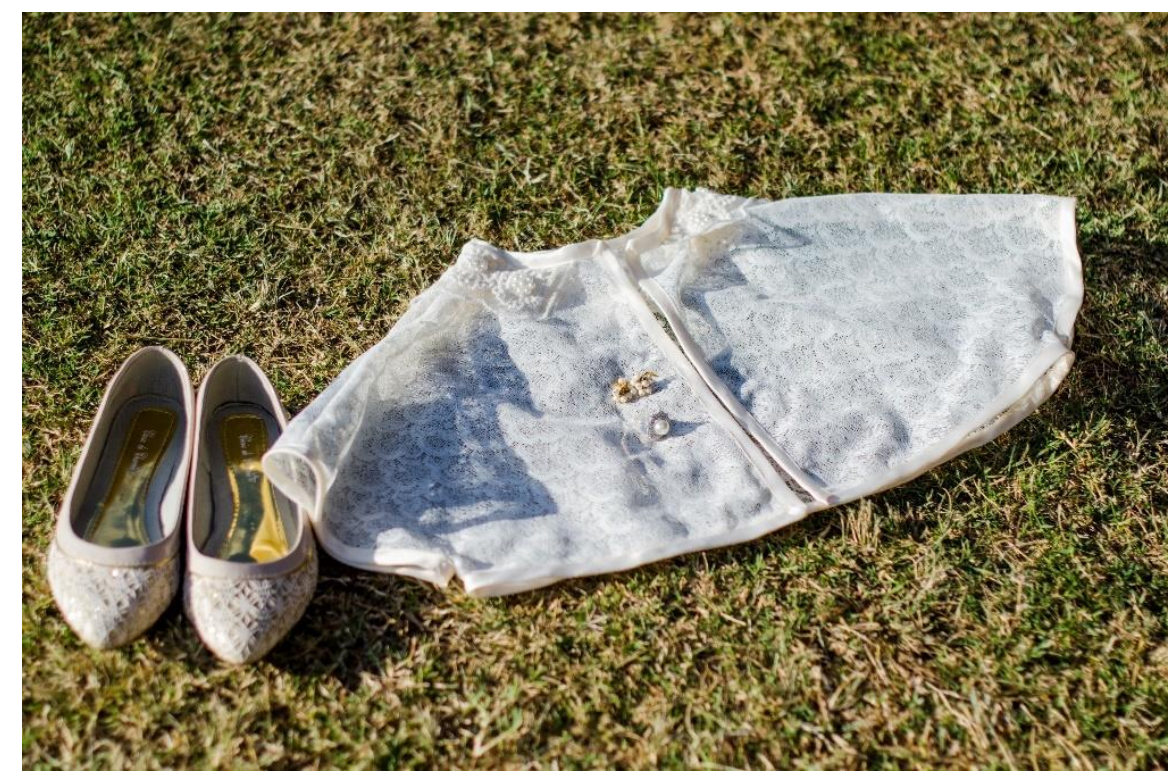

Foto: Maycon Soldan, 2016

Outra participante, Maria Aparecida, trouxe diversos objetos que haviam pertencido a sua mãe, falecida recentemente. Essa era uma memória que sempre a emocionava, e junto ao traje exposto e desfilado, organizou quase que um pequeno altar de objetos (figura 28) para homenagear sua mãe, inclusive onde figuram uma pequena toalhinha com bordas de crochê e um quadrado de patchwork. 
Figura 28 - Objetos durante exposição

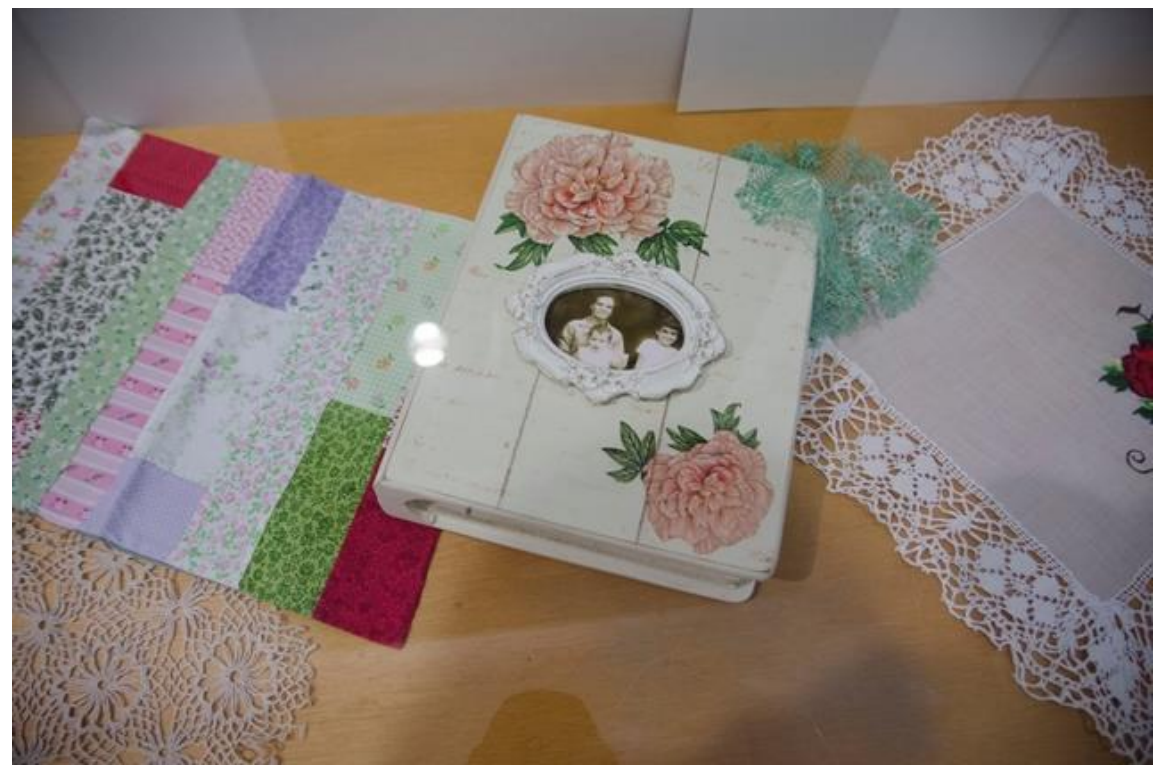

Foto: Maycon Soldan, 2016

Por sua vez, a jovem Roberta também escolheu homenagear figuras maternas. Em seu depoimento a Kühl e Prudente (2016), o qual integra a exposição, ela diz:

Quero contar que eu e minha mãe somos muito unidas. Um dia, olhando as fotos antigas de minha mãe quando jovem, pensei como era interessante o quanto as mulheres se vestiam de maneira comportada, com vestidos até o joelho e manga também... ${ }^{58}$

A questão das mangas repercute no traje final, uma vez que Roberta é evangélica e não tem costume de usar os ombros à mostra. Ela não havia tido tempo suficiente para modelar mangas ao seu vestido, por isso, a equipe e demais alunas se mobilizaram para que um bolero fosse garimpado e ela pudesse participar da sessão de fotos com os ombros cobertos (figura 29).

58 Disponível em: https://memoriasvestidas.tumblr.com/post/160033267745. Acesso em 30 mar. 2021. 
Figura 29 - O traje com bolero

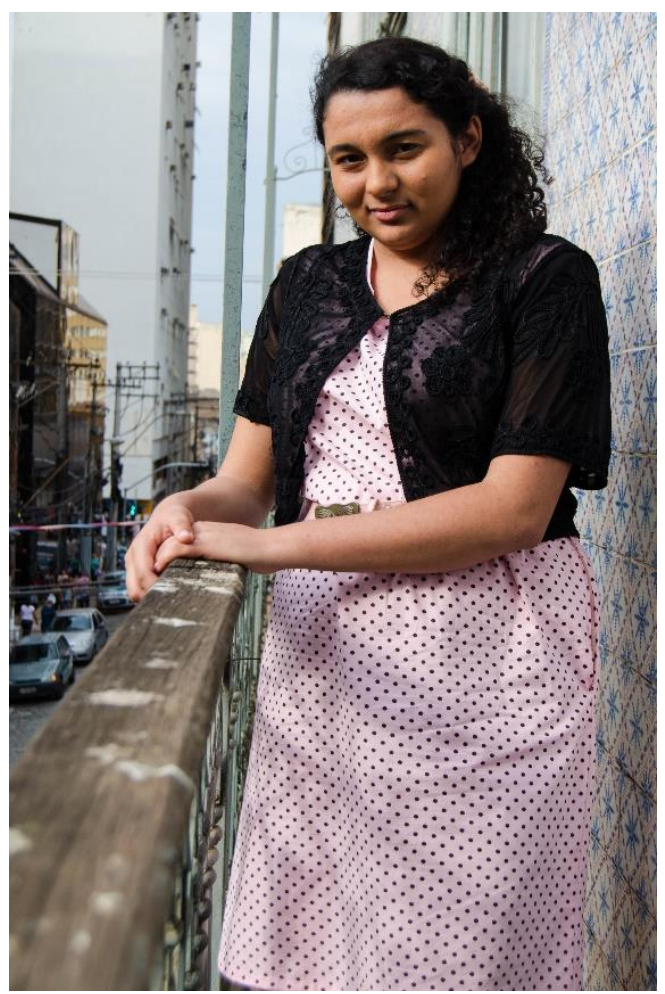

Foto: Maycon Soldan, 2016

Roberta não compareceu ao desfile final. Embora não configure um traje que tenha sido usado para frequentar igrejas, a jovem era muito religiosa, e é interessante notar que existe um termo para a indumentária de certas religiões no Brasil, neste caso específico, a chamada moda modesta, que pode ser definida conforme depoimento da própria Roberta dado a Kühl e Prudente (2016): "continuamos a usar vestidos assim até hoje - saia rodada, manguinha, saia até o joelho, cinto na cintura".

Ainda sobre figuras da família, a participante Letícia vai trazer seu avô e sua avó, recriando dois trajes, um do gênero feminino e outro masculino (figura 30). A padronagem xadrez e a textura da flanela se repetem tanto na camisa do avô quanto na saia da avó. A saia foi costurada por Letícia, e as demais peças, garimpadas e arranjadas dentro do cenário das memórias dela. 
Figura 30 - Memórias do avô e da avó

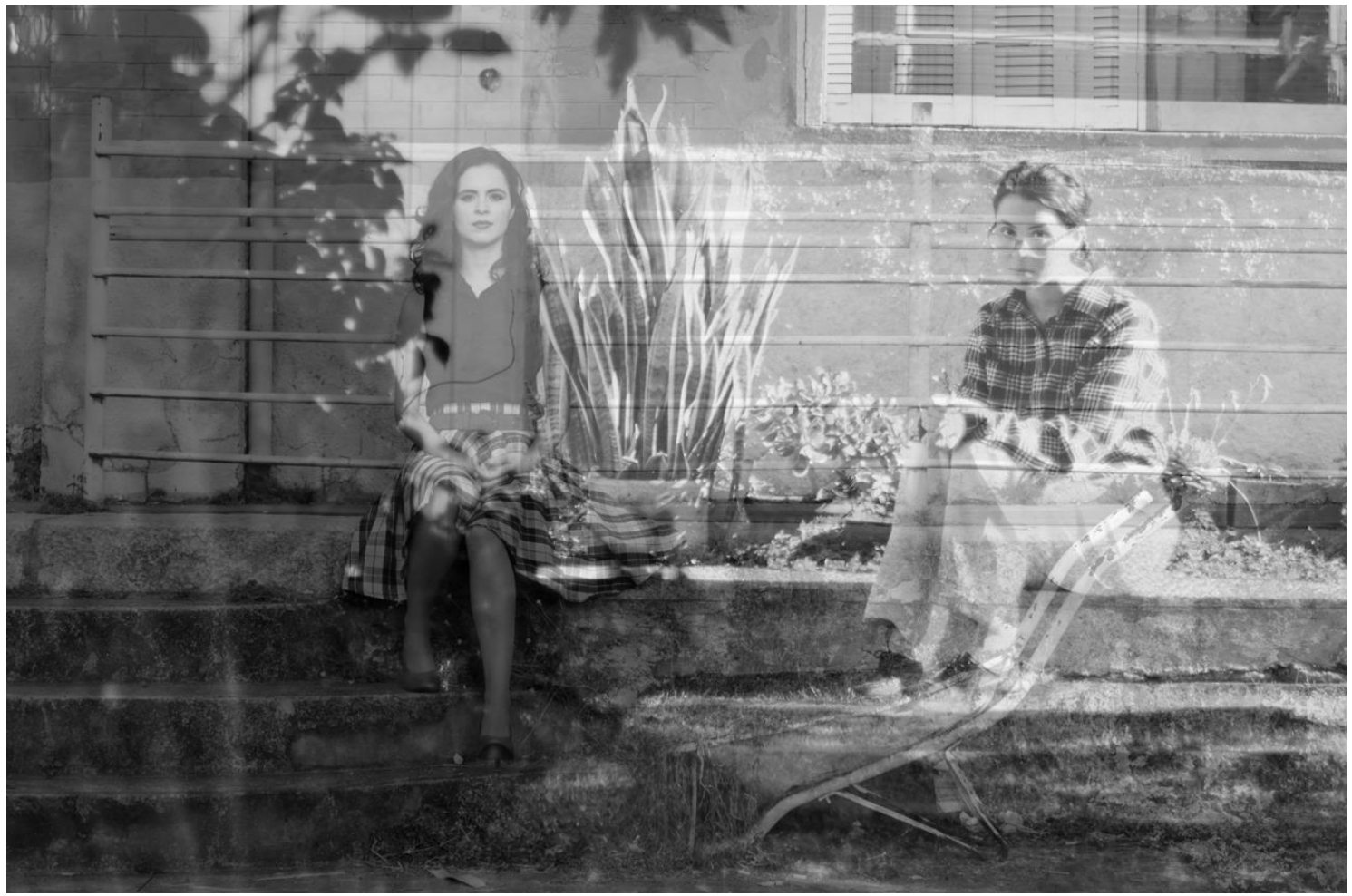

Foto: Maycon Soldan, 2016.

A participante Lígia escolheu uma memória de um familiar que ela não havia conhecido, cuja foto datava da década de 1940. Filomena, tia avó de seu avô, "vestia-se de uma maneira formal, séria e sóbria" (Idem) e teve uma trajetória feminista em um ambiente e uma época extremamente machistas; criou os filhos, sustentou a casa, cuidou do marido, e principalmente "cresceu em liberdade com seu espírito" (Ibidem). Segundo Lígia, sua história de vida foi tão incrível e complexa que parecia ter saído de uma narrativa ficcional. Ela então recria o traje dessa memória (figura 31), usando materiais de segunda mão, como um casaco encontrado no bazar, além de peças confeccionadas durante a oficina (figura 32). 
Figura 31 - Filomena, memória escolhida pela participante

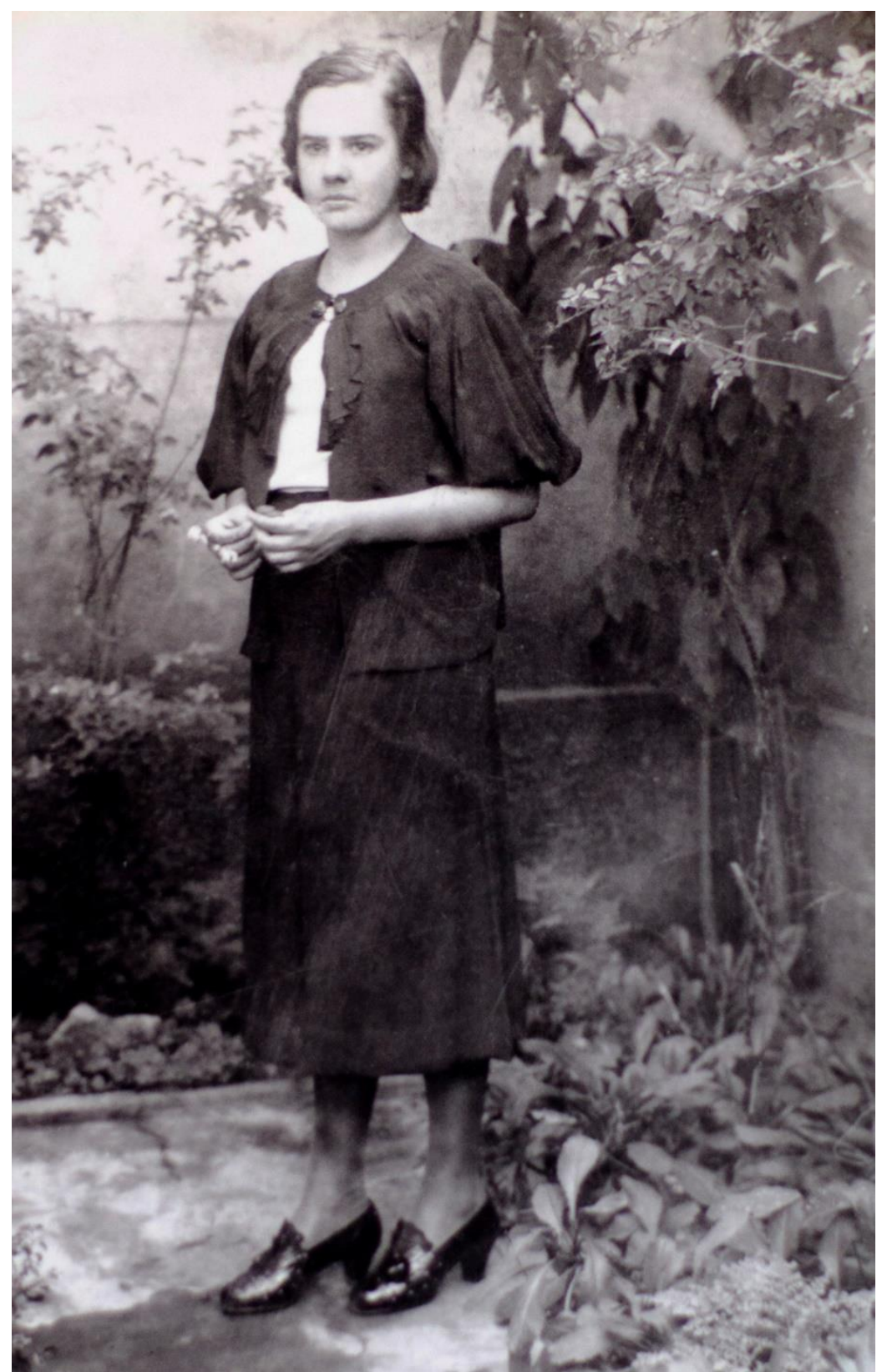

Foto: Acervo pessoal da participante, sem data específica. 
Figura 32 - O traje da participante

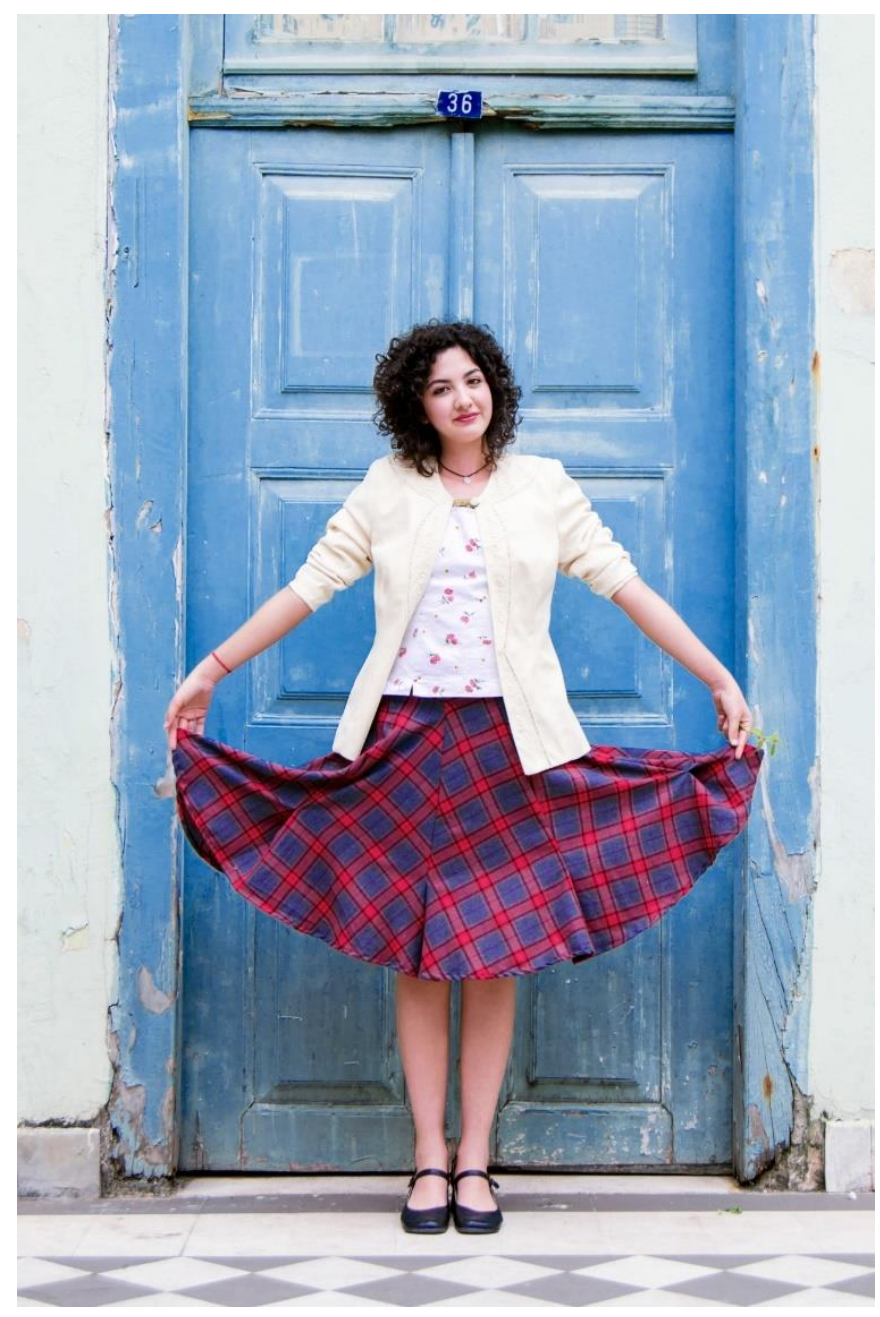

Foto: Maycon Soldan, 2016.

\subsection{Marlene e a impecabilidade}

Profissional de costura, reformas e ajustes durante mais de três décadas, Marlene trazia de maneira muito potente a questão da manufatura têxtil, elemento de sua trajetória profissional e história familiar. A participante fez uma criação que mesclou elementos masculinos - o casaco, presente nas memórias (figura 33) sobre seu pai e irmãos, e elementos femininos, evocando a memória da mãe e o ofício da costura. O casaco é de linho, encontrado em um bazar de 
peças de segunda mão, já o vestido foi confeccionado pela participante. Em seu depoimento ${ }^{59}$, ela aponta:

Fui criada com muito capricho por meus pais, meu pai foi lavrador, muito trabalhador, dizem que sou parecida com ele, em relação ao aspecto físico e às atitudes também. Já minha mãe era dona de casa, mãe de seis meninas e dois homens, e embora muito simples, nos criou com as melhores maneiras, com muita graça e feminilidade. Os dois nos vestiam de maneira muito caprichada, faziam questão de estarmos sempre bem vestidos. As roupas eram feitas de sacos de açúcar, que eram arejados, branqueados e às vezes até bordados. Tudo tinha muitos detalhes - babado, bordado, cinto, mangas bufantes. Tenho muita saudade desse tempo, do calor da nossa família. Por isso, fiz um vestido que me lembra esta época, e o blazer me faz lembrar do meu pai e meus irmãos.

Figura 33 - Memórias de família

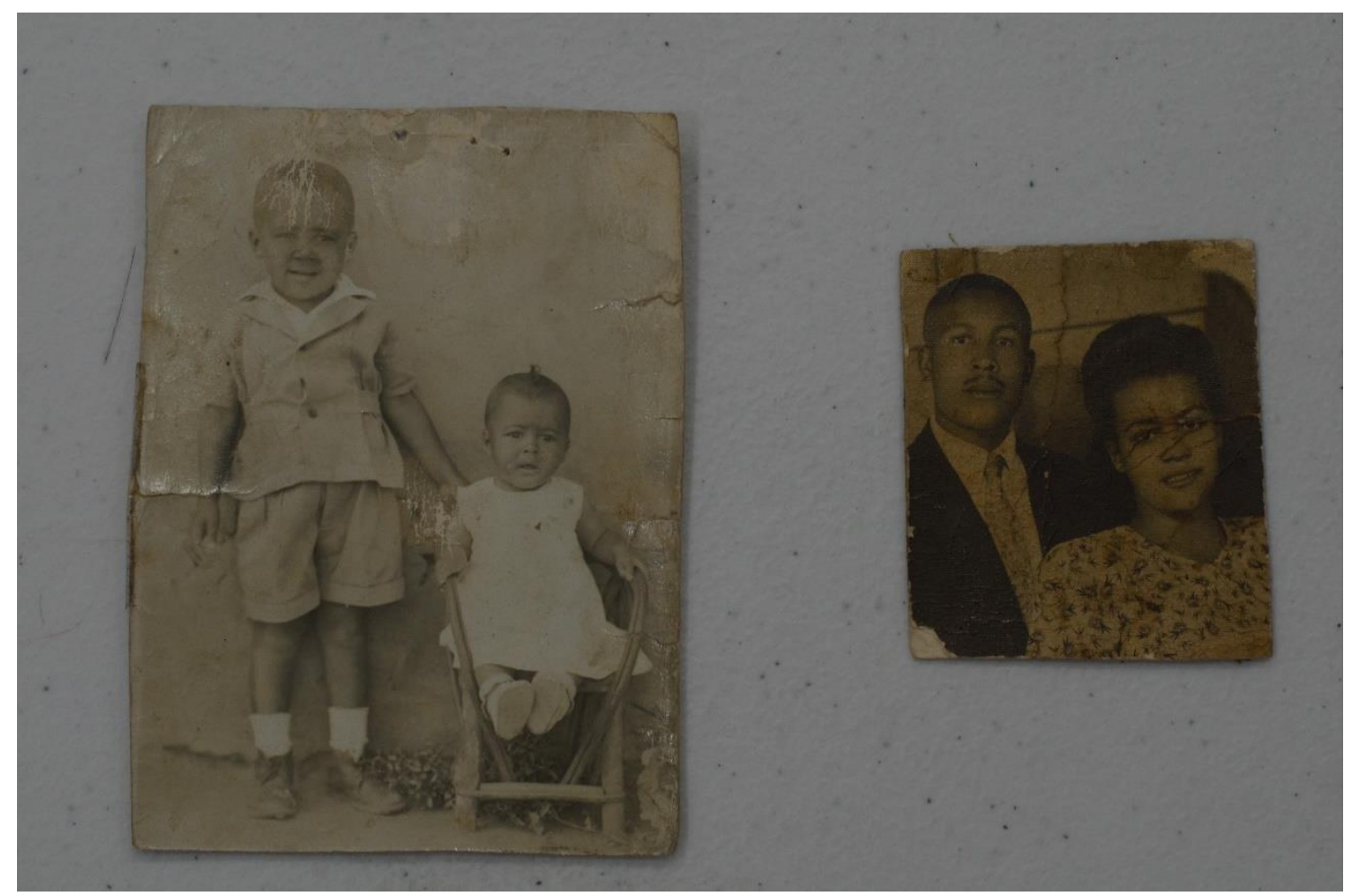

Foto: Maycon Soldan, 2016.

59 Disponível em: https://memoriasvestidas.tumblr.com/post/160033186345. Acesso em $04 \mathrm{dez}$. 2020. 
Muitas foram as inquietações cultivadas durante o curso Histórias do vestir: cinco artistas negros no acervo do MASP ${ }^{60} \mathrm{com}$ a pesquisadora Hanayrá Negreiros, em 2020. Historicamente, foi exposta uma questão de como o vestir vai engajar pessoas negras, seja porque a mulher negra teve durante muito tempo responsabilidades ligadas a cuidar dos trajes, sendo aquelas que costuram, lavam, passam; seja pela questão da segurança que a impecabilidade pode imprimir ao homem negro, que precisa estar bem-vestido em toda ocasião. Esse engajamento é muito presente e potente tanto nas memórias, quanto no traje criado por Marlene (figura 34). Outro detalhe importante nessas histórias do vestir apresentadas no curso, também muito relevante para nossa participante, eram os sapatos, que deveriam estar impecáveis, sempre.

Figura 34 - Traje da participante

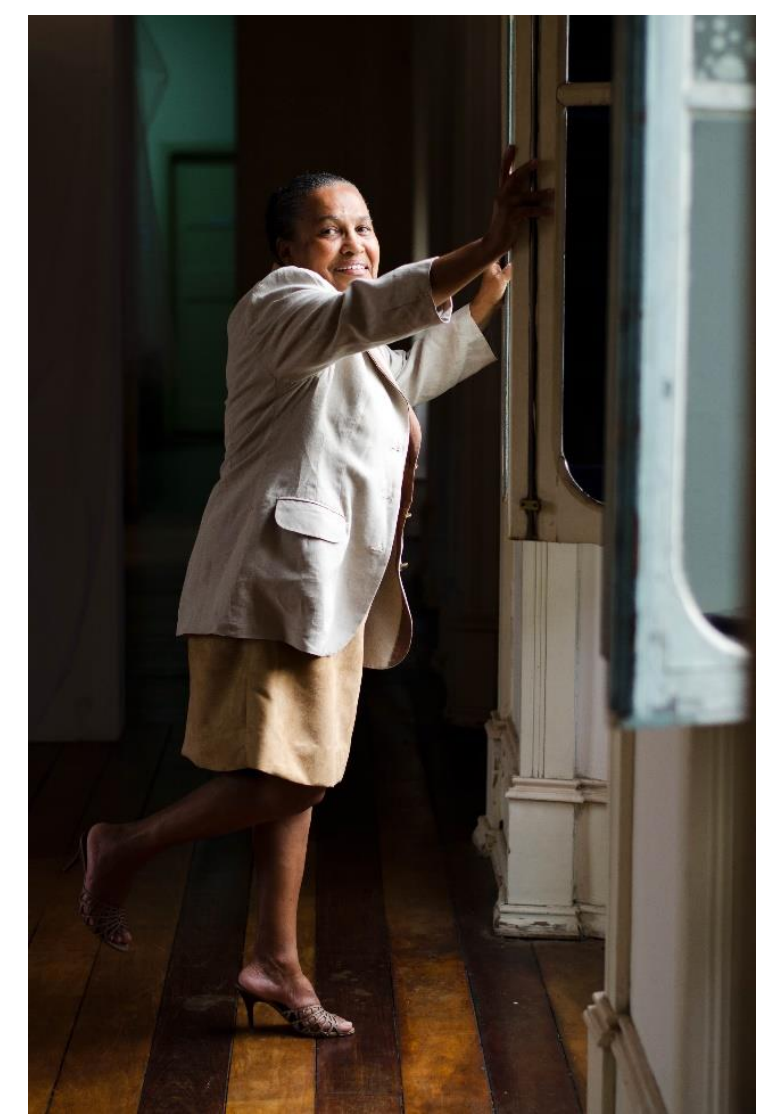

Foto: Maycon Soldan, 2016.

${ }^{60}$ Curso oferecido de maneira virtual durante os meses de julho e agosto de 2020. 
O ponto de convergência entre as histórias que Negreiros (2020) apresenta durante o curso no MASP e a participação de Marlene no projeto foi justamente a costura.

A habilidade profissional da confecção, uma "relação estreita entre memória e trabalho" (BOSI, 1994, P. 397) também esteve presente na história de demais participantes do projeto, todas elas mulheres. A manufatura do traje sempre se fazia presente, de alguma maneira, nas memórias selecionadas.

\subsection{Pontos de contato entre o projeto e processos de criação de}

\section{figurino}

Embora o objetivo final do projeto Memórias Vestidas: Reconstrução Poética de Indumentária não fosse a criação de trajes de cena, as autoras do projeto, ambas figurinistas, puderam identificar processos similares. Assim como em um processo de traje de cena, as participantes tiveram a oportunidade de passar por etapas que também vão acontecer no processo de criação de um traje de cena, como pesquisar e buscar materiais têxteis diversos de segunda mão que se encaixassem em seus projetos, em acervos pessoais ou durante visitas a bazares. Foram encontradas algumas peças, que poderiam fazer parte do traje em si ou da ambientação da exposição. Em seguida, foram buscados tecidos e aviamentos a partir dos croquis de cada aluna. Um processo muito similar aos de produção de figurino vivenciados pela autora desta pesquisa, que atua como figurinista no contexto das artes cênicas no interior paulista desde $2007^{61}$. Nestes processos, também se cria a partir de material existente como exercício, para depois somar camadas de significado. No caso do processo vivido no projeto Memórias Vestidas: Reconstrução de Indumentária, a primeira camada foi a memória em si; a segunda, o (re)desenho a partir das referências, e em alguns casos, a ressignificação de objetos/trajes de segunda mão, para que então viesse a confecção e acabamento.

O processo mais similar ao de produção de um traje de cena foi executado por Rose Marie, participante que contava com experiência, repertório e formação

\footnotetext{
61 Experiências detalhadas em seu site pessoal, disponível em www.annakuhl.com, acesso em
} 10 de setembro de 2020. 
em moda, além de exímia costureira. Ela apresentou dois trajes (figura 35) a partir da memória de uma época que ela não viveu, mas que admira muito, a década de 1920: um traje social para ela própria, e outro de banho para a participante Lígia, cuja aparência fazia lembrar a de atrizes do cinema dessa década.

Figura 35 - Trajes de uma época não vivida

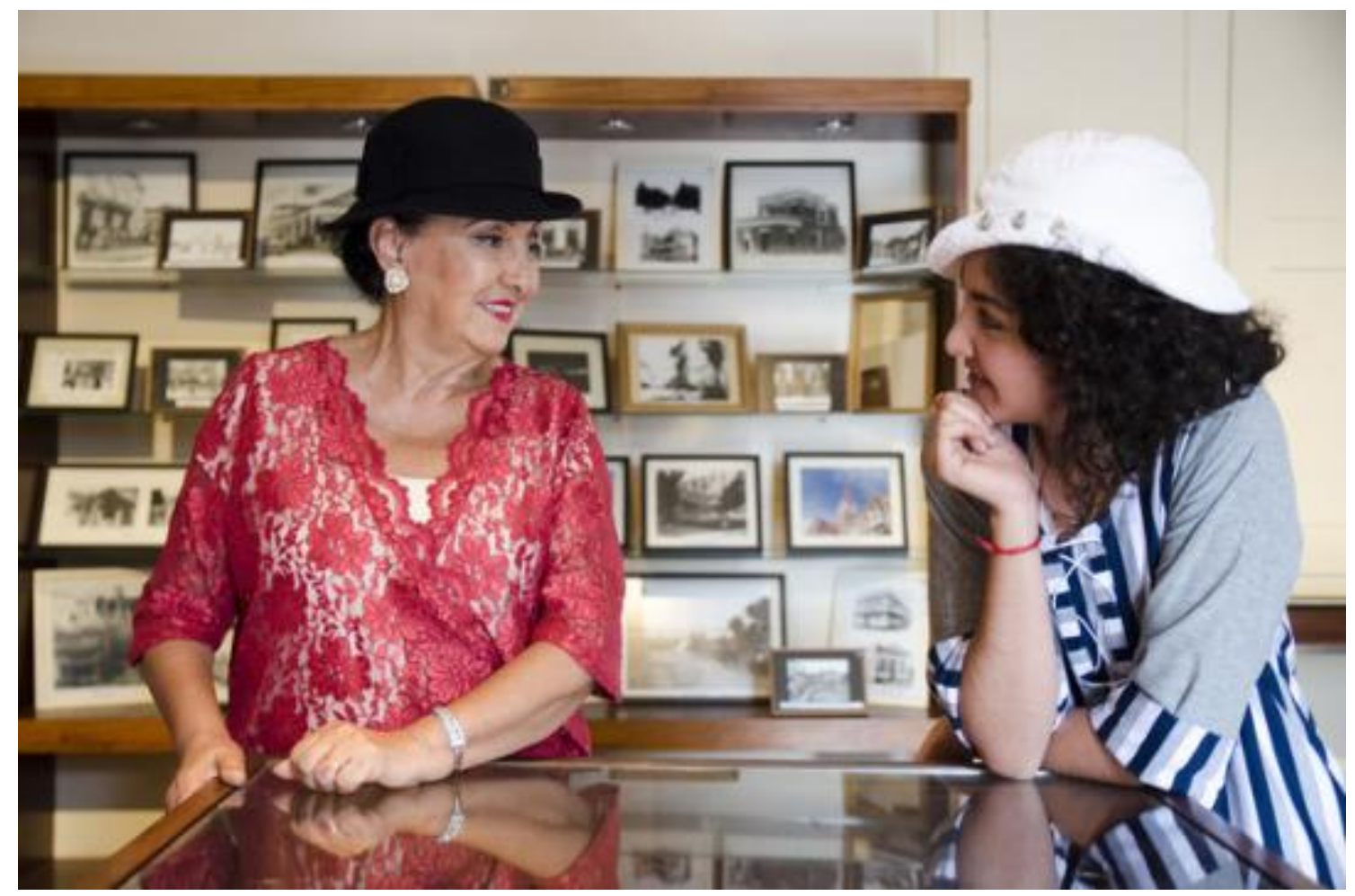

Foto: Maycon Soldan, 2016.

\subsection{Memórias da infância}

O olhar para o passado não se voltou apenas para homenagens a tempos mais distantes. Duas participantes olharam para suas infâncias, trazendo memórias desses tempos. Existe um carinho por essa etapa da vida, mesmo com seus percalços “(...) a criança sofre, o adolescente sofre. De onde nos vêm, então, a saudade e a ternura pelos anos juvenis?" pergunta BOSI (1994, p.41).

Uma das histórias relatadas no projeto é sobre uma peça que não sobreviveu como objeto, mas como lembrança. A participante Helenice, em seu 
depoimento, conta sobre "O vestido que desbotou, mas que não saiu da memória"62:

Quando me perguntaram se eu me lembrava de "algum vestido que marcou sua vida", minha memória foi buscar imediatamente o vestido desbotado que minha avó fez para mim. Minha família naquela época era muito pobre. Vestíamos roupas doadas dos outros e raramente podíamos comprar roupas novas. Certa vez nos meados dos meus cinco anos, minha avó me deu um corte de tecido todo floridinho, e achei aquele tecido a coisa mais linda do mundo. Ele era cheio de florzinhas coloridas com muitas folhas verdes iguais a um jardim. Fiquei tão feliz, mas tão feliz que não via a hora de ver meu vestido florido. Minha avó não tinha máquina de costura, portanto tinha que costurar à mão. Bem, pega hora, pega amanhã para costurar, o tecido foi sujando e quando ficou pronto, precisou lavar antes de usar, aí a desgraça... o vestido desbotou e as florzinhas sumiram todas. Eu chorei muito e não queria vestir aquele vestido que ficou branco de jeito nenhum. Minha mãe conversou muito comigo para me convencer a por o vestido e não deixar minha avó triste. Agora que estou participando do projeto resolvi recriar o vestido desbotado que não saiu da memória. Estou usando tecido estampadinho, meio parecido com o da minha infância, usando o lado direito e o avesso para relembrar minha história. (Kühl e Prudente, 2016) ${ }^{63}$

Helenice propôs uma releitura que celebra os dois momentos do vestido em sua memória, tanto a estampa viva, quanto desbotada. Seu relato e o traje confeccionado (figura 36) celebram a efemeridade do objeto material e a permanência em sua memória.

62 Disponível em: https://memoriasvestidas.tumblr.com/post/160031622035. Acesso em 04 dez. 2020.

63 Disponível em https://memoriasvestidas.tumblr.com/post/160031622035. Acesso em 04 dez 2020. 
Figura 36 - Avesso e desbotamento

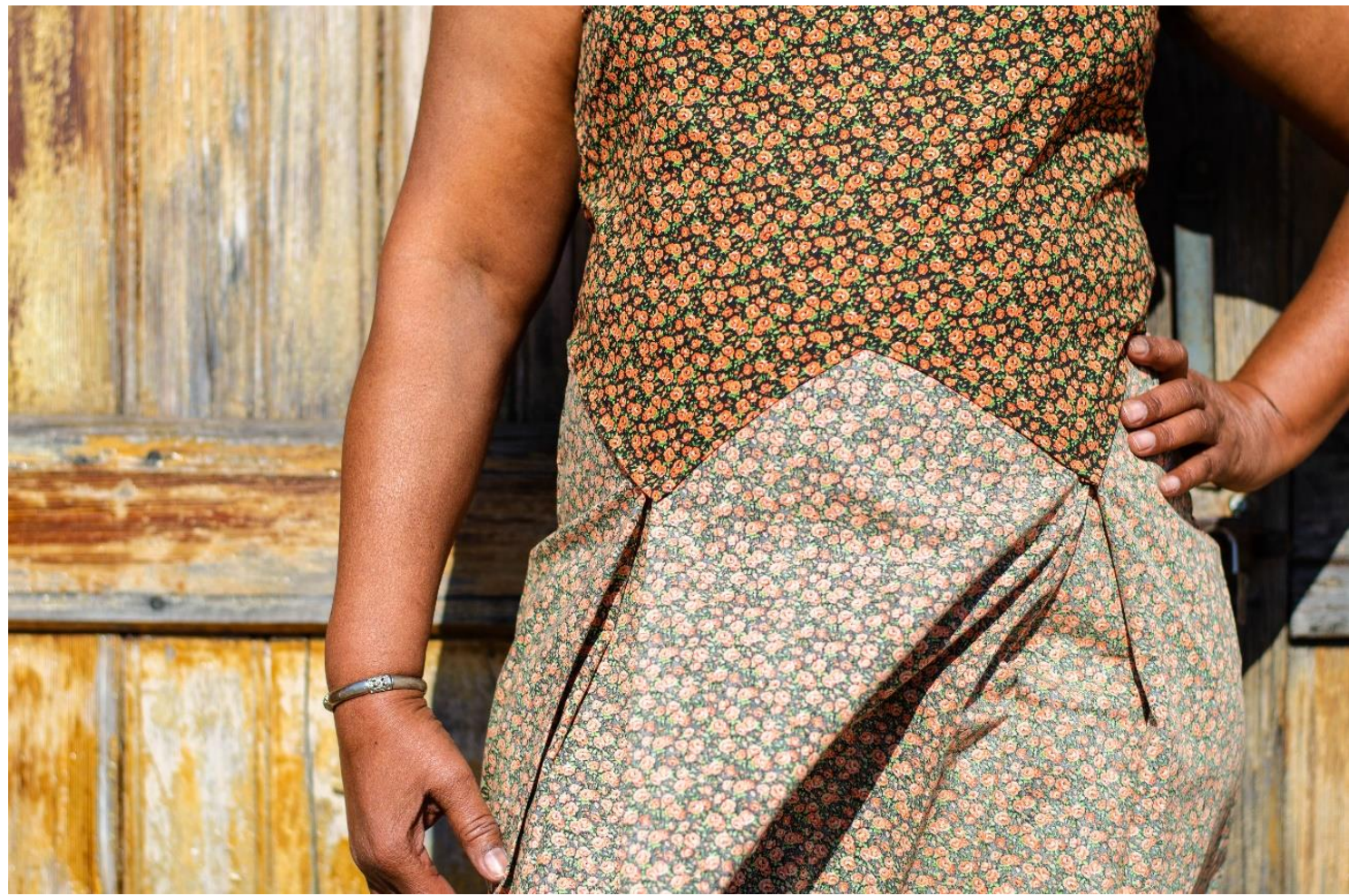

Foto: Maycon Soldan, 2016.

Outro traje que relembra a infância foi a criação de lara, a partir de uma blusa de criança, que serviu por diversas idades diferentes (figura 37), ou nas palavras dela:

Buscando memórias em fotos encontrei três fotos que me registraram em anos e momentos completamente distintos da minha vida, com uma mesma blusinha rosa, quase como se a blusa tivesse crescido comigo. Foi desse apego por uma roupa da minha infância que comecei a trabalhar atrás dessa memória tão divertida para criar a minha indumentária, juntando com a memória de saias bem rodadas que são uma homenagem às memórias de minha vó. (idem) ${ }^{64}$

64 Disponível em: https://memoriasvestidas.tumblr.com/post/160032495385. Acesso em 04 dez. 2020. 
Figura 37 - Fotos de infância

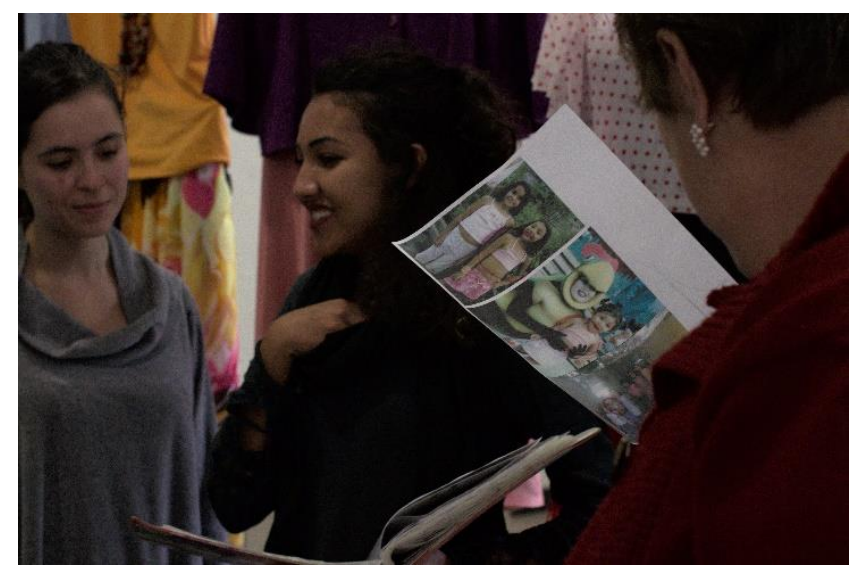

Foto: Maycon Soldan, 2016.

Esses dois trabalhos ilustram como pode se organizar a memória do jovem ao longo da série cronológica "que cada um de nós organiza quando reconstrói os fatos da própria vida" (BOSI, 1994, p. 18). Mesmo com memórias amargas, perduram as lembranças doces, que reelaboramos e não esquecemos.

\subsection{Celebração do traje como potência de vida}

Embora olhar para o passado possa fazer emergir lembranças dolorosas, ressignificar estes momentos podem nos trazer elaborações importantes, como as que vimos durante a execução do projeto. $O$ traje não apenas relembra, mas também oferece oportunidades de exercer o lúdico, viver o não vivido, como no depoimento de Rose Marie. Ou ainda, principalmente, no depoimento de Maria, que no princípio, incentivada pela neta lara, também participante do projeto, queria refazer seu vestido de noiva, mas não só, queria celebrar sua vida com o marido. Por isso refazer o traje com o qual ela havia conhecido aquele homem poderia ser não apenas mais viável, mas tão simbólico quanto. Segundo seu depoimento:

Este vestido é de quando conheci meu querido marido há 58 anos atrás. No dia em que eu estava pela Vila Brasilândia, quando passei na frente da casa dele, eu estava com um livro na mão, um hinário. 
Joguei pra cima dizendo: "Wenceslau, você é meu". (Kühl e Prudente, $2016)^{65}$

O próprio objeto afetivo que ela traz conta essa história - é justamente o hinário que ela joga para cima, como vimos no depoimento, e que ela aparece segurando na figura 38 :

Figura 38 - Traje e objeto afetivo.

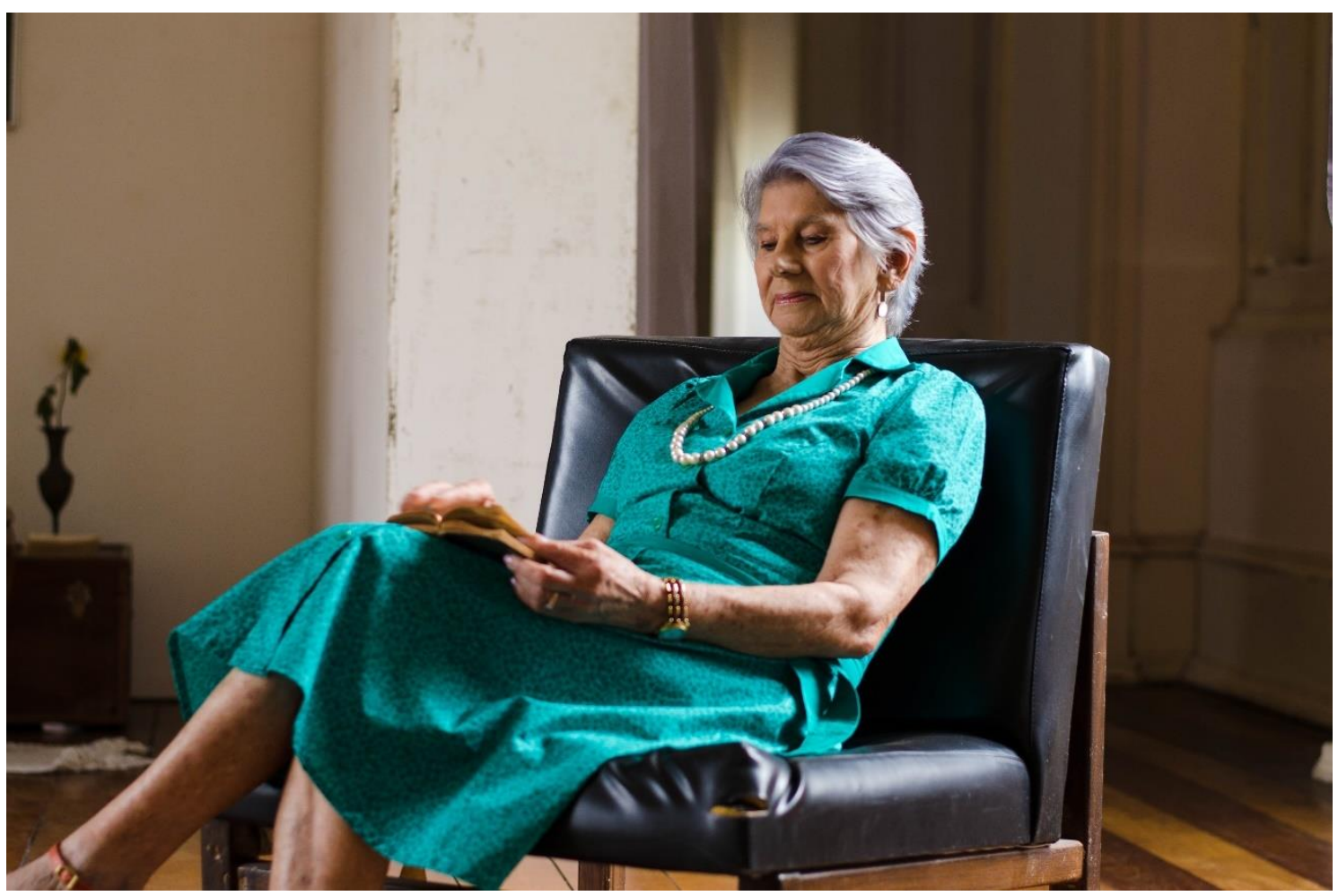

Foto: Maycon Soldan, 2016.

Também na memória de Isaura (figura 39) vemos um traje que faz parte de uma memória feliz, sua recuperação de saúde, segundo ela, "uma felicidade que me marcou muito" (idem). Ela então recria o traje para celebrar aquele momento.

65 Disponível em: https://memoriasvestidas.tumblr.com/post/160033055835. Acesso em 04 dez. 2020. 


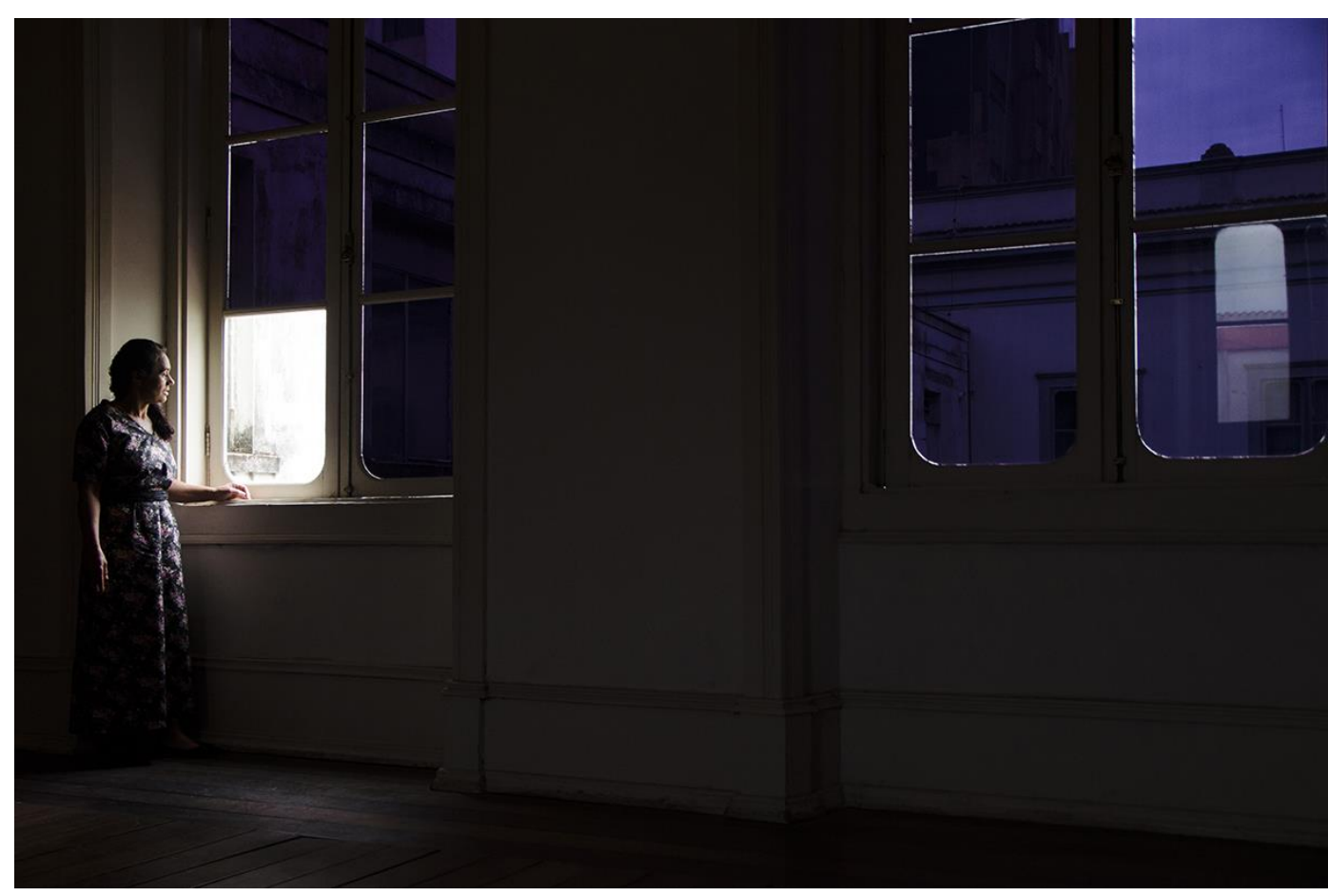

Foto: Maycon Soldan, 2016.

O desfile ${ }^{66}$ dos trajes criados durante o projeto foi tão importante para as participantes exatamente por ter sido esse momento de celebração dessas vidas, as delas próprias ou das pessoas a quem estavam homenageando, trazendo elaborações sobre trajetórias pessoais: "O que percebo em mim quando vejo as imagens do presente ou evoco as do passado?" (BOSI, 1994, p. 6). Esse olhar atencioso é semelhante ao da criança que acredita que reproduzindo traços físicos ou da indumentária de um outro, gere então a identificação com aquele outro, ao reelaborar memórias e incorporar experiências alheias (MENESES, 1994, p.12). Em conversa informal, uma participante chamou o curso de "Memórias Revestidas", o que sublinha o caráter de recriação e reelaboração das memórias e seus detalhes precisos, imaginados ou vividos.

66 Vídeo do desfile disponível em https://www.youtube.com/watch?v=R7ufSu9P-iM\&t=150s, acesso em 4 de dezembro de 2020. 


\section{Capítulo 4 - Para aquelas que não estão}

Gosto de pensar nas caixas de costura como formas de vestir, como devires. Elas são projetos inacabados de roupas, e, muitas vezes, acumulam-se ali fragmentos de ideias e matérias que jamais tomarão corpo. Nelas são depositados planos futuros de roupas ainda sem forma, vestidos que estão por vir. (ANDRADE, 2008, p.33) 
Para pespontar investigações presentes nos capítulos anteriores, nos parecia necessário um trabalho criativo-poético, onde se colocam em prática as reflexões levantadas. A experiência que fomenta este capítulo é o processo de criação do traje de cena do espetáculo teatral Como se Fosse, do Grupo Matula Teatro ${ }^{67}$. Aqui, o traje se mostrou não apenas disparador do traje de cena, que nasce a partir da roupa de segunda mão, mas também suporte da narrativa, como iremos detalhar.

A peça de teatro Como se Fosse conta a história de um feminicídio executado pelo marido de uma costureira, que usa como arma do crime a tesoura da vítima, seu instrumento de trabalho. A peça se serve de uma dramaturgia que mescla dados documentais trazidos pelo grupo ao texto de Gracia Morales, dramaturga espanhola.

\subsection{Construindo o figurino}

Este processo se serve de trajes sociais tanto para seu figurino, quanto para o cenário. Como a figurinista é também a autora desta pesquisa, havia a proposta de que o traje de cena tivesse origem a partir de trajes sociais, tanto a memória ou fotografias das épocas retratadas, quando objetos existentes, como roupas de segunda mão que seriam garimpadas para fazer parte do figurino. Relevante mencionar que já havia toda uma construção sobre como fazer escolhas quando o traje já existe, ou seja, quando o material é a roupa de segunda mão, que já tem uma cor, uma textura, uma modelagem, que claro, podem ser customizadas, mas não entregam a mesma independência que um tecido aliado a um desenho técnico podem oferecer. Essa já é uma metodologia que desafia a autora, que para tanto desenvolveu estratégias que envolvem pintura do tecido em outras cores (figura 40), reformas, bordados, todo um arsenal de customizações para que a peça de roupa faça parte, de forma coerente, da proposta para um traje de cena.

\footnotetext{
67 A peça estreou em 14 de março de 2020, na semana anterior ao isolamento decretado pela crise do Corona Vírus. Disponível em www.grupomatulateatro.com/projeto-como-se-fosse/. Acesso em: 04 jan. 2021.
} 
Figura 40 - Trajes secam após tintura

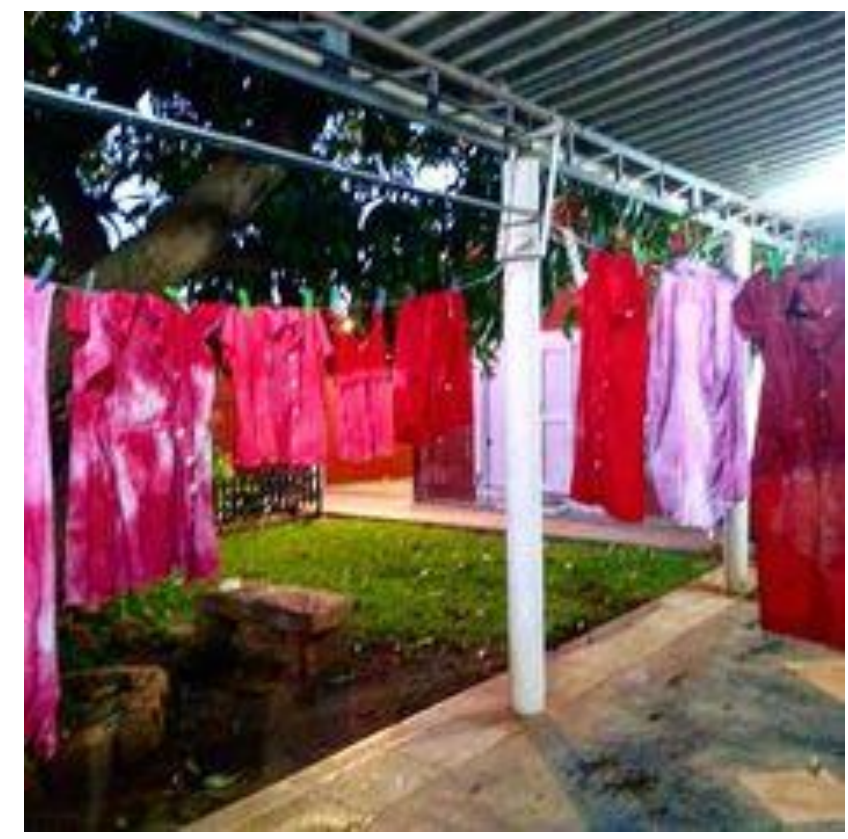

Foto: Acervo da autora, 2020

Durante o processo da procura por roupas de segunda mão que fossem coerentes com o projeto, em um dos bazares, figurinista e atrizes encontram uma roupa que havia pertencido a avó de uma das atrizes, falecida a pouco tempo, e a família havia doado seus pertences. No meio das roupas das pilhas dispostas no bazar, nos deparamos com a memória que aquele traje emanava, "porque a roupa é capaz de carregar o corpo ausente, a memória” (STALLYBRASS , 2012, p. 26).

Uma das peças foi confeccionada para aquele figurino, mas tinha origem na memória da figurinista, uma saia que havia existido em seu acervo, e que faria sentido dentro da proposta. Como a peça não existia mais, foi então confeccionada, seguindo detalhes que restavam daquela memória: uma saia de cor vinho, com cós, com bolsos, de comprimento até o joelho (figura 41). A peça não havia sobrevivido como objeto, mas a lembrança de como ela era dispara a criação daquele traje, como no capítulo anterior, no processo do projeto Memórias Vestidas. 

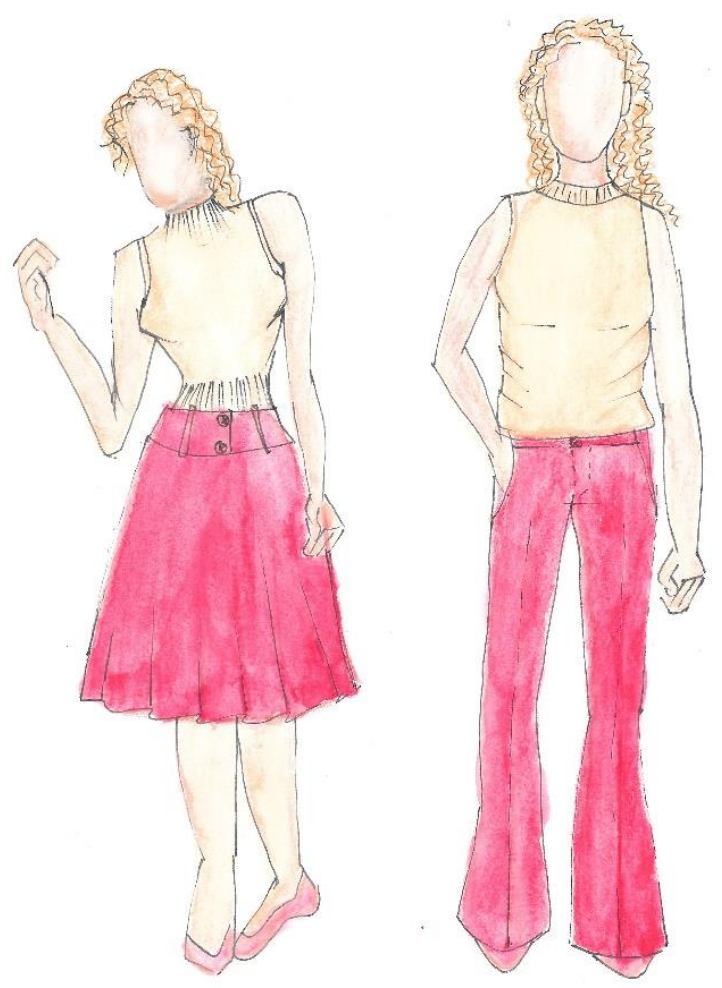

Foto: Acervo da autora, 2020

Nota-se pelo croqui (e pelas fotos, ao longo do capítulo) que havia semelhanças visuais entre as duas atrizes, como a cor da pele e dos cabelos. Escolheu-se então que tais semelhanças fossem trabalhadas também nas cores e na parte superior do traje, e suas diferenças fossem pronunciadas pelas tipologias (uma das atrizes usa saia, a outra usa calça) e na diferença sutil das nuances de cor das peças.

Um acontecimento no ano de 2020 sugeriu mais uma camada possível de significado para as blusas escolhidas. Um detalhe que se repete na tipologia de ambas as peças do figurino é a questão da gola alta. Inicialmente, as blusas foram escolhidas e compradas em bazares por suas cores e o toque da textura, mas as golas altas podem fornecer uma leitura de um silenciamento, que a violência e o feminicídio trazem, ao aprisionar gargantas. Essa leitura foi traçada 
a partir da repercussão de uma fala de Philonise Floyd, em junho de 2020, por conta da morte do irmão, George Floyd. Ele comparece à corte americana para depor impecável em roupa social, porém, de camisa desabotoada, sem uso da gravata, como ele fez nos dias seguintes à morte do irmão. Segundo Floyd, quando o irmão grita a frase que depois é largamente usada em protestos, "eu não consigo respirar" ( $/$ can't breathe, tradução nossa), ele não consegue mais usar gravatas: "Eu não queria mais usar gravata porque queria poder respirar"68. Essa postura em relação ao traje nos parece fornecer uma leitura possível a nossas blusas femininas de gola alta, que podem dizer "eu quero contar minha história, mas não posso falar".

Trabalhar com roupas de segunda mão dentro de um contexto de feminicídio também nos lembrou da relação entre traje feminino e culpa, como vemos na exposição, ocorrida na Bélgica em 2018, ${ }^{69}$ com roupas usadas por mulheres quando foram violentadas. Chamada "A Culpa é Minha", a triste realidade mostrada por aqueles trajes é que são roupas apenas normais, de maneira nenhuma um convite a violência. Esse dado foi impossível de ignorar durante a criação.

\subsection{Imagens de homenagem e assombração}

Não à toa, os dados de violência e essas imagens podem nos assombrar, ao evocarem certo "terror do traço material" (STALLYBRASS, 2012, p.17). Nomes das vítimas de feminicídio foram bordados nos trajes sociais (Figura 42) e evocaram suas memórias e as homenagearam, fazendo parte da construção de uma história social e coletiva. Veronica Fabrini, diretora do espetáculo, em entrevista (entrevista, apêndice B) cita um ditado chileno sobre cada ponto do bordado ser uma cura, "cada punto uma sanacion70", algo que Boeira (2018, p.53) se refere como "um aspecto mágico bordado ao traje", que estaria presente em aspectos rituais do bordado, o que também veremos na entrevista com

\footnotetext{
68 Tradução nossa, reportagem do WashingtonPost. Disponivel em: https://www.washingtonpost.com/lifestyle/2020/06/10/philonise-floyd-george-brother-congress/. Acesso em: 20 abr 2020.

69 Disponível em: https://www.hypeness.com.br/2018/01/culpa-da-mulher-exposicao-mostraroupas-usadas-por-vitimas-de-estupro-na-hora-do-crime/. Acesso em 3 abr 2020.

${ }^{70}$ Cada ponto uma cura, tradução nossa.
} 
Fabrini: "os nomes das pessoas bordados nas roupas vão adquirindo uma qualidade quase de elementos mágicos, (...) podemos olhar como ao mesmo tempo uma mortalha e uma homenagem, e também uma presença" (entrevista, apêndice B). Podemos ver nas figuras 42 e 43:

Figura 42 - As atrizes em cena do espetáculo

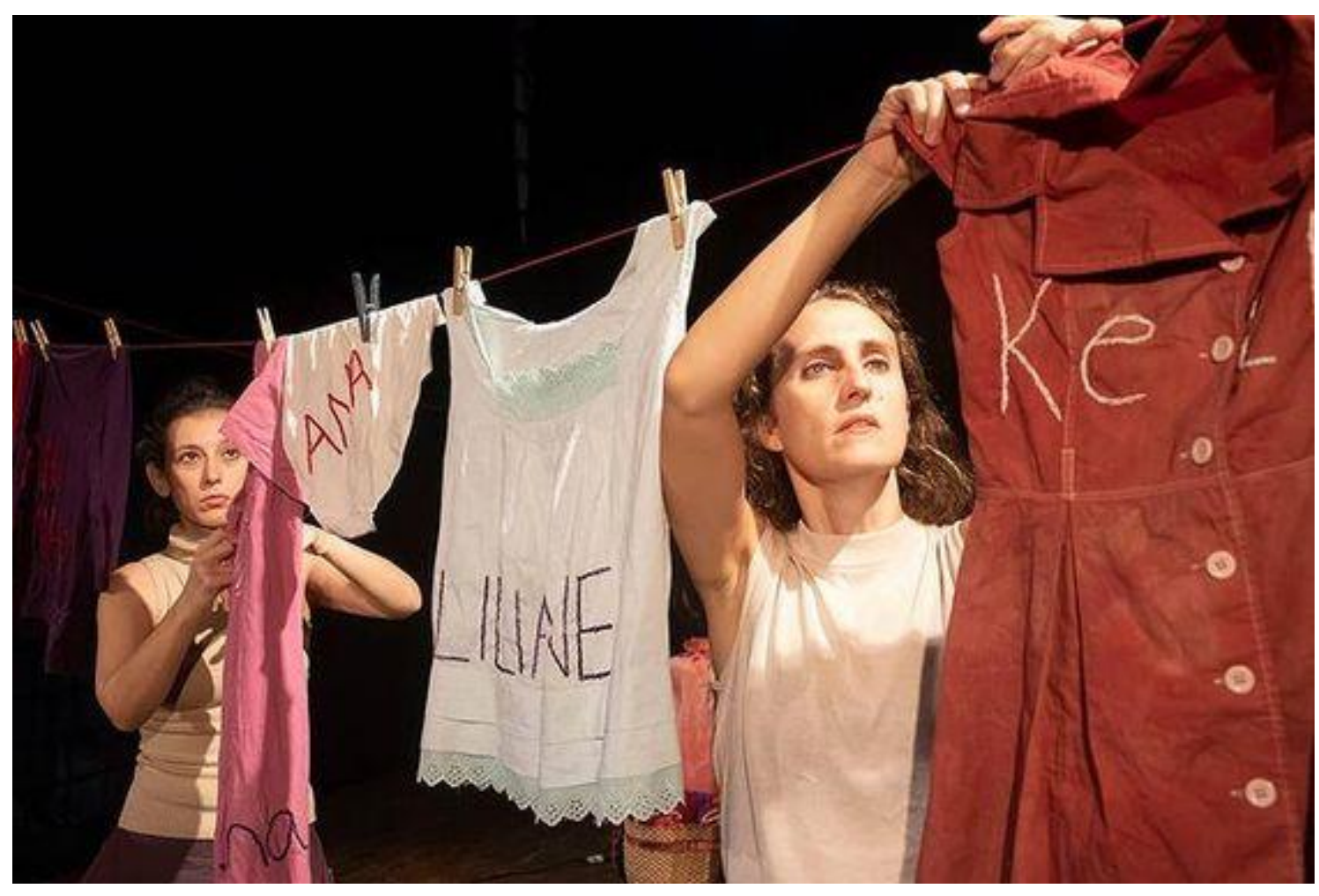

Foto: Maycon Soldan, 2020. 
Figura 43 - Traje bordado para o cenário

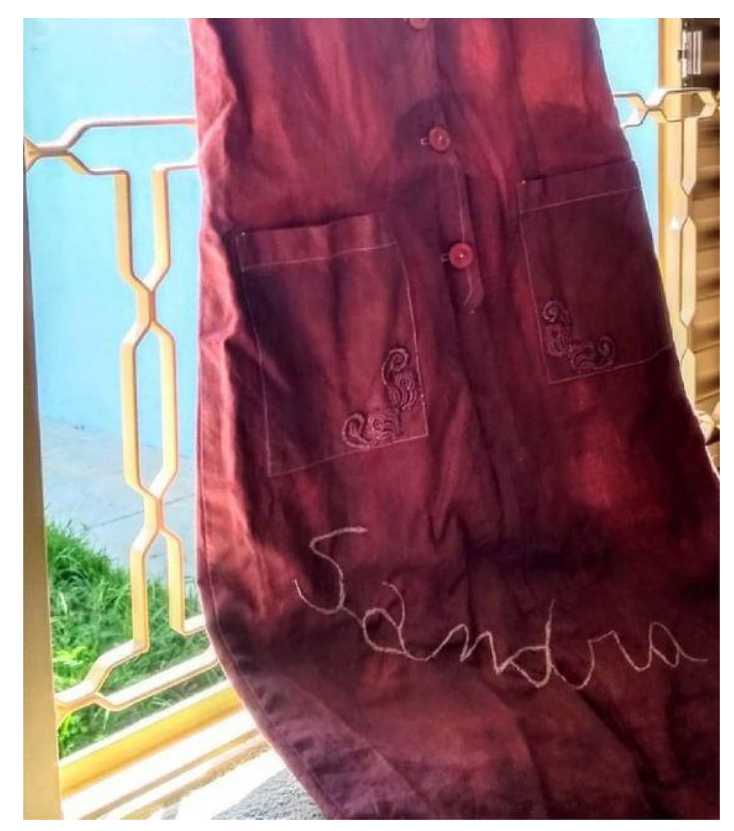

Foto: Acervo da autora, 2020

Durante uma palestra, Fabrini se refere a esse tipo de obra (performance ou cena teatral) como homenagem "para aquelas que não estão" (informação verbal) ${ }^{71}$. Esses corpos ausentes, pela primeira vez no trabalho da autora com figurino, após anos trabalhando com roupas de segunda mão, são pronunciados pela presença das antigas donas daqueles trajes e dos nomes bordados, "não são apenas dados ou estatísticas, são pessoas, então acho que essa ideia do bordado dos nomes vai desde a energia colocada em cada ponto" (Verônica Fabrini, entrevista, apêndice B). Impossível não concordar com Fabrini. O luto relacionado ao traje mencionado durante o capítulo 3, que surge no projeto Memórias Vestidas, aqui se manifesta de maneira pronunciada, uma vez que podemos ler os nomes daquelas infelizes mulheres, presentes dessa vez em trajes que compõem a cenografia da peça, trazendo força narrativa e documental a cena, "um bordado criado para um objeto do cotidiano e que é aplicado num traje e, por isso, ganha novos significados" (BOEIRA, 2018, p. 34).

\footnotetext{
${ }^{71}$ Fala de Veronica Fabrini durante palestra em 2018.
} 


\subsection{Trajes e o tempo}

O projeto de figurino em Como se Fosse não é exatamente de época, mas situa a narrativa em outro tempo, que não é tão distante do contemporâneo, mas não é o tempo do agora. O público reconhece como algo familiar, mas já nostálgico, com uma atmosfera de álbum de família desbotado. Na entrevista com Verônica Fabrini (entrevista, apêndice B), ela nos diz que esta é uma informação importante para a cena, um traje que a memória reconhece como não sendo algo de agora, portanto acaba criando uma continuidade temporal mudam-se os trajes, mudam-se os tempos, e aquela situação de violência continua ocorrendo. O espectador pode então contextualizar a cena como "não só uma história pessoal, como também uma história social" (Verônica Fabrini, entrevista, apêndice B), algo muito caro para aquela dramaturgia, onde o traje de cena a partir do traje social terá papel fundamental nesse reconhecimento do dado cotidiano. Como este figurino não é solene ou conceitual, permite que o espectador se identifique e se enxergue como próximo daquela história, sujeito a ser vítima ou agressor. Fabrini vai nos dizer que este traje de cena construído a partir do traje social ajuda a elaborar essa ideia, já que não é algo completamente distante de nosso cotidiano:

\footnotetext{
permite você tanto estar presente na ficção, por conta da harmonia deles com o cenário, ou com a característica das personagens, mas ele também permite você sair da ficção sem causar um degrau muito grande [...] acho que um figurino que permite esse trânsito sem um degrau muito chocante, ele facilita esse trânsito (Verônica Fabrini, entrevista, apêndice B)
}

Essa seja talvez uma necessidade do traje de cena dessa peça e de outras semelhantes, quando é proposto um figurino que não está tão longe de nosso cotidiano, que pode trazer identificação com dados documentais se executado de forma coerente, como proposta e não precariedade. 


\subsection{Inundação vermelha}

A escolha das cores das visualidades da cena em Como se Fosse são rondadas por uma tonalidade frequentemente associada a violência: o vermelho. O tom aparece nos diálogos da peça, quando uma das personagens se descreve "vermelha feito um tomate", bem como ronda o tema: vermelho sangue, vermelho sujo, tons associados ao feminino e a violência. Como já mencionamos, quando se trabalha com roupa de segunda mão, fica mais difícil escolher uma cor específica, uma vez que se trabalha com o que já existe. Muitas vezes, a cartela de cor emana do que foi pesquisado e está disponível para aquele traje de cena, peças pré-existentes podem guiar escolhas narrativas, mesmo que o figurinista procure por uma paleta de cor específica. Os trajes podem ser tingidos, o que não funciona exatamente como definir uma cor exata e comprar o tecido segundo aquela escolha.

Havia uma relação com o movimento feminista Ni Una a Menos ${ }^{72}$, que milita pelos direitos das mulheres e tem as cores roxo e verde como símbolos, que inclusive estão presentes em algumas peças de roupa do cenário. Mas 0 vermelho emergia a todo momento, por mais que se tentasse fugir dele como escolha óbvia, sanguínea, ele foi trabalhado e inserido na narrativa. Verônica Fabrini nos diz:

Muitas vezes as coisas arquetípicas ficam óbvias, tem uma força de comunicação muito grande, vai muito da maneira com que isso dialoga com todo o resto, então claro que se fica no fácil do vermelho, pode cair no estereótipo, no óbvio da coisa. Querendo ou não, nossa, o vermelho ele evoca muito, quer a gente queira ou não, tem uma parte nossa que não é racional que lê isso, com muita vivacidade, que lê o vermelho, que decodifica o vermelho, se a gente eliminar a camada da razão e for para camadas mais arcaicas, o vermelho tem essa

\footnotetext{
${ }^{72} \mathrm{Ni}$ uma a menos é um movimento de luta feminista que atua na América Latina e surgiu na Argentina em 2015. Disponível em: https://agenciabrasil.ebc.com.br/direitoshumanos/noticia/2017-03/fundadora-do-ni-una-menos-diz-que-luta-contra-violencia-machista. Acesso em 21 mar. 2020.
} 
potência e que mais até que ligado a todos os sentidos que ele tem, do sangue, da morte, estou pensando aqui o vermelho como cor do chakra básico, é a cor da encarnação, é a cor do 'estou presente no mundo material e por estar presente no mundo material eu estou suscetível ao que nele ocorre', estou preso nas dimensões e espaços temporais da existência corpórea. [...] Acho que faz bastante sentido, pensando até nessa relação sobre a vibração da cor, é a que nos liga a materialidade, e claro, dentro disso, ela não fica presa aí, ela sobe, ela se evapora, ela se mistura, ela se tinge. Até esse apagado que ela vai ficando, acho bonito, porque ela vai ficando quase que contaminada por um mundo cinzento, que perdeu a vitalidade (Verônica Fabrini, entrevista, apêndice B)

Dessa maneira, podemos ler o figurino em que a parte de baixo é vermelha e a parte de cima vai perdendo a cor, tornando-se bege, acinzentada, como uma vitalidade que vai indo embora, como no corpo sem vida, que é cinza, que perde calor.

\subsection{Presença das imagens da costura}

Ao longo do processo desse figurino, abrimos diversas caixas de costura, abstratas e figuradas, que nos pediam carinho e cuidado. Impossível ignorar a imagem arquetipicamente feminina do universo da costura que os objetos de cena presentes evocam: vemos linhas, dedal, moldes, tecidos, pano, fita métrica, mesmo a própria tesoura, tão fundamental à história. 
Figura 44 - Objetos ligados ao universo da costura

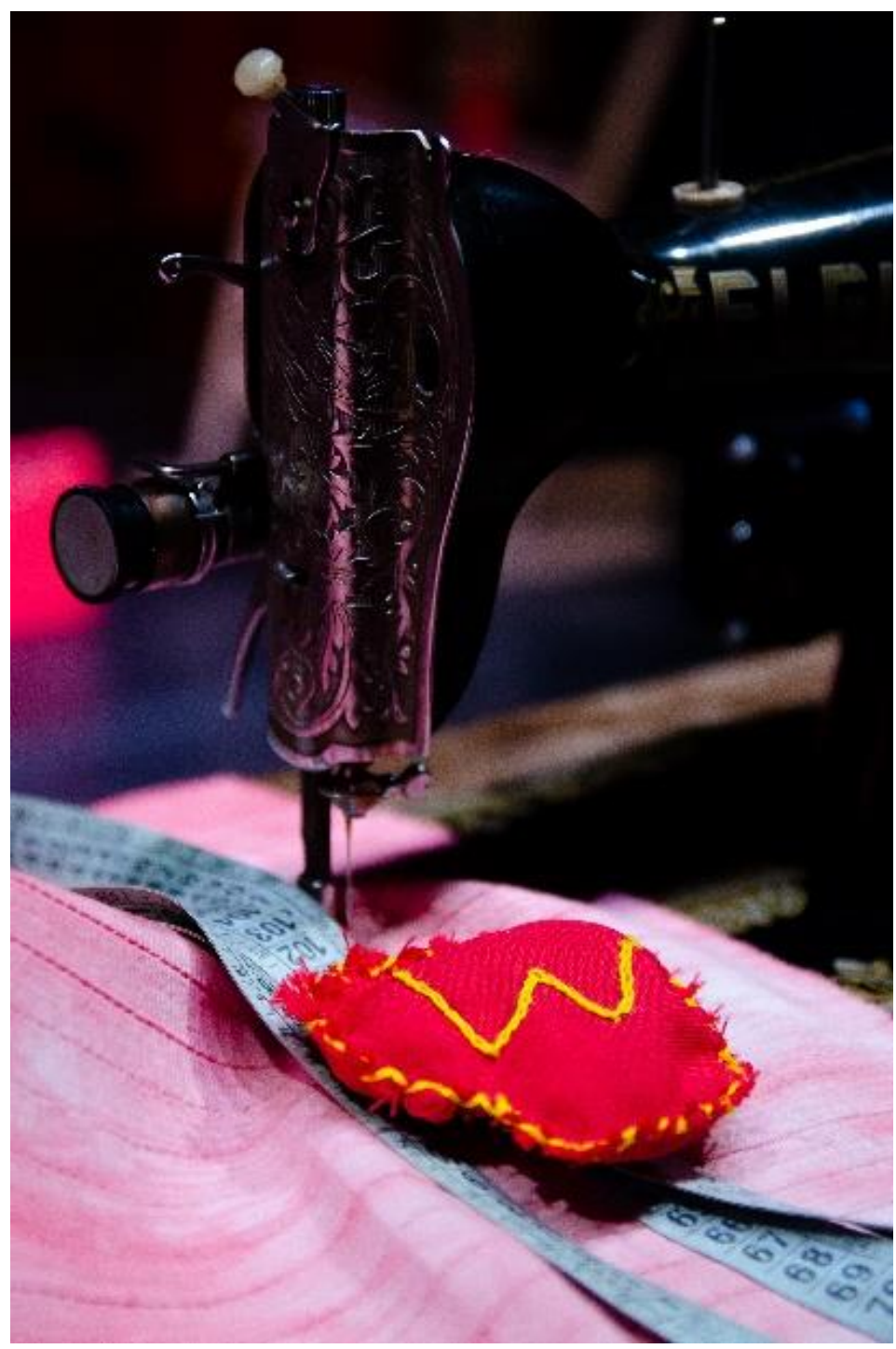

Foto: Maycon Soldan, 2020.

Termos ligados ao universo da costura são caros para a diretora Verônica Fabrini, que assim como Bosi (1994) e outras autoras que fazem parte da nossa bibliografia, convoca esses termos ligados a cultura vestimentar o tempo todo como metáforas. Observamos com apreço essas analogias com o têxtil, que de certa forma ajudam a compor nossa modelagem, fazem parte de "todo esse mistério do molde" (Verônica Fabrini, entrevista, apêndice B).

Um objeto ligado a costura que se faz presente em cena na peça Como se Fosse é o dedal, "uma proteção tão delicada, quase que uma metonímia do 
assassinato com a tesoura" (Verônica Fabrini, entrevista, apêndice B). Uma preocupação realista sobre o uso atual da ferramenta dedal foi observada pela autora desse texto durante o processo, se o público reconheceria aquele objeto como de uso corrente de uma costureira, se talvez o objeto não teria caído em desuso. Essa preocupação foi obviamente descartada após ensaios.

O processo de criação desse traje de cena colocou em movimento as reflexões levantadas sobre o traje social cotidiano ser colocado em contextos artísticos. Viver a experiência desse figurino e escrever sobre o processo foi maneira potente de concretizar a costura como estratégia narrativa. 


\section{Conclusão}

Durante toda essa escrita, nos confrontamos com ideias contrárias que poderiam emergir do traje, como um certo luto ou assombração, em oposição a celebrações e homenagens. Observamos essas características, que podem carregar potência às cenas em que são inseridas, não apenas como tristes ou alegres, mas como parte da narrativa. Existe sim luto, mas tais memórias podem sinalizar celebração e potência de vida. Muitas vezes, a característica do luto parecia emergir dos estudos de caso quase sem querer, então era preciso abrir a perspectiva para outras presenças.

Notamos também um importante papel do traje de cena quando se dá a partir do traje social: estabelecer cronologias. Quando ligado à memória, o traje nos situa em outros tempos, se é necessário para a obra artística, ele nos ajuda a construir o aspecto temporal, sobre qual época aquela história se refere. Nas obras analisadas durante os capítulos dessa dissertação, podemos notar informações cronológicas, contemporâneas ou de um passado, "que ainda ontem constituía o mais trivial cotidiano?" (PELBART, 2000, p.6). Quando no presente, o traje pode situar se a pessoa está em casa, está na rua, trabalhando ou confraternizando. Também traz importantes informações sobre quem o veste, indicando faixa etária, classe social, gênero, fazendo parte de uma "matéria prima tão impalpável quanto incontornável a que chamamos de subjetividade" (idem, p.6).

Durante o contato com os estudos de caso, vimos o arquétipo feminino pulsar, uma generificação inscrita através de papéis sociais, como nos diz Stallybras:

Fora do mercado capitalista, onde o tecedor masculino e o alfaiate masculino tornaram-se, crescentemente, a norma, eram as mulheres que eram tanto material quanto ideologicamente, associadas com a confecção, o conserto e a limpeza das roupas. É difícil recapturar plenamente a densidade e a complexa transformação entre as mulheres das diferentes classes e a roupa. Mas durante a maior parte do período inicial da Europa Moderna e das Américas, a vida social das mulheres esteve profundamente conectada a vida social da roupa. (STALLYBRASS, 2012, p.23) 
Notamos essas relações em imagens interessantes, como no segundo capítulo, quando a performer narra uma epifania ao lavar roupas intimas, ou ainda quando uma das participantes do projeto analisado no terceiro capítulo descreve seu ritual de lavagem com amaciante para perfumar e ressignificar trajes comprados em bazar. No capítulo 4, vemos a imagem do varal, ou ainda a profissão costureira de uma das personagens, além de menções ao cotidiano doméstico nos diálogos. Verônica Fabrini (entrevista, apêndice B) associa os fios da vida, presentes da figura mitológica das Moiras, ao varal que é visto em cena, uma camada arquetípica que se soma àquela cena.

Não por acaso, esse cuidado com o vestir, de confeccionar e cuidar, é muitas vezes relegado ao gênero feminino, não como escolha, mas como imposição infeliz. Nossa observação se constrói de forma crítica, não uma aceitação tranquila e poética. Mesmo não sendo um alvo de nosso olhar, essa questão nos espreita e assombra, em diversos contextos. O traje também vai sublinhar essa "diferenciação" de gêneros, como por exemplo a tipologia da saia, que será associada ao feminino ao longo dos últimos séculos. Nesse momento, o conceito de performatividade se mostra não apenas no seu sentido artístico, mas também muito ligado a performar um gênero como construído culturalmente.

Esses pontos foram alinhavados a partir dos estudos de caso que guarnecem os capítulos. Cada contexto analisado nos ajuda a sugerir que o traje de cena, quando é criado a partir do traje social, motiva o acesso não só a memórias que serão potentes para aquela cena, como também subjetividades que são performadas por aqueles trajes.

No primeiro capítulo, abrimos um olhar amplo para outras obras, de artes visuais e cênicas, o que nos fez observar diversas ocasiões em que o traje social fez parte da obra artística, com que características, ou porque fez parte, que intenções vimos. Aqui o luto já nos assombra, mas questões de identidade pulsam em primeiro plano. Vemos o traje como testemunha de uma época ou acontecimento, bem como significados que o levam a um contexto artístico.

Quando em nosso segundo capítulo nos defrontamos com Descaracterizar-se, trabalho da performer Beatriz Cruz, e as pessoas participantes da performance que são os donos daquelas roupas que ela veste, 
observamos que o traje não é neutro. Mesmo quando o participante afirma não ter pensado exatamente naquela troca, ou quando usa uniformes, não existe uma neutralidade ou invisibilidade. As subjetividades afloram, não passam despercebidas, bem como demonstram uma linha clara que faz demarcações sociais e culturais. A performance escancara o traje como construção de uma identidade, onde se pronunciam diversos elementos, como por exemplo a condição social, idade e gênero, entre outros. Aquilo que já é muito pronunciado no traje social, notamos em caixa alta no traje da performance.

Nos trajes recriados a partir de memórias no terceiro capítulo, vimos narrativas autobiográficas ou de biografias próximas, onde o gênero, a infância e as relações familiares são temas principais. No projeto Memórias Vestidas, as lembranças são ficcionalizadas, atravessadas por afetos, pelo olhar e a narrativa alheia sobre elas, "É preciso reconhecer que muitas de nossas lembranças, ou mesmo de nossas ideias, não são originais: foram inspiradas nas conversas com os outros" (BOSI,1994, p. 331). Notamos diversas semelhanças com a criação de trajes de cena, de contextos espetaculares em que existe dramaturgia, o que não havia em memórias Vestidas, embora tenha ocorrido uma finalização onde as participantes posaram para fotografias que foram expostas ao público e desfilaram os trajes (re)criados, havia então uma característica de performance, que entendemos a partir da leitura de Schechner, especialmente quando lemos "mostrar-se fazendo" (2003, p. 26). Cada uma das memórias vestiu uma subjetividade, para então ter sido performada pelas participantes. Ao final do projeto, as integrantes carregaram consigo as peças produzidas e puderam usar as peças em suas vidas cotidianas, reuniões familiares, igrejas e todo tipo de evento social que frequentem.

No derradeiro e quarto capítulo, cerzimos com uma experiência prática de traje de cena, para o espetáculo teatral Como se Fosse. Aqui o traje social foi a princípio suporte do figurino, porém disparador do objeto cenográfico varal, presente no cenário da peça, onde as peças de roupa penduradas foram bordadas com nomes de mulheres que infelizmente integram estatísticas de feminicídio. O caráter de certo assombro inundou esse processo artístico, para além do luto, havia indignação e inconformismo ao contar, por meio daqueles trajes, a dramaturgia que envolvia o espetáculo. Durante o desenvolvimento 
dessa obra, entendemos como o traje pôde ajudar a apresentar a história de uma personagem que vive do ofício da costura e sua filha anos depois, afora o trágico dado do feminicídio.

Arrematamos esta pesquisa com a ideia de que o traje social pode atuar não só como disparador, como ponto de partida de um traje de cena, mas também como suporte narrativo, que convoca e demonstra memórias, subjetividades e performatividades. Presente em nosso cotidiano, em memórias do passado, ou em um futuro imaginário, o traje pode disparar e fazer parte de poéticas cênicas e subjetividades contemporâneas. 


\section{Referências bibliográficas}

ALEKSIÉVITCH, S. A guerra não tem rosto de mulher. Tradução de Cecília Rosas. $1^{\underline{a}}$ ed. São Paulo: Companhia das Letras, 2016.

BOSI, Ecléa. Memória e sociedade: lembranças dos velhos. São Paulo: Companhia das Letras, 1994.

BUTLER, Judith. Problemas de gênero. Feminismo e subversão de identidade. Tradução de Renato Aguiar. Rio de Janeiro: Civilização Brasileira, 2010.

CARVALHO, Flávio. A Moda e o Novo Homem. SIBILA Revista semestral de poesia e cultura: ano 04, número 06, p. 188-207, maio de 2004.

FÉRAL, Josette. Além dos limites: teoria e prática do teatro. São Paulo: Perspectiva, 2015.

Encontros com Ariane Mnouchkine: erguendo um monumento ao efêmero. São Paulo, Editora SENAC São Paulo: Edições SESC SP, 2010.

FERNANDES, Silvia. Teatralidades Contemporâneas. São Paulo: Perspectiva, 2010.

XIX DE TEATRO, Grupo. Hysteria | Hygiene. São Paulo: Prêmio Funarte Petrobrás de Teatro Myrian Muniz, 2006.

LE GOFF, Jacques. História e memória. Tradução Bernardo Leitão ... [et al.] -Campinas, SP Editora da UNICAMP, 1990.

PELBART, Peter Pál. A Vertigem por um Fio: Políticas da Subjetividade Contemporânea. São Paulo: lluminuras/FAPESP, 2000.

SCHECHNER, Richard. O que é performance. O Percevejo: Revista de teatro, crítica e estética. Rio de Janeiro: UNIRIO; PPGT; ET, Ano II, n.12, pág. 25-50. 2003. 
SOUZA, Gilda de Mello e. O Espírito das roupas. São Paulo, Cia. das Letras, 1987.

STALLYBRASS, Peter. O casaco de Marx: roupas, memória, dor. 4ํㅡ. Ed. Belo Horizonte: Autêntica Editora, 2012.

SVENDSEN, Lars. Moda: uma filosofia. Rio de Janeiro: Zahar, 2010.

SZYMBORSKA, Wislawa - [Poemas]. Trad. Regina Przybycien. São Paulo: Companhia das Letras, 2012.

VIANA, Fausto Roberto Poço. O figurino teatral e as renovações do século XX, 1a edição, São Paulo: Estação das Letras e Cores, 2010.

. O traje de cena como documento. São Paulo: Estação das Letras e Cores, 2015

Para documentar a história da moda. São Paulo: ECA /

USP, 2017.

\section{Recursos Eletrônicos}

ANDRADE, Rita Morais de. Boué Soeurs RG 7091: a biografia cultural de um vestido. 2008. 224 f. Tese (Doutorado em História) - Pontifícia Universidade Católica de São Paulo, São Paulo, 2008.

BOEIRA, Maria Celina Gil Reis. Os potenciais narrativos do bordado no traje de cena. 2018. Dissertação (Mestrado em Teoria e Prática do Teatro) - Escola de Comunicações e Artes, Universidade de São Paulo, São Paulo, 2018.

BOUVET, Marie Hélene. Os figurinos de Les Éphémères. São Paulo, Revista Sala Preta, 7, 117-122, 2007. 
FABIÃO, Eleonora. Programa Performativo: o corpo-em-experiência. Revista do LUME, n4, 2013.

FÉRAL, Josette. Por uma poética da performatividade: 0 teatro performativo. In: Revista Sala Preta, São Paulo, no 8, 2008. p. 197-210. Tradução: Lígia Borges.

FERNANDES, Silvia. Teatralidade e Performatividade na Cena Contemporânea, in: Repertório: Teatro \& Dança, Salvador, n¹6, 2011. p. 1123.

KUHL Anna Theresa; PRUDENTE, Aline Barbosa da Cruz. Memórias Vestidas: (re)criação de moda a partir da memória. Revista de Moda Anchiote. v. 4, № 2. Belo Horizonte: Setembro/ Dezembro, 2016.

MENESES, Ulpiano T. Bezerra. Do teatro da memória ao laboratório da História: exposição museológica e o conhecimento histórico. Anais do Museu Paulista. São Paulo, 1994.

PEREIRA, Dalmir Rogério. Alinhaves entre traje de cena e moda: Estudos a partir de Gabriel Vilela e Ronaldo Fraga. São Paulo: Universidade de São Paulo; Dissertação de Mestrado em artes cênicas; Fausto Roberto Poço Viana, 2012.

POSSANI, Maria Alice. $\mathrm{O}$ ator em jogo: tessituras entre corpo, cena e cidade. Tese (Doutorado) - Universidade Estadual de Campinas, Instituto de Artes, 2017.

REBOUÇAS, Renato Bolelli. A construção da espacialidade teatral: os processos de direção de arte do grupo XIX de teatro. 2010. Dissertação (Mestrado em Teoria e Prática do Teatro) - Escola de Comunicações e Artes, Universidade de São Paulo, São Paulo, Brasil, 2010. 
SANT'ANNA, Patrícia. Coleção Rhodia do MASP - Um estudo sobre o design de vestuário no Brasil (1959-1972). 2010. Tese (Doutorado em História da Arte). Universidade Estadual de Campinas, UNICAMP, Brasil, 2010.

SEQUEIRA, Rosane Preciosa; ANDRADE, Rita Morais De. A roupa em conexão com ações poéticas e políticas. REVISTA D'OBRAS (ONLINE), v. 10, p. 6-20, 2017.

SEQUEIRA, Rosane. Rumores discretos da subjetividade. Tese de Doutoramento. São Paulo: PUC-SP, 2002.

VELLOSO, Isabela Monken; VIANA, F. R. P. Roland Barthes e o Traje de Cena [recurso eletrônico].São Paulo: ECA-USP, 2018.

\section{Webgrafia}

DADA, Carlos; RAMOS, Fred. O último traje. Revista Piauí, ed. 99, 2014. https://piaui.folha.uol.com.br/materia/o-ultimo-traje/. Acesso em 04 jun 2019.

KÜHL, Anna Theresa; PRUDENTE, Aline Barbosa da Cruz. Memórias Vestidas: Reconstrução de Indumentária: registros escritos e imagéticos. Registros escritos e imagéticos. 2016. Disponível em: https://memoriasvestidas.tumblr.com/. Acesso em: 04 dez. 2020.

NEGREIROS, Hanayrá. Histórias do Vestir: cinco artistas negros no acervo do masp. cinco artistas negros no acervo do MASP. 2020. Disponível em: https://masp.org.br/masp-escola/historias-do-vestir. Acesso em: 04 dez. 2020.

CRUZ, Beatriz. Rede social do projeto Desandar na plataforma instagram. Disponível em: https://www.instagram.com/projetodesandar/. Acesso em: 05 jul. 2020. 
RAMOS, Fred. Site do fotográfo Fred Ramos. Disponível em: https://fredramos.com/. Acesso em: 05 jul. 2020.

PROJETO DESANDAR. Site do Projeto Desandar. Disponível em https://projetodesandar.weebly.com. Acesso em: 05 jul. 2020.

KÜHL, Anna Theresa; PRUDENTE, Aline Barbosa da Cruz. VID: Estúdio Criativo. 2017. Disponível em: https://videstudiocriativo.blogspot.com/. Acesso em: 04 dez. 2020. 


\section{Anexo I}

Projeto "Memórias Vestidas: Reconstrução Poética de Indumentária", conforme enviado ao "CONCURSO DE APOIO A PROJETOS DE ARTES INTEGRADAS II NO ESTADO DE SÃO PAULO”, no ano de 2015

1. Linguagens, estéticas, proposições abordadas - História da Moda, Artes Visuais, Fotografia. Memória e valorização da história cultural dos participantes.

2. Núcleos artísticos participantes: VID Estúdio Criativo.

3. Formatos e/ou meios de produção: Elaboração de um traje/peça de vestuário, exposição fotográfica e de processo de criação.

4. Regiões atendidas: Região Metropolitana de Campinas

Objetivo do projeto

Objetivos Gerais

- Desenvolver uma oficina de reconstrução histórica e poética de um traje, a ser desenhado a partir das memórias e histórias dos(as) participantes idosos;

- Realizar uma exposição a partir dos resultados da oficina, se servindo de uma sessão fotográfica com os trajes produzidos e caracterização de cabelo e maquiagem, além de uma curadoria da documentação do processo criativo e os trajes expostos em manequins.

\section{Objetivos Específicos}

- Promover uma atividade que integra artes visuais, moda e fotografia;

- Incentivar oportunidades de convivência e fruição cultural para população idosa; 
- Incentivar o compartilhamento de saberes entre gerações;

- Valorizar a autoestima e as histórias pessoais dos participantes;

- Oferecer conhecimentos e técnicas sobre o processo de criação de vestuário;

- Incentivar o pensamento sustentável a partir do uso de materiais reutilizados nas produções (roupas de segunda mão, tecidos de descarte, fim de rolo, retalhos, etc);

- $\quad$ Oferecer uma exposição com esse processo para a comunidade e a fim de promover troca de experiências e oportunidade de reflexão.

\section{Justificativa do projeto}

Segundo o artigo "Hábitos Culturais dos Paulistas" , publicado em julho deste ano, a população idosa é considerada a mais excluída em termos de consumo cultural. Uma das principais motivações deste projeto é a geração de oportunidades para a convivência, fruição cultural e a valorização da memória de pessoas da terceira idade.

Com o conteúdo histórico/cultural produzido durante a atividade, será feita uma exposição com uma monitoria voluntária dos participantes da oficina, para que outras gerações de jovens e adultos, que venham a visitar a exposição, tenham acesso e possam fazer uma reflexão sobre o seu próprio "tempo". Desta maneira, o projeto promove um encontro de gerações, onde o idoso tem a oportunidade de contar suas histórias, por meio do figurino e da fotografia; e o jovem/adulto tem acesso a informações históricas e conteúdo poético de forma interativa e prazerosa.

Além do encontro de gerações, este projeto também promove o encontro entre diversas linguagens artísticas, como artes visuais, moda e fotografia; passando pelo desenho, pesquisa de referências visuais, memória e valorização social, história da moda, criação de vestuário, sessão fotográfica com caracterização de cabelo e maquiagem. Este processo é finalizado em forma de 
exposição, onde estão presentes não só os trabalhos finais (traje e fotografia), mas também uma curadoria de registros do processo de criação, como a pesquisa e o caderno de artista de cada participante.

Neste projeto, também destacamos o incentivo ao uso de materiais sustentáveis, como roupas de segunda mão, que podem ser reestruturadas na forma de novos trajes; além de tecidos de reuso (adquiridos em iniciativas como o Banco de Tecido) ou de final de coleção/rolo, retalhos, entre outros, promovendo assim, o pensamento sustentável.

Onde será realizado o projeto - Cidade(s) e Local(is)

O projeto será realizado na cidade de Campinas, em parceria com a Secretaria Municipal de Cultura, no Museu da Imagem e Som de Campinas (MIS), que está localizado em área central, com fácil acesso por transporte público. Este local já conta com uma programação voltada para diversas faixas etárias, além de oferecer uma estrutura mínima para as oficinas e a exposição fotográfica.

A divulgação das vagas para a oficina vai envolver visitas a centros comunitários ou locais de convivência de idosos, para atingir públicos de diversos bairros da cidade.

Plano de Trabalho com detalhamento das atividades a serem desenvolvidas

O projeto propõe uma oficina de reconstrução de trajes históricos, a qual terá como trabalho final uma exposição mostrando os trajes criados, as fotografias dos alunos vestindo-os, além do processo de criação com cadernos de artistas e desenhos. O intuito da exposição é o diálogo com outras gerações e o espaço para reflexão sobre o nosso próprio tempo. 
A oficina é composta de duas partes. A primeira é ligada a memória e reconstrução histórica e a segunda, ao desenho e costura de uma ou mais peças de vestuário.

Nesta primeira parte haverá uma introdução sobre memória de forma poética. A partir desta introdução, os alunos recebem um caderno para os registros criativos (caderno de artista) colocando nele imagens, sentimentos, desenhos, ou seja, qualquer forma de expressão que venha junto com o resgate das memórias da vida.

Já na segunda etapa, os alunos receberão aulas de design de indumentária, como cor, textura e desenho, ao mesmo tempo em que começam a fazer pesquisas de fotos e objetos que tenham feito parte de determinado momento de sua historia pessoal, como a infância, adolescência ou começo da maturidade. Com esta pesquisa e com os conhecimentos adquiridos, os alunos desenharão um traje característico de alguma destas épocas, e a partir do desenho irão confeccioná-lo. Nesta fase a professora convidada Rosângela Rubbo auxiliará os alunos, com seus conhecimentos de modelagem, moulage e costura. Todo o processo desenvolvido durante a oficina será documentado em fotos e vídeos semanais que serão compartilhados nas redes sociais e no diário de bordo do site do projeto.

Nas aulas finais da oficina, será feita uma sessão fotográfica, em que os participantes usarão os trajes criados e contarão com caracterização de cabelo e maquiagem das profissionais Gabriela Schembeck e Cristiane Garcia. Esta sessão poderá ocorrer no próprio espaço das atividades ou em uma locação nas proximidades, podendo ser um local que se relacione ou evoque a memória do participante.

A partir dos trajes, cadernos de artista e fotos, será feita uma exposição no próprio espaço da oficina, na qual outras gerações terão acesso e poderão conhecer um pouco sobre os costumes de épocas passadas de forma poética. A exposição contará também com a monitoria dos alunos que se voluntariarem, fazendo com que ocorra uma troca entre público jovem, adulto e idoso. $O$ conteúdo da exposição estará à disposição para itinerância, de acordo com a contrapartida deste projeto. 


\section{Perfil do público-alvo}

Idosos, com idade acima de 60 anos, com interesse e alguma experiência em trabalhos manuais, principalmente artesanato e costura. 


\section{Apêndice A}

Nota: neste apêndice-entrevista optei por manter as marcas de oralidade. Em caso de eventual publicação, o material será revisado.

\section{TRANSCRIÇÃO DE ENTREVISTA A}

Entrevistada: Beatriz Cruz

Entrevistadora: Anna Theresa Kuhl

Duração: 50 minutos

Data: 06/05/2020

Entrevistadora - Olá Beatriz, você pode começar contando um pouco de como as ações de levaram ao Descaracterizar-se, como foi esse processo?

Beatriz Cruz - Comecei a realizar essas ações do Desandar ${ }^{73}$, me lembro de uma vez em que estava fazendo uma outra coisa, outro trabalho, com um coletivo que estava no fomento à dança, eram uns encontros para estudar textos sobre gênero, propus que as pessoas levassem peças que elas trocassem com outros gêneros.

Esse processo fazia parte de uma peça, me lembro que eu peguei uma coisa de um amigo, depois uma coisa de uma amiga, então foi me dando a ideia de realmente concretizar isso do Descaracterizar-se.

Logo pensei assim que seria interessante começar com minha mãe, que foi a pessoa que primeiro me vestiu. Durante o Descaracterizar-se, com algumas pessoas e sobretudo as que tem filhos, vinha muito essa reflexão que nos primeiros anos de vida, durante algum tempo, você é vestido. $O$ que isso provoca em você? Foi quando pensei em começar com a minha mãe, naquele momento ainda era meio que um teste, vamos dizer, estabeleci algumas premissas: seria uma semana porque também eu sentia que era uma coisa que você precisa viver, você precisa que aquilo de alguma maneira decante no teu corpo para que

\footnotetext{
${ }^{73} \mathrm{O}$ projeto de performances onde está inserido o programa de Descaracterizar-se.
} 
as percepções venham, sabe? Percepções e transformações. Então eu estabeleci isso, eu pensei que cada uma das pessoas, eu e a outra pessoa, iam ter cadernos e que depois a pessoa me dava isso. Eu queria fazer um pouco inspirada pela Eleonora Fabião, algo que uma pessoa que indica a outra que indica a outra que indica a outra, e por aí vai.

Comecei, a primeira semana com a minha mãe, que indicou a minha irmã, minha irmã indicou minha prima, minha prima indicou minha vó, minha vó indicou minha outra prima. Isso era muito natural, mas ao mesmo tempo eu me mantive ali nas pessoas da família. Minha prima estava um pouco com dificuldade de encontrar uma pessoa aí ela mesma pensou em indicar a Ju. Então pensei em começar pela Ju, uma outra linha, que seria minha amiga mais antiga. Aí ela me indicou uma outra pessoa que eu não conhecia, foi a primeira pessoa que eu não conhecia, só de vista e tal, e foi super né, a pessoa era bem diferente, conectada com questões de moda, só que era inverno, e foi um inverno super frio, e ela não conseguiu ninguém para indicar. Ao mesmo tempo, tinha acontecido alguma coisa também na minha vida, não lembro exatamente, mas eu parei. Vou parar um tempo para organizar direito, preciso fazer isso funcionar, isso das pessoas não conseguirem indicar, sabe? Das pessoas não quererem participar, mais uma semana com a roupa, sei lá, eu senti que tinha uma dificuldade, tiveram duas pessoas com dificuldade e as outras indicaram pessoas muito próximas. Comecei a pensar, estou realizando isso, e aí? Então eu percebi que talvez eu devesse abrir, pra fazer a coisa acontecer, seria interessante que primeiro eu abrisse para um leque maior, de pessoas, que realmente quisessem participar, e que eu não ficasse refém disso, da pessoa não conseguir porque me fazia ter que parar. Ou eu seguia, essa última menina, nossa, eu fiquei umas duas ou três semanas com as roupas dela então eu abri, foi quando abri, fiz o chamamento no facebook, mas meio para as pessoas com quem você já tem acesso, nas suas redes, ainda que tenha um pouco de indicação, e isso começou a rolar. Fiz essa chamada, criei o instagram e pensei, vou postar todo dia. Porque durante esse teste eu entendi algumas coisas, sempre fazia uma foto do mesmo ângulo e tal. Isso do instagram também ia me ajudar a escrever, porque o caderno é isso, às vezes, escrever todo dia num caderno pesa muito mais que no celular, numa rede social. Quando tem isso do outro também estar vendo, estar 
interagindo, me ajudava a pensar sobre. Acho que essa questão da roupa, tem muito isso, tem muito a ver com como os outros te veem.

E essa percepção, esse grau de reflexão, era importante também pra mim. Então quando eu publicito isso, eu consigo ter esse retorno do outro, essa reação das outras pessoas, de uma maneira mais fácil. $E$ eu acho que isso é importante na experiência como um todo.

E aí foram vindo as pessoas. Meio natural, meio não parou, as vezes a pessoa falava "posso te indicar para um amigo?" então eu ia, em determinado momento comecei a pedir para as pessoas que já tinham participado indicarem e era legal porque o compromisso não era elas indicarem logo para ser o próximo, daí elas já iam falando, articulando, aí começavam a vir pessoas que eu não conhecia, sabe assim, demorava um tempo para as pessoas virem, eu tinha um cronograma e isso fez a experiência fluir, porque ela (a performance) tinha isso né, uma questão temporal importante que eram os 7 dias, e que eu não queria parar, eu queria fazer continuamente. Quando eu comecei eu não tinha ideia de quanto tempo eu ia fazer. E no começo era sempre assim "ah vou fazer mais um mês, aí mais um mês" até que de repente eu decidi - só vou parar quando fizer um ano. E esse vai ser o tempo. Não era algo que eu comecei e já sabia.

Mas é que aí eu comecei a entrar em contato com trabalhos de outros performers, que já tinham feito isso, não exatamente isso, mas de performances mais longas, então achei que pra mim isso seria mais relevante. E que eu ia conseguir ter percepções mais interessantes. $E$ de fato ia colocar meu corpo num processo duradouro. E aí foi.

E. - No seu repertório de trabalho artístico anterior, havia preocupação com o traje?

Beatriz Cruz - Ah eu nunca tive, nunca foi um suporte que eu criasse muito em cima, nas peças sempre tinha algum figurinista, criação coletiva, existia diálogo, e como performer eu acho que nunca foi o centro da minha atenção, no processo criativo era a última coisa que eu ia pensar. Tanto que acho que na performance, principalmente porque eu comecei nessas questões do caminhar, tem algo muito forte sobre a roupa do cotidiano. E de alguma maneira, essa roupa do cotidiano, 
meio diferente, meio estranho assim, quase como se quando eu passei a performar, eu passei a viver com a roupa da performance também, tanto que eu usava muito, e uso até hoje, é que agora a gente tá nesse momento bizarro, eu tenho um colete, que eu comecei a usar porque comecei a fazer muita caminhada na cidade, fazer muita intervenção, então em determinado momento esse acessório que não é uma mochila mas é algo mais prático e guarda as coisas que the serão necessárias, de repente eu estava indo para todos os lugares com ele. Não é que ele era um acessório para performance, sabe assim, é uma coisa que foi meio de mão dupla e foi um acessório que me caracterizou durante muito tempo e sei que tem pessoas que me conheceram justamente nesse momento e que falavam "isso é a sua marca, você está sempre com coletinho" tanto que depois eu comecei a usar em festa e aquilo virou meu eu, para ir a todos os lugares eu até queria ter, na época eu devia ter tido um coletinho de festa, mais arrumadinho.

E. - E como foi estar descaracterizada no seu cotidiano, dando aulas e fazendo produção, sem seu colete super cheio de utilidade?

Beatriz Cruz - Ah, era super difícil. Era bem ... ah essa coisa do que você faz, não trabalho sempre com produção, então tenho momentos de intermitência, às vezes estou em um projeto, às vezes não, mas eu me lembro muito bem, até descrevi isso outro dia, que eu estava conversando com a minha prima, sobre quando estava sendo vestida pelo Rodrigo, homem cis hetero, ele tem uma roupa de menino clássico, calça jeans, camisa e jaqueta (estava frio), tudo um pouco mais larguinho, ele tem um cabelinho mais pra trás, então eu punha o meu cabelo bem pra trás assim e ia. Nesse momento, eu estava fazendo uma produção grande de um grupo de Portugal que estava no Brasil, e foi muito difícil. Eu fiz a produção prévia, eu tava vestida de Rodrigo, então teve uma vez que fui pedir apoio num restaurante, e tinha uma questão do gênero muito forte. Uma coisa é - eu era uma mulher, vestida como um homem, performando o que é dito masculino, e pouco sedimentado no meu corpo aquilo. E eu uso do que é dito feminilidade, do que é ensinado pra gente, totalmente pra fazer produção, ainda mais para conseguir um apoio. E eu não conseguia falar. Lembro que fiquei sem palavras, não conseguia me encontrar ali, o cara olhando pra minha cara ali. Falei meio aos trancos e barrancos, obviamente não consegui o apoio, e aí 
isso foi meio sério, nesse período decidi que ia só ligar pros lugares. Na semana seguinte, outra etapa da produção, eu estava com a Talita, que era um outro oposto, batom o tempo inteiro, me lembro até de um espanto das pessoas, nesse trabalho (do grupo de Portugal), fiquei com eles uma semana, então eles me conheceram como ela, Talita, e logo no começo, como eu não conhecia ninguém, não sabiam que eu estava fazendo isso, isso era legal "você é assim" o Marco, que era quem tinha me chamado, até falou "nossa, gostei desse seu novo visual", eu não falei nada pra ele, não vou falar, deixa, eu também tava achando interessante estar nesse outro lugar, e também acho que acessa outras coisas, então eu ia lidando, tô tentando lembrar se algo me fez não usar a roupa da pessoa, mas eu acho que não.

Teve uma vez, eu ia voltar tarde do Itaim Paulista e ela (a pessoa) tinha falado para eu usar um shorts bem curto e um coturno e aí eu não fui, eu usei outra roupa dela. Porque as pessoas iam me falando, variava muito, mas no começo eu pedia indicações, ah eu tô indo pra tal coisa, eu fazia um encontro com as pessoas e era bem importante esse encontro, as vezes as pessoas já falavam muito sobre elas e o que usavam em determinadas ocasiões ou não, ou elas falavam, ah pra mim o critério é muito mais sobre como estou me sentindo ou do que onde vou, é eu queria ficar andando só assim mas vou pensando o que que eu faço. Então esse critério que as pessoas ficavam me falando era bem importante, porque era o que guiava as minhas escolhas durante a semana, com muitas pessoas eu perguntava às vezes eu trocava ideia no whatsapp, "hoje eu vou em tal lugar, ponho essa ou essa?".

E. - Como você fazia com tamanhos muito diferentes do seu corpo?

Beatriz Cruz - Eu acho que sapato é das coisas mais importantes, eu pedia, mas muitos eu não conseguia usar porque eram muito grandes. Os que eu conseguia usar eu usava, dava um tempo, entendia um pouco do olhar da pessoa, o que isso alterava no meu corpo e tal, aí as vezes começava a doer, não o pé, mas a coluna, o joelho, e aí eu parava. E quando eu não conseguia vestir, eu tentava entender "a pessoa usa mais tênis", aí eu punha um tênis, a pessoa usa mais mocassim... Geralmente eu não conseguia vestir o dos homens grandes, teve 
uma ou outra mulher que não deixou sapato, eu ia substituindo com coisas que eu tinha que fossem equivalentes esteticamente.

E. - Como era a questão das subjetividades para você?

Beatriz Cruz - Eu acho que já tava um pouco pesquisando e pensando sobre isso, na pós, sobretudo textos da Suely Rolnick, mas acho que foi ficando mais claro pra mim conforme eu ia experimentando, o que seriam essas transformações na prática. Tem também uma outra referência que eu sempre usei que foi a Rosane Preciosa, ela também fala muito disso. E o que eu logo percebi é que a gente constrói uma coisa independente se a gente para pra pensar "ah eu vou construir", acho que não é assim, não acho que é uma coisa tão racional assim, mas de alguma maneira a gente vai construindo essa imagem, esse jeito de ser que interage, a coisa das roupas que a gente põe os adereços como a gente se mostra, e ela estabelece o seu modo de ser, aí a gente constrói isso, é só uma possibilidade, entre muitas. Era muito interessante quando eu vestia e a pessoa se via, aquele negócio que a gente tá tão apegado talvez da imagem ou de quem a gente é, é meio que só uma possibilidade, e isso foi muito interessante porque de alguma maneira, foi me fazendo mudar várias coisinhas em mim, coisas práticas, óbvio, quando eu voltei, deixei de usar, era meio "o que eu vou usar", comecei a fazer coisas muito diferentes, e também coisas muito iguais, porque eu sentia falta.

Num determinado momento da experiencia, aos três ou quatro meses, algumas pessoas aceitaram também começar a serem vestidas, então naquela semana eu dava as roupas e eu via que cada vez mais eu entregava as roupas e já tinha um discurso pronto - olha, eu usava assim, mas agora, eu usaria isso com isso. Eu costumava usar assim, mas agora, eu usaria assado, ou, por exemplo, eu fiquei com uma peça de roupa de uma pessoa, porque ela que achou "ah parecia tão sua" .

E. - Em algum momento, te parece que as trocas traziam memórias físicas a você?

Beatriz Cruz - Quando você tem roupas que vem carregadas de uma memória forte, e as vezes é uma memória besta, do lugar onde você estava quando você 
comprou, ou quem te deu, ou o que ela passou, e essas coisas consigo acessar algumas, mas não tudo. Quando você coloca uma roupa que já usou várias vezes você tem esse sentimento, em determinado momento, as pessoas tentavam falar um pouco disso, eu via que isso era super importante. Às vezes isso também pautava, quem que deu, "ah quando que eu ia usar", porque é um pouco parecido com uma relação que fazemos e eu fui percebendo isso também nas minhas roupas, também tinha isso, o que eu escolhia, e desse uso afetivo que passava por essas memórias. De alguma maneira, e aí não tenho tanta base pra explicar, acho que existe uma questão que é uma memória meio energética, as religiões orientais falam muito disso, essa coisa da roupa de quem morreu, ou de como as energias corporais ficam na roupa, se a gente pensar que colocamos um monte de tecido e outros materiais sobre a nossa pele e que a pele é nosso principal órgão do sentido, isso é bem importante e acho que não consigo analisar tão racionalmente, nunca fui muito a fundo nisso e talvez devesse ir. Os pequenos relatos dão conta de alguma maneira porque se você os lê na íntegra, você consegue acompanhar essa flutuação de sensações e estados e eu acho que isso é importante. Tem uma mudança que é corporal também, é que agora não estou falando da memória, estou fazendo uma digressão porque no momento em que me lembro que descobri que as minhas anotações, normalmente, de cada pessoa, elas começavam com aspectos físicos muito fortes, e aspectos concretos, então quando eu buscava conectar vários aprendizados de corpo, tentar perceber micro alterações, acho que isso foi importante, porque era um jeito que eu ia entrando naquela roupa e ia percebendo se tem muitos decotes de tal maneira, se os tecidos são mais pesados ou mais leves, o que isso muda no meu ombro, é, o que que um sapato altera na coluna, ou a recorrência de uma peça, se a pessoa usa muito saia longa, roupa larga, roupa, claro, isso também tem a ver com como essa roupa chega no meu corpo. Esses nuances físicos sempre tem nos relatos, sempre tem. Sempre parto disso.

Em alguns momentos senti que fiquei bem emocionada com essa forma de presença e que era algo que racionalmente não consigo explicar, acho que os relatos dão mais conta porque têm uma escrita mais poética, isso era uma sensação muito forte da presença da pessoa. Pensando numa questão mais 
ligada ao teatro e performance, pra mim toda essa experimentação é muito física, eu tava o tempo todo com a minha presença muito ativada e isso vai trazendo uma sensibilidade, uma presença, mesmo porque tenho que me adequar para carregar essa roupa e continuar fazendo todas as coisas que eu faço, me exige uma presença de percepção mesmo, de entender que era preciso decodificar tudo isso de uma forma rápida, o que exigia uma presença física muito forte.

E. - E sobre elementos externos, como as próteses ou a boneca, na troca com a mãe, como isso se refletia na presença para você ?

Beatriz Cruz - A pessoa da prótese é a Estela Lapponi, ela teve um AVC que paralisou essa parte do corpo, então ela usa muitas vezes uma tala, que ela me deu para usar e é uma coisa que se você tem sua mão direita impedida, me lembro que estava escrevendo e era muito difícil, não é que eu não tinha movimento, mas existe uma conexão. Me lembro que estava escrevendo uma monografia e a conexão da minha mão com a cabeça não funcionava. Nesse momento eu tirei inclusive foi uma das que eu tirei porque eu não conseguia avançar no texto porque aquilo estava me travando tanto que nos momentos que eu queria escrever eu tirava.

E. - E com relação a boné?

Beatriz Cruz - Ela brincou "porque tenho um bebê, fico com ele a maior parte do tempo, então vou te dar essa boneca só para você lembrar que tudo que eu faria eu faria com o meu bebê, porque não tenho quem fique com ele", então tive essa presença dela, acabei não andando tanto com boneca como bebê, mas estava sempre comigo, eu punha na bolsa...

E. - E sobre as suas referencias com a performance, o que foi importante para você?

Beatriz Cruz - Comecei com Eleonora Fabião, foi muito importante, quando começamos a estudar performance. Outros vão situar em um contexto de performance mais amplo, essa diferença com a performance arte, talvez eu esteja mais nesse sentido, de performance arte, mais ligada nessa arte do fazer, da ação, e não dessa outra maneira de entender a performance, quando colocamos tudo dentro desse guarda-chuva, que eu acho que está mais na linha 
do Schechner, então comecei a entrar muito mais em contato com a Eleonora, com o que depois ela vai sistematizar naquele "livro amarelo", foi super importante pra mim o contato com pessoas próximas fazendo. Eu vinha do caminhar - todo esse estudo do caminhar, que a gente se propunha no coletivo Dodecafônico, falo que foi isso que abriu o campo da performance pra mim. Eu vinha do teatro, um teatro que a gente fazia na rua, que até a gente falava que não era um teatro de rua, não é quando você monta um teatro na rua, pode ser arena, mas sabe, a gente fazia na rua, interagia com diferentes ambientes da cidade, e então fomos para uma coisa da intervenção urbana, que já é performance, mesmo depois a gente estudando Tó (Antonio Araújo), várias das ações que a gente fazia, ele chamava de performance urbana, e não de intervenção urbana. Intervenção urbana é algo que muita gente fala que se refere a intervenções físicas, como arte urbana, grafite, lambe-lambe, isso seria 0 conceito geral. Mas acho que esses nomes eles estão na fronteira também. $E$ a gente sempre chamou o que a gente fazia de intervenção urbana e começamos a pesquisar a cidade, no Dodecafônico, e aí chegamos nas questões do caminhar, então nos situacionistas, que propunham deriva, e tinha a Paola Berenstein Jacques (arquiteta) lá da Bahia, que já estava estudando isso a muito tempo, e também estudando muitos artistas brasileiros, essas questões da cidade, ela trazia muito essa perspectiva dos flanêurs, na Europa, enquanto você tinha aqui no brasil, em São Paulo, por exemplo, o João do Rio, que estava também propondo caminhadas urbanas, depois quando tiveram os surrealistas também teve movimento aqui, situacionistas também, ela traz o Hélio Oiticica, todos esses são artistas mais ligados as artes visuais ou a literatura, a questão do caminhar sempre esteve ligada a muitos campos - arte, filosofia, arquitetura; sempre inspirou artistas, só que muitas vezes muito mais nas artes visuais. $O$ caminhar é um processo para se gerar um tipo de obra. Estávamos vindo do teatro e como que era isso? Começamos a pesquisar o caminhar como pratica estética, entendendo que também é política, que essas coisas não são separadas, só que a coisa em si tomou uma proporção que o caminhar em si já era a ação, eu não estou fazendo isso para criar um outro produto artístico, para se criar uma outra obra, o caminhar em si já é uma obra. Então por exemplo, fizemos a travessia da cidade de são Paulo, atravessamos de leste a oeste, foram 2 dias andando, isso é a obra, isso é em si um ato performativo e 
performático. Ok, mas como eu relato essa experiencia? Com o Coletivo Dodecafônico (como porta de entrada) comecei a vislumbrar essas fronteiras, essas questões, onde está a performance, onde está o relato da performance, o que é a obra.

Aí que digo que o projeto Desandar, onde o Descaracterizar-se está dentro, veio dessa história. Bom, podemos puxar conceitos de performance para falar do Descaracterizar-se em si. Como eu andava muito na cidade, eu andava muito para dentro, nessas muitas camadas onde construímos a nossa subjetividade. Constrói, desconstrói, reconstrói. Então acho que essa foi uma grande referência, sabe? Esse pesquisar do caminhar, na performance.

Fui entrando em contato com um monte de artistas, nesse momento também, comecei a fazer parte de uma estação colaborativa que era o La Plataformance , e aí tinha muitos artistas da performance mesmo, pessoas que já estavam trabalhando com isso há muito tempo, então também digo que não é uma referência teórica, mas é uma referência de ver pessoas atuando, ver diferentes formas de fazer, nesse mesmo tempo conheço o livro amarelo da Fabião, o trabalho da Yoko Ono, (isso eu citei), o livro, a Linda Montano com Art Life Institute, acho que esse foi o meu caldo maior (entrar em contato com trabalhos de outros performers), aí comecei a me interessar por gênero, conheci o Paul Preciado... Referências todas brancas, do norte, tirando a Eleonora Fabião e os artistas brasileiros que eu estava conhecendo, comecei a buscar outros performers que fossem latino americanas, e outras que me inspiraram muito foram a Ana Mendieta, que é cubana, Regina José Galindo, que é guatemalteca... Mendieta, pelas formas que ela propunha, tanto é que ela tinha aquele trabalho que ela pegava seus pelos pubianos e transformava em barba e bigode, a primeira vez que eu imaginava o Descaracterizar-se como trocar de roupas com um amigo, um homem, e aí ele me passar os pelos dele, sabe assim, lembro que lá no começo até redigi, junto com outras mulheres do Dodecafônico, essa proposta de troca de pelos, mas isso nunca aconteceu.

Já a Regina José Galindo, que estaria aqui no FIT, comecei a me interessar muito pela forma como ela escreve e relata os programas dela, bem forte, sucinto e poético. 
E. - E sobre o uniforme ... como te parece a questão da invisibilidade?

Beatriz Cruz - Tiveram duas pessoas, uma que foi a primeira, atendente de farmácia, o namorado a indicou, ele já havia participado, ela é da zona leste, e era muito gritante a diferença das roupas dela e do kit uniforme. Ela me emprestou, esta, de fato, eu usei, acho que dessa eu consigo falar mais. Foi bem impactante a troca com ela. Tanto por eu ter usado, mas sobretudo pelos relatos dela. Ela me deu um dos uniformes para a performance, o outro ela estava usando, mas deu trocas de roupa que ela usa quando não está trabalhando, "uso pouco, porque passo muito tempo trabalhando". Aí coloquei, você veste aquilo mas ao mesmo tempo está fazendo todas as outras coisas, então é "porque você está com isso?" em um momento que eu não deveria estar usando, por mais que eu estivesse fazendo esses dois trabalhos, sempre teve um olhar de estranhamento, acho que também tem uma identificação logo de cara com outras pessoas que também estão usando uniforme, então se você reparar bem, é que as vezes a gente tá tão atarantado que passa despercebido, mas tem muita gente de uniforme no metrô, é que a gente não percebe, comecei a perceber que tinha isso de levar e se trocar no local de trabalho, uma vez no lugar, vestia lá. Então essa coisa da prática e tal, só que assim, nunca estive no ambiente desta pessoa trabalhando, então eu não tinha toda a questão da invisibilidade que o uniforme dá, não tenho essa experiencia. $O$ fato de eu usar aquilo é simplesmente eu perceber essa uniformização e você ter que estar muito tempo da sua vida igual, da mesma maneira, com a mesma cor, o mesmo tecido, as vezes é um tecido que não te agrada e tal, mas também tinha o como você tem que estar com esta roupa, você tem que estar maquiada, com a unha cortada e feita, você tem que estar com o cabelo preso, isso eu acho mais forte do que aquilo que o uniforme traz, porque não é só a roupa né, é um modo de agir, e ele é um modo de se apresentar. E acho que isso impacta demais o corpo. De novo, cheguei a experimentar essa diferença unpassant, porque ela também me deu as roupas dela, as roupas que ela gosta de usar, e ela tinha todo um estilo, coisas muito próprias, um negócio de cabelo que ela pendurava, brincos de pena, um monte de coisa de pena, umas saias longas, um visual bem assim, não exatamente comum, tipo calça jeans e camiseta, não, era um visual de alguém que gosta de pensar sobre isso, que curte isso. Que num certo sentido 
está um pouco fora do padrão. Isso foi impactante. (...) depois de um tempo da troca, ela foi ver a exposição. Nesse momento eu ficava lá, durante alguns dias, oferecia de trocar de roupa ali, o Descaracterizar-se Café, fazíamos uma foto, tomávamos um café junto, e conversávamos sobre aquilo. E ela foi de novo, estava muito diferente, e conversamos muito.

Com a Alda foi um pouco parecido, para completar essa reflexão do uniforme, vem muito a questão do traje dentro do ambiente da penitenciária, onde também trabalho, desde 2016, faço um trabalho lá, na penitenciária feminina da capital, onde trabalhamos com várias linguagens, artes visuais, performance, teatro, cartas; e justamente o trabalho de performance, porque tem isso do uniforme muito certo, tem até uma escrita minha que até está no texto da exposição, "quando querem te doutrinar, te formatar, interferem nessa roupa", seja o que você vai vestir, colocando um uniforme, ou como você tem que se despir. Eu havia feito essa reflexão, tanto na prisão te colocam um uniforme, mas fora dela também é isso, a gente não pode escolher mostrar nosso corpo, no instagram, é sempre bloqueado, lá (no presídio) pedimos autorização para trabalhar com roupas, entrávamos sempre com uma mala de roupas, de todos os tipos, eram muitas peças de roupa, uma mala gigante. E a primeira coisa é que elas podiam se trocar ao invés de ficar com o uniforme, durante a oficina de performance. Ílamos criando figuras, imagens, histórias, cenas, com aquelas figuras. Também foi uma experiencia importante, e muito diferente, isso da padronização do uniforme, a questão do corpo sempre no mesmo modelo, mesma cor, e claro, mas sempre, as subjetividades aparecem. Sempre encontram um jeito, quase como uma infiltração, se não pode na roupa, será no cabelo, se não pode no cabelo, será no olho, então quais são os caminhos que você encontra para ir contando isso.

E. - Te parece que existe uma coisa do gênero, do feminino ter que pensar mais nas escolhas das roupas?

Beatriz Cruz - Não acho, em algum momento senti que as coisas eram mais ou menos parecidas, no fundo, o que é da performatividade feminina tem mais opção, das mulheres, do que é entendido como feminino, ele normalmente, eu não sei, senti que você tem muito mais coisas ou opções, mas essa coisa do 
vestir pro outro, não acho. Até porque era o mesmo jeito, tudo tinha essa percepção do outro, mas o que eu tenho é que é um conjunto de coisas muito maior, um conjunto de variedades, tipos de roupa, tipologias. Também tiveram uns caras que eram super "olha isso, isso aqui", não consigo fazer uma análise, um recorte, relembrar se foi isso ou não, porque agora de cara eu acharia que não, que não teve, até porque acho que todo mundo que estava se envolvendo também tinha esse desejo de falar, de ter criado um discurso sobre si, porque estou escolhendo essas roupas, quais roupas são, tanto homens quanto mulheres, acho que minha percepção é meio prática, porque o que tem disponível para a performatividade feminina é mais complexa, a gente tem muito mais para vestir, saia, calça, meia calça, cintinhos, não-sei-oquezinhos, brinco, nananã, os homens tem menos adereços.

E. - E sobre a impressão de que o outro está performando, se a pessoa está pensando mais do pensaria normalmente?

Beatriz Cruz - Acho que sim, normalmente você pensa, mas não sei se ele está performando, se entra dentro daquelas coisas todas, mas ele está fazendo uma escolha, tem pessoas que me falaram isso, que demoraram, justamente porque estavam inseguras sobre este momento, de definir, ah o que eu escolho, como que é e tal, o momento em que a pessoa passa as roupas.

Eu acho que as pessoas pensavam a maneira como elas tinham que se mostrar, eu não consigo avaliar, isso é muito subjetivo, mas que havia um pensamento, sobre como vou me mostrar e o que vou escolher, não tenho dúvidas, mas também não acho que as pessoas criavam coisas que não fossem reais sobre a vida delas, talvez elas misturassem coisas e algumas pessoas verbalizaram isso, "tem coisas que eu visto, mas também estou te dando peças que eu comprei, consegui adquirir, mas não uso muito, mas que eu gostaria de usar, e por uma série de razões eu não usava”. Isso aconteceu algumas vezes e foi sinalizado, as pessoas disseram "isso é o que eu uso, isso é o que eu sou, mas isso é o que eu gostaria de usar, se eu pudesse, eu usava só isso". Uma das pessoas que falou isso foi a Juliana, se pudesse a roupa que ela usaria todo dia era uma calça de moletom e uma camiseta vermelha, tem duas Julianas, o engraçado é que as duas falaram isso, (uma está no instagram, a outra não) vou te dar essa blusa 
que por algum motivo não consigo me desfazer. Então aí tem essa coisa do desejo e tal.

Tem muito que as pessoas colocavam das histórias, porque que elas escolheram, teve o Márcio né, ele foi mais no começo, ele escreveu uma coisa muito interessante onde ele falava, será que o fato de eu ser tão desencanado não é justamente uma escolha? Ele tem um visual punk, ele como performer é o espunk-me, então tudo é bastante performático, tem essa questão da performatividade forte, e a escolha dele foi muito precisa, escolhi essa blusa porque ela $\mathrm{x}$, tinham coisas muito profundas sobre cada coisa, sobre cada escolha, uma história das peças, e vinha com muita camiseta de banda, camisetas históricas, então essa camiseta eu tenho desde tanto, ainda que o visual quando você vê na rua poderia parecer super desencanado, na verdade não era, nunca é.

E. - O que vc mais lembra das trocas, o que mais te afetou?

Beatriz Cruz - Pessoas muito próximas me afetavam e pessoas que traziam um referencial muito diferente também me afetaram muito.

Túlio, eu também vesti ele, acho que já te falei, e ele tem uma pesquisa sobre roupas, ele se veste com roupas ditas mais femininas, foi uma troca bastante intensa, ele escreveu bastante e tal; a Beatriz Barjud, as pessoas comentavam muito; outra que me lembro muito, até pela diferença, foi a Aloá, ela me deu uma mala gigante, tinha coisas muito especificas, era muito diferente de mim; a Sandra me afetou muito por causa da proximidade que a gente tem, como também, nessa proximidade, tinha uma transmutação muito grande, até me lembro que uma vez o marido dela me viu vestida dela e até me confundiu, teve um dado emocional muito forte; o Pedro Galiza, que é o filho da Alda, ele tem um estilo de cortar as roupas, e ele é não binário trans, não sei agora como ele está se definindo, foi o primeiro que de fato cortou o meu cabelo, o Roberto também, porque fiquei muito tempo com ele, também era bem intensa a troca com ele; nossa o Plínio, teve uma coisa toda de envolvimento familiar, eu lembro que ele tinha uma filha pequena que estava super ansiosa para ver "ai eu quero ver você de meu pai" e também foi super gostoso porque tinha essa outra interlocução. 


\section{Apêndice B}

Nota: neste apêndice entrevista optei por manter as marcas de oralidade. Em caso de eventual publicação, o material será revisado.

\section{TRANSCRIÇÃO DE ENTREVISTA}

Entrevistada: Verônica Fabrini Machado de Almeida

Entrevistadora: Anna Theresa Kühl

Duração: 30 minutos

Data: $26 / 06 / 2020$

Entrevistadora: Oi Verônica, muito obrigada por ter topado essa conversa! Separei questões sobre a peça Como se Fosse, onde fui figurinista e você a diretora. Essa é a peça mais recente do Grupo Matula Teatro, em que as atrizes são suas parceiras de longa data... O que você pode me dizer sobre esse processo, suas primeiras impressões e pensamentos sobre como deveria ser 0 figurino para que funcionasse na encenação?

Verônica Fabrini - As primeiras impressões, logo no início do processo, pegando a peça, até mesmo para decidir os tipos de ações que essas personagens fariam, e a partir das ações, os objetos que seriam interessantes elas terem, sempre existe essa angústia dos atores com o texto, o que é que estou fazendo nessa hora, e as ações sempre vão apoiar, construindo uma linha mais sólida de caminho. Então, me parece que a imagem principal, e a primeira imagem que nos veio foi a questão da costura, e essa costura, e essa questão de um universo arquetipicamente feminino, que você vai puxando a partir da ideia do costurar. Desde as moiras, que tecem fio e cortam, até sei lá, Penélope, e já caminhando até para esse universo feminino e feminista, que a peça, o texto vão abordar... Ficou na minha cabeça, muito um "grande tecido" da peça, basicamente essas duas figuras, muito das Moiras, essa ideia das tecelãs... Bom, caminhando por aí, na questão do destino, por causa de como é que primeiro você tece, constrói, das tecelãs, e depois corta, essa ideia também, que era chave da peça, que conta a história de uma costureira, que vai ser 
assassinada com sua própria tesoura. Então isso é muito forte, a essência, se fosse resumir, é a história de uma costureira que é morta pelo marido, que usa o próprio instrumento de trabalho dela, então a partir daí você já tem um monte de contradições, de aflições, e já vai trazendo todo um universo para as ações. A questão da máquina de costura, que eu acho que é uma coisa que não sei, eu tenho muito isso de memória, do quarto de costura das minhas tias, o quarto de costura da minha avó, e aí puxando um pouco pra relação da mãe e da filha, a história é muito isso, do jogo da mãe com a filha, até imagino que esta seja uma memória bastante comum feminina, o quarto de costura da vó, eu não sei se, da minha geração é mais, mas isso era uma coisa que sempre me marcava, então o próprio barulho da máquina de costura, e aí todo esse mistério do molde, que até depois quando a gente estava conversando sobre o cartaz, que o molde já chama a ideia da tesoura, então, que muito dos improvisos das meninas foi costurado - olha lá - dentro dessas imagens. Já desdobrando para outro momento, também dentro desse universo arquetípico bem feminino que a gente tem no imaginário que é diz respeito a lavar e estender roupa, isso do varal, essa coisa do cuidado. Do cuidado com a casa, do cuidado com as coisas. Então, todas essas imagens, de molde, tecido, pano, linhas, tesoura, fita métrica, e aí tem toda uma coisa com os manequins também, que a gente pensou e depois foram virando esses duplos da personagem, na primeira cena ela está sendo cobrada de uma roupa que não está pronta ainda ... Então os objetos e os entornos profissionais foram apoiando. Claro, tem a filha, mas a personagem chave, quem sofre o pathos da história, o desfecho, é mesmo a mãe. Essa coisa da costureira pra mim é muito chave na peça. As meninas (as atrizes) já tinham um pouco na cabeça, até mesmo por conta de tudo que vem acontecendo, toda essa imensa seleção que elas vieram fazendo desde o início do trabalho, das seleções dos feminicídios, então é claro que a cor do lilás ao roxo, como cor do movimento (NI UMA A MENOS ${ }^{74}$ ) era uma coisa que estava bastante presente, em termos de, não digo nem em paleta de cores, mas de atmosfera mesmo, do roxo que tem muito a ver com a questão do feminino arquetipicamente, essa cor

$74 \mathrm{O}$ coletivo Ni una menos iniciou sua formação em março de 2015 na Argentina e depois com ações por toda a América Latina, reivindicando a promoção de políticas públicas (leis, projetos, destino de verbas públicas) para mulheres. Disponível em https://www.scielo.br/scielo.php?script=sci arttext\&pid=S1984-63982019000400801. Acesso em 28/02/2021. 
que tanto remete a, tem uma parte meio sangue, uma parte órgão sexual, tonalidades que acho bonitas, que são quentes, são uterinas, eu acho bem interessante. Essas coisas do barulho da tesoura cortando, da máquina, isso da repetição, do trabalho, a mulher está trabalhando o tempo inteiro, está costurando, lavando roupa, isso que a Silvia Federeci vai colocar lá no Calibã e a Bruxa (o livro), esse negócio de você estar sempre cuidando, esse outro livro ponto zero da revolução, que ela vai falar dos famosos trabalhos domésticos não remunerados. A personagem fica entre as duas coisas, entre a costura pra fora e o serviço doméstico, a filha também, quando ela vai, esse lance do arrumar a casa, e daí acho que foram mais ou menos essas imagens que foram emoldurando. Como é uma peça curta, com esses dois planos da filha e da mãe, o da mãe ele é super eixo, então foi relativamente simples, num primeiro momento, pensar nisso. Como a proposta do grupo não era só a peça mas também esse jogo com a questão dos feminicídios, então também passava de uma história pessoal para uma história social, um drama coletivo, pensamos como fazer essa passagem, como trabalhar a questão dos depoimentos, e aí essas imagens todas que foram nascendo a partir da ideia do varal, mesmo, tem essas camadas, até o próprio fio do varal, aquele momento que a gente corta e tal, foi bem inspirado, jogando com esse arquetípico das Moiras e com o concreto das meninas, então essas ideias dão início a essa conversa. Tem outra coisa que acho que é sutil e super bonita no texto, o dedal, o dedal é uma proteção tão delicada, quase que uma metonímia do assassinato com a tesoura, é uma coisa boba, simples, mas que é uma ação concreta da peça, ela procura esse dedal, ela perdeu essa proteção, tem isso do micro ferimento, dessa micro injúria, como isso expõe ela a essa injúria maior, então pensando nessas duas camadas, a proposta das meninas do Matula, que era ir pro jogo, muito concreta, dos feminicídios da cidade de Campinas, pensando aqui como que depois isso veio a tomar forma com os bordados, com os nomes nas roupas, que eu achei muito lindo, muito delicado. Faço esse parênteses sobre minha amiga Claudia Echenique, diretora de teatro chilena, bordadeira, ela fez um projeto que depois foi em presídios, um monte de coisas, com os desenhos da Violeta Parra, ela bordou todos num manto, e esse manto cobriu as pessoas para elas verem umas peças nuns lambe-lambes pequenininhos. Tem um dito chileno que fala (Claudia alegava ser chileno) "cada punto una sanácion" - cada ponto uma cura, então 
esse ato antigo de você bordar quase como parte de uma meditação, então acho que os nomes das pessoas bordadas nas roupas elas vão adquirindo uma qualidade quase de elementos mágicos e ao você bordar os aqueles nomes nas roupas, podemos olhar como ao mesmo tempo uma mortalha e uma homenagem, e também uma presença, desde aquelas viagens com o nome próprio, que eu acho que é muito forte, não apenas dados ou estatísticas, são pessoas, então acho que essa ideia do bordado dos nomes vai desde a anergia colocada em cada ponto, "uma sanácion", até a própria ideia do nome, acho super bonito essa passagem.

Não tem como não fazer essa conexão, de lembrar de cada caso, de cada história, enquanto você está bordando, acho isso muito forte, muito forte. Então eu achei primorosa essa ação porque envolvia várias camadas, tanto a camada ficcional, mais a camada real, e até mesmo a camada prática, concreta, de construir a cena.

E. - Quando estávamos no processo de construir a cena, havia muito isso da cor, do movimento NI UMA A MENOS, do roxo e do verde, e isso da cor vermelha emergia, eu tentava fugir disso e ela aparecia, quase sem querer, mas eu estava tentando fugir de um significado talvez meio óbvio, isso da morte e do sangue, como você vê isso?

Verônica Fabrini - Sou muito ligada a coisas arquetípicas, e muitas vezes as coisas arquetípicas ficam óbvias, e acho que tem uma força de comunicação muito grande, e vai muito da maneira com que isso dialoga com todo o resto, então claro que se fica no fácil do vermelho, pode cair no estereótipo, no óbvio da coisa, mas querendo ou não, nossa, o vermelho ele evoca muito, quer a gente queira ou não, tem uma parte nossa que não é racional que lê isso, com muita vivacidade, que lê o vermelho, que decodifica o vermelho, se a gente eliminar a camada da razão e for para camadas mais arcaicas, o vermelho ele tem essa potência e que mais até que ligado a todos os sentidos que ele tem, do sangue, da morte que ele tem, estou pensando aqui o vermelho como cor do chakra básico, o vermelho é a cor da encarnação, a própria palavra né, encarnado, ele é a cor do "estou presente no mundo material e por estar presente no mundo material eu estou suscetível ao que nele ocorre", de estar preso nas dimensões 
e espaços temporais da existência corpórea, o vermelho ele está pensando em termos da velocidade da vibração mesmo da própria cor, ele diz e ele nos informa isso num lugar muito pouco racionalizável, então é claro que depois vem as outras camadas todas, mas acho que as outras camadas, que vão estereotipando e talvez levando o vermelho para um lugar comum, não esterilizam essa potência, claro que aí vai da maneira de você trabalhar todo o resto, tô lembrando de um vermelho super da minha geração que é quando o Maurice Dejard, nos anos 1970, ele fez o Bolero de Ravel, primeiro um bailarino depois uma bailarina e ele dançava num círculo vermelho, era só isso, o espaço cenográfico era um corpo sobre um círculo vermelho e aquilo tinha uma força, tanto pelo círculo, e são coisas assim que você pode até reduzir a um clichê, tanto o círculo quanto o vermelho, mas tanto um quanto o outro, uma potência arquetípica de decodificação por outras camadas que não a racional, que não é de se jogar fora. Aí claro, era a maneira com que ele ia desenvolvendo a obra sobre esse vermelho, então aí também acho que tem o lance das meninas (as duas atrizes do Grupo Matula Teatro), como elas vão desenvolvendo sobre isso, e as próprias metamorfoses do vermelho que acontecem, que vão pra esse roxo, que vão pro blackout, mesmo pro rosa, tem todo um caminho aí, que dá um movimento para a cor, não tenho esse "grilo" do vermelho como óbvio, nesse caso, porque tem todo esse caminho.

E. - Talvez tenha ficado também - pensando agora - vermelho embaixo e em cima aquela cor apagada, mas que vai um pouco como uma continuidade da coloração da pele das meninas. Uma leitura possível é apagada em cima e acesa embaixo, você acha que faz sentido dentro da dramaturgia, não faz...

Verônica Fabrini - Acho que faz bastante sentido, pensando até nessa relação que eu estava falando sobre a vibração da cor, é a que nos liga a materialidade, e claro, dentro disso, ela não fica presa aí, ela sobe, ela se evapora, ela se mistura, ela se tinge. Até esse apagado que ela vai ficando, acho bonito, porque ela vai ficando quase que contaminada por um mundo cinzento, que perdeu a vitalidade. Eu estou pensando na vitalidade delas quando tem a coisa da infância, quando elas brincam juntas, da amarelinha, quando elas pulam corda, quando a mãe tá apaixonada pelo pai, quando eles transam e aí esse 
esfumaçar de tudo isso, naquilo que vai ficando meio cinzento, de perder a vitalidade

E. - da vida ir embora, um cadáver é cinza né? E tem a coisa da gola alta...

Verônica Fabrini - Pode emular um certo silenciamento...

E. - E tem isso que mãe e filha são parecidas, a cor é parecida, você acha isso importante como informação visual?

Verônica Fabrini - Daí eu acho que é bem importante, uma das perguntas que o texto faz é sobre a repetição do modelo, então faz muito sentido, não exatamente uma simbiose, não vou dizer que a peça nega a mãe, por exemplo, mãe careta, filha rebelde, ou mesmo que critica. A filha pergunta como é que eles ficavam juntos de novo, você vê pelas ações dela, não repetindo aquele modelo, mas aquele modelo assombra, é o que a peça coloca como questionamento, é muito importante esse link.

E. - Como trabalhamos com o traje social, não havia exatamente duas trocas iguais, e foi escolhido serem ligeiramente diferentes - parecidos, mas não cópia. Então tinha essa dificuldade da cor, mas havia também uma informação cronológica, dos anos 1980, não exatamente super realista, mas algo que a gente olhe e fica tentando localizar de qual tempo é, que não é desse, então pergunto, isso te parece importante, isso da gente reconhecer que é algo de outro tempo, mas se perguntar de qual época?

Verônica Fabrini - Acho que a diferença dos tempos, elas trazem um dado importante que é a continuidade, de que a coisa ainda continua, passa tempo, muda muda muda, o relógio anda, a moda é outra, e a mulher sempre se dando mal. Nesse sentido, acho que é importante, sem preciosismo de ser ou época x ou época y, acho bem importante termos essa dimensão de que poxa, a gente não vai aprender nunca!

E. - É, a gente nota o tempo passando, a pilha de roupa aumentando, e nada muda...

Verônica Fabrini - É, porque nós, e coitadas das meninas, esse ano caprichou, eu lembro quando começamos o trabalho, eu tinha aflição quando eu 
via que chegou mensagem, sabe? Eu sabia que mensagem que era ... e isso de quando chega principalmente no tempo mais contemporâneo e tudo, a peça acaba tendo três tempos, porque tem o tempo da mãe, o tempo da filha e tem o nosso tempo, das notícias, dos nomes bordados. Foi uma das discussões que a gente teve, do celular né, como que a gente usa, que no tempo da filha não necessariamente era um ano de celular, então acho que é legal esse acúmulo, a mesma situação perdurando no tempo, que é uma coisa importante.

E. - Muito legal que nossa conversa abrange questões da produção e do meu texto sobre o traje... Algo bem precioso para o texto é a relação entre o traje social e performatividade. Na peça, em Como se Fosse, vemos alguns momentos performativos, naquele momento inicial, por exemplo, em que a atriz recebe o público, então tenho uma pergunta, se te parece que o traje social ajuda a construir um pouco dessa performatividade? De não ser algo muito solene, de ser algo que a gente usaria na vida real, no cotidiano...

Verônica Fabrini - Certamente, acho que tem isso, de não ser uma roupa muito extraordinária, que permite as personagens serem normais, vamos dizer assim, imagine se a atriz chegasse assim com uma roupa bem conceitual, naquela cena inicial, ou mesmo nos cortes dos fios do varal, podia ser meio engraçado, não é que ia ser meio engraçado, mas o fato do figurino, ele permite você tanto estar presente na ficção, por conta da harmonia deles com o cenário, ou com a característica das personagens, mas ele também permite você sair da ficção sem causar um degrau muito grande, e eu acho isso legal, não causar um degrau muito grande. No caso dessa peça, por causa até mesmo talvez da presença cotidiana, dos feminicídios, é legal não causar um degrau muito grande, porque isso, essa questão, vamos dizer assim, ela está também nas pequenas coisas, se você causa um degrau muito grande, fica parecendo que o feminicídio é muito excepcional, só para alguns. Daí um espectador, macho desconstruído, pode ficar tranquilo, com a certeza que está livre dessa (risos). Então eu acho que um figurino que permite esse trânsito sem um degrau muito chocante, ele facilita esse trânsito, traz essa comunicação meio a reboque (não sei se reboque é uma boa palavra). 
E. - Sim... Pra gente encerrar, queria te agradecer imensamente pelo seu tempo! Qualquer outra coisa, nos falamos mais!

Verônica Fabrini - Ah sim, qualquer coisa, do texto ou da produção, vamos nos falando. Foi bem importante pensar sobre o processo. 